Review

\title{
Toxin-Based Therapeutic Approaches
}

\section{Assaf Shapira and Itai Benhar *}

Department of Molecular Microbiology and Biotechnology, The George S. Wise Faculty of Life Sciences, Tel Aviv University, Ramat Aviv 69978, Israel; E-Mail: assafsha@yahoo.com

* Author to whom correspondence should be addressed; E-Mail: benhar@post.tau.ac.il; Tel.: 972-3-6407511; Fax: 972-3-6409407.

Received: 14 October 2010; in revised form: 25 October 2010 / Accepted: 26 October 2010 / Published: 28 October 2010

\begin{abstract}
Protein toxins confer a defense against predation/grazing or a superior pathogenic competence upon the producing organism. Such toxins have been perfected through evolution in poisonous animals/plants and pathogenic bacteria. Over the past five decades, a lot of effort has been invested in studying their mechanism of action, the way they contribute to pathogenicity and in the development of antidotes that neutralize their action. In parallel, many research groups turned to explore the pharmaceutical potential of such toxins when they are used to efficiently impair essential cellular processes and/or damage the integrity of their target cells. The following review summarizes major advances in the field of toxin based therapeutics and offers a comprehensive description of the mode of action of each applied toxin.
\end{abstract}

Keywords: toxins; targeting; pseudomonas exotoxin A; diphtheria toxin; ricin; anthrax; immunotoxins; suicide gene

\section{Introduction}

The secretion of polypeptides by prokaryotic and eukaryotic cells is an elaborate mechanism enabling the execution of essential processes like active modulation of the environment, enzymatic processing of nutrients and communication with other cells. However, a unique group of secreted polypeptides, the secreted toxins, plays a different role in maintaining the fitness of the organism, and have been perfected through evolution with the aim of damaging other living organisms. As such, toxins provide their producer with advantages such as enhanced defense capabilities or pathogenic 
competence. Most natural protein toxins can be divided into three major groups: 1 . Toxins that damage the cell by disrupting membrane integrity; 2 . Toxins that disrupt the normal electrical activity of the nervous system of the intoxicated organism; 3 . Toxins that disrupt or interfere with cellular processes by virtue of an enzymatic activity. Members of groups 1 and 2 may affect the target cells by enzymatic or non-enzymatic activities. Some members of the third group, on which this review is focused, are extremely toxic polypeptides that have the capability of self translocation into the cell cytoplasm where they execute their activity that, in most cases, leads to death of the intoxicated cell. Scientific advances in the last decades facilitated the processing and manipulation of biological substances; among which are toxic polypeptides and their encoding genes. By using different strategies for directing toxic moieties to diseased cells/tissues (Figure 1), scientists have established a new niche in clinical research, called "toxin-based therapy".

Figure 1. Three targeting strategies in toxin based therapy. Ligand targeted toxins: a ligand (antibody, antibody derivative, cytokine, etc.), which specifically binds to a disease related cell-surface antigen/receptor is linked to a toxic moiety, preferentially as a replacement to the natural cell binding domain of that toxin. Upon administration to patients, the construct selectively binds, is internalized and intoxicates diseased cells, sparing healthy cells that do not display the target on their surface. Protease activated toxins: the toxin is engineered to be cleaved and activated by a disease-related intracellular or extracellular protease. Toxin cleavage may enhance cell-binding and/or translocation, stabilization or catalytic activity of the toxic moiety specifically in protease expressing cells, leading to their eradication. Toxin based suicide gene therapy: a DNA construct, encoding for a toxic polypeptide whose expression is regulated by a specific transcription regulation element (TRE), is delivered to a heterogeneous cell population. However, intoxication occurs only in diseased cells that express an active disease-associated transcription factor (DATF) that specifically binds to the TRE and activates the transcription machinery (RP: RNA polymerase).

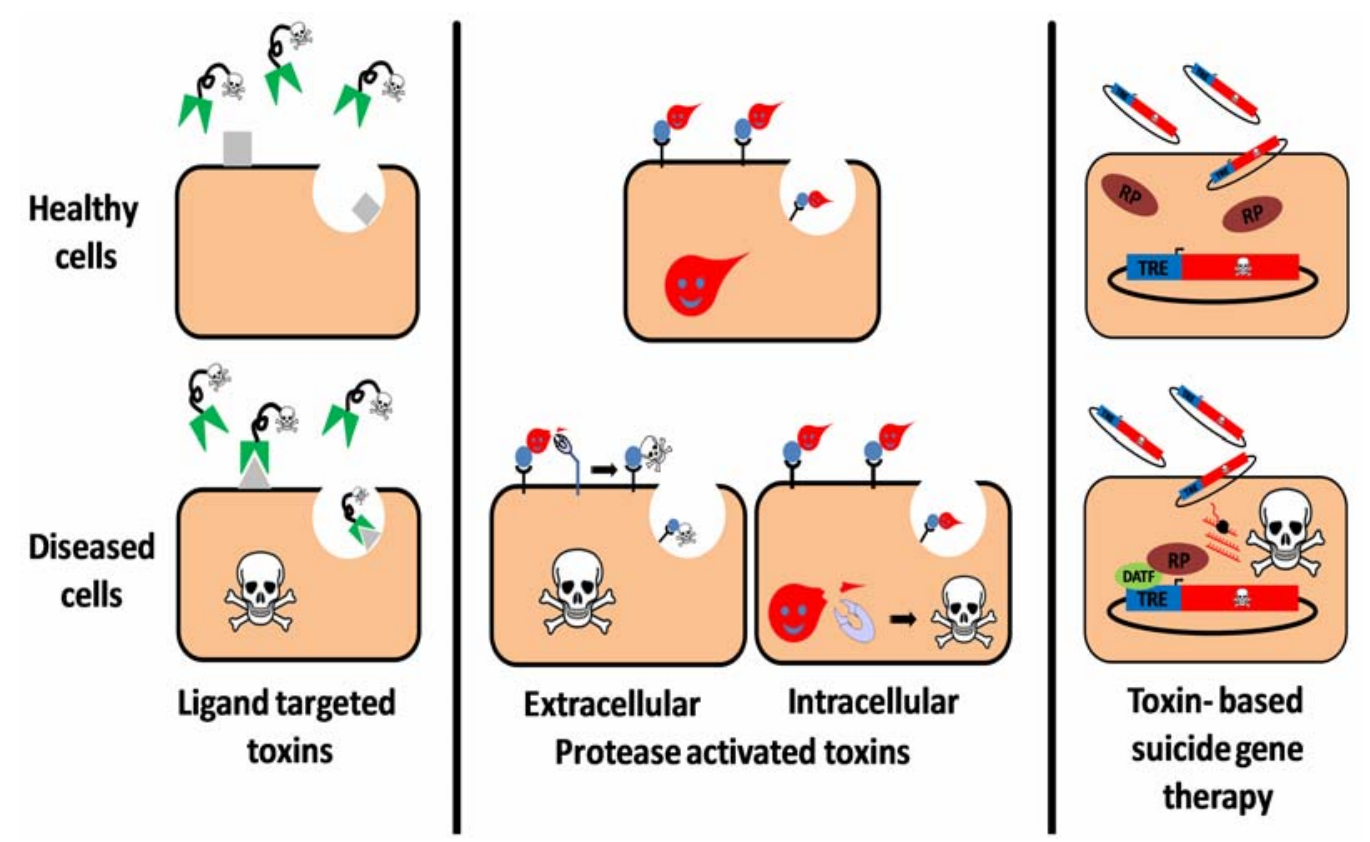


The following review provides highlights of several prominent studies in this field; products from some of these studies have been evaluated clinically, or are currently undergoing clinical evaluation, mostly in context of oncological diseases. Constructs were classified by the targeting strategy used, namely surface antigen/receptor specific targeting (immunotoxins), transcriptional targeting (suicide genes) and protease specific targeting (Protease activated toxins). Emphasis has been put on constructs in which the toxic moiety is a derivative of the bacterial toxins produced by Corynebacterium diphtheria (Diphtheria toxin), Pseudomonas aeruginosa (Pseudomonas exotoxin A) and Bacillus anthrachis (Anthrax toxin); or plant produced toxins (ribosome inactivating proteins). For recent reviews about the botulinum toxin, a bacterial neurotoxin which is commonly applied in today's medicine and is not covered in the following pages, see [1-4].

\section{Ligand Targeted Toxins-Immunotoxins}

The term "immunotoxin" classically refers to molecules which consist of a protein toxin linked to a targeting moiety derived from the immune system (such as an antibody or an antibody fragment); but frequently expanded to include other target-specifying ligands (such as a cytokine). The idea of development of a "magic bullet" that has a specific attraction to a disease-causing target, avoiding healthy body cells, was originally suggested by Paul Ehrlich over 100 years ago [5-7]. However, it was only in the 1970s that therapeutic agents composed of toxins conjugated to antibodies against cell surface antigens were shown to kill tumor cells $[8,9]$. Since then, many hybrid molecules consisting of a toxin coupled with a specific targeting antibody/ligand were developed; most of them are targeted against tumor cells [10] (Figure 1).

First generation immunotoxins were prepared by chemically conjugating antibodies to natural-intact toxin units or to toxins with attenuated cell binding capability. However, these constructs were heterogeneous and unspecific because of the multiplicity of potential sites available for chemical conjugation and as the presence of the cell binding domain of the toxin led to intoxication of "normal" cells, respectively. Immunotoxins of the second generation were also based on chemical conjugation between the targeting moiety and the toxin. Nevertheless, cumulative knowledge on the structure and function of the toxins enabled the removal of their native non-specific cell binding domain, generating much more target-specific immunotoxins when conjugated to monoclonal antibodies. Although more specific, and thus better tolerated by animals, immunotoxins from the second generation were still chemically heterogeneous and their large size hindered them from penetrating solid tumors. In order to avoid heterogeneity, improve tumor penetration and reduce production complexity and costs, recombinant DNA techniques were applied in the production of third generation immunotoxins. In these constructs, which are mostly produced in the bacterium Escherichia coli, the cell binding domain of the toxin is genetically replaced with a ligand or with the Fv portion of an antibody in which its light and heavy chain variable fragments are either genetically linked (scFv) or held together by a disulfide bond (dsFv) (Figure 2).

Among the bacterial toxins that were used for the construction of immunotoxins, the most common are diphtheria toxin and pseudomonas exotoxin A, which are naturally produced by the Gram-positive, aerobic Corynebacterium diphtheria and by the Gram-negative, aerobic Pseudomonas aeruginosa, respectively. Plant derived toxins, which belong to a group of toxins denoted "ribosome inactivating 
proteins" (RIPs), were also used in the preparation of immunotoxins. Among them, ricin, saporin and pokeweed antiviral protein (PAP), produced by Ricinus communis, Saponaria officinalis and Phytolacca americana, respectively, were most commonly used. All of these toxins are extremely potent and exert their toxicity by enzymatically inhibiting the protein synthesis machinery of eukaryotic cells (for additional reviews on immunotoxins, see [10-16]).

Figure 2. Three generations of immunotoxins. First generation immunotoxins were prepared by chemically conjugating antibodies/ligands to intact toxin units or to toxins with attenuated cell binding capability. Reducible or non-reducible chemical bonds/linkers were used for that purpose; the first was generally applied when the conjugation site was positioned on part of the toxin that translocates to the cytosol. In second generation immunotoxins, truncated toxins that lack a cell binding domain were chemically conjugated to a targeting moiety. In third generation immunotoxins, mostly produced in the bacterium Escherichia coli, the cell binding domain of the toxin is genetically replaced with a ligand or with the Fv portion of an antibody in which the light and heavy chain variable fragments are either genetically linked ( $\mathrm{scFv}$ ) or held together by a disulfide bond (dsFv).

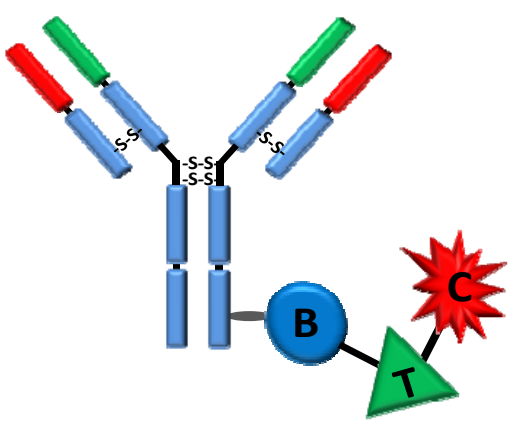

First generation

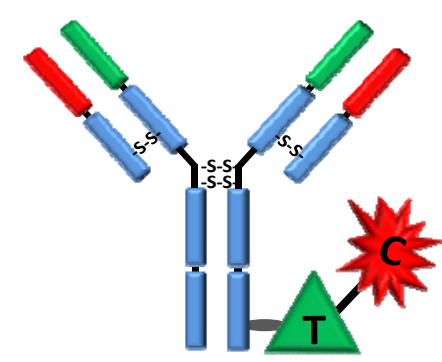

Second generation

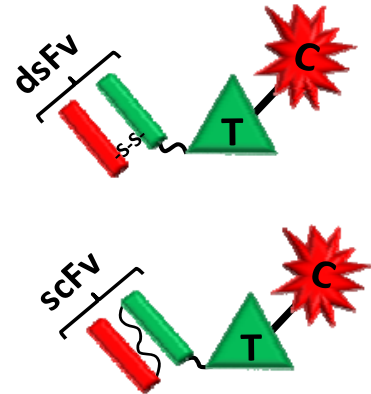

Third generation

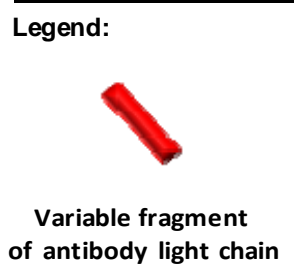

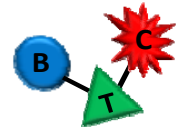

Hypothetical toxin which composed of binding (B), translocation (T) and catalytic (C) domains
Reducible or non-reducible chemical linker

In the next chapter, selected immunotoxins will be classified by their toxic moiety (diphtheria toxin, pseudomonas exotoxin A or RIPs derivatives), and a short review on the mechanism of action of their coupled toxins will be followed by a brief description of their disease-causing target, targeting antibody/ligand, and current status of clinical trials. Information about these and other clinically evaluated immunotoxins is summarized in Table 1. For ligand targeted toxins, we provide detailed examples of toxin based therapies that were evaluated in patients and do not detail the hundreds of examples of molecules that were evaluated pre-clinically. 
Table 1. Clinically evaluated/under evaluation immunotoxins.

\begin{tabular}{|c|c|c|c|c|c|c|c|}
\hline $\begin{array}{l}\text { Construct } \\
\text { Name }\end{array}$ & $\begin{array}{c}\text { Targeting } \\
\text { Moiety }\end{array}$ & $\begin{array}{c}\text { Toxic } \\
\text { Moiety }\end{array}$ & $\begin{array}{l}\text { Toxin } \\
\text { Source }\end{array}$ & Target & Indication & $\begin{array}{c}\text { Clinical } \\
\text { Trial } \\
\text { Phase } \\
\end{array}$ & References \\
\hline $\begin{array}{c}\text { DAB }_{389 I L 2} \\
\text { (Denileukin } \\
\text { Diftitox) }\end{array}$ & IL-2 & $\mathrm{DAB}_{389}$ & DT & IL-2R & $\begin{array}{c}\text { CTCL,NHL, CLL, } \\
\text { NSCLC, GVHD, psoriasis, } \\
\text { melanoma, ovarian, breast, } \\
\text { kidney cancers }\end{array}$ & $\begin{array}{c}\text { I,II,III,IV } \\
\text { *FDA } \\
\text { approved } \\
\text { For } \\
\text { CTCL } \\
\text { treatment }\end{array}$ & {$[17-25]$} \\
\hline $\mathrm{DAB}_{486} \mathrm{IL2}$ & IL-2 & $\mathrm{DAB}_{486}$ & DT & IL-2R & $\begin{array}{l}\text { NHL,HD,CLL, } \\
\text { CTCL,KS,RA }\end{array}$ & $\mathrm{I} / \mathrm{II}$ & [26-31] \\
\hline $\begin{array}{l}\text { Tf-CRM107 } \\
\text { (TransMID) }\end{array}$ & Transferrin & CRM107 & DT & TfR & Brain and CNS tumors & I, III & {$[32-34]$} \\
\hline DT388-GM-CSF & GM-CSF & $\mathrm{DT}_{388}$ & DT & GM-CSFR & AML & $\mathrm{I}$ & {$[35]$} \\
\hline $\mathbf{D A B}_{389} \mathrm{EGF}$ & EGF & $\mathrm{DAB}_{389}$ & DT & EGFR & $\begin{array}{l}\text { EGFR-expressing } \\
\text { carcinoma }\end{array}$ & $\mathrm{I} / \mathrm{II}$ & [11] \\
\hline $\begin{array}{c}\text { A-dmDT390- } \\
\text { bisFV (UCHT1) }\end{array}$ & bisFv & $\mathrm{DT}_{390}$ & DT & $\mathrm{CD} 3 \varepsilon$ & T-cell lymphoma/leukemia & $\mathrm{I} / \mathrm{II}$ & {$[36,37]$} \\
\hline DT388-IL3 & $\begin{array}{l}\text { Variant } \\
\text { IL-3 }\end{array}$ & $\mathrm{DT}_{388}$ & DT & IL-3R & AML, MDS & $\mathrm{I} / \mathrm{II}$ & {$[38]$} \\
\hline OVB3-PE & MAb & Full length PE & $\mathrm{PE}$ & $\begin{array}{l}\text { Ovarian } \\
\text { antigen }\end{array}$ & Ovarian cancer & I & [39] \\
\hline ERB-38 & $\mathrm{dsFv}$ & PE38 & PE & $\begin{array}{l}\text { erbB2/ } \\
\text { HER2 }\end{array}$ & Breast, esophageal cancers & I & [40] \\
\hline $\begin{array}{l}\text { SS1(dsFv)PE38 } \\
\text { (SS1P) }\end{array}$ & $\mathrm{dsFv}$ & PE38 & $\mathrm{PE}$ & Mesothelin & $\begin{array}{l}\text { Mesothelioma, ovarian, } \\
\text { pancreatic cancers }\end{array}$ & I & {$[41,42]$} \\
\hline $\begin{array}{c}\text { B3(Fv)-PE38 } \\
\text { (LMB-7) }\end{array}$ & $\mathrm{scFv}$ & PE38 & $\mathrm{PE}$ & Lewis $\mathrm{Y}$ & Adenocarcinoma & I & {$[10]$} \\
\hline LMB-1 & MAb & PE38 & $\mathrm{PE}$ & Lewis Y & Adenocarcinoma & I & {$[43]$} \\
\hline $\begin{array}{c}\text { RFB4(dsFv)- } \\
\text { PE38 } \\
\text { (BL22/CAT3888) } \\
\end{array}$ & $\mathrm{dsFv}$ & PE38 & PE & $\mathrm{CD} 22$ & NHL,CLL,HCL, ALL & $\mathrm{I}, \mathrm{II}$ & [44-47] \\
\hline LMB-2 & $\mathrm{scFv}$ & PE38 & $\mathrm{PE}$ & $\mathrm{CD} 25$ & Leukemia, lymphoma & II & {$[48]$} \\
\hline $\operatorname{scFv}($ FRP5)-ETA & $\mathrm{scFv}$ & PE40 & PE & $\begin{array}{l}\text { erbB2 } \\
\text { /HER2 }\end{array}$ & $\begin{array}{c}\text { Melanoma, Breast, colon } \\
\text { cancers }\end{array}$ & I & {$[49,50]$} \\
\hline TP40 & TGF $\alpha$ & Modified PE40 & $\mathrm{PE}$ & EGFR & Bladder cancer & $\mathrm{I}$ & [51] \\
\hline TP38 & TGF $\alpha$ & PE38 & $\mathrm{PE}$ & EGFR & Glioblastoma & II & {$[52-54]$} \\
\hline $\begin{array}{c}\text { BR96sFv-PE40 } \\
\text { (SGN-10) }\end{array}$ & $\mathrm{scFv}$ & PE40 & $\mathrm{PE}$ & Lewis $\mathrm{Y}$ & Adenocarcinoma & I & [55] \\
\hline $\begin{array}{c}\text { B3(dsFv)-PE38 } \\
\text { (LMB-9) }\end{array}$ & $\mathrm{dsFv}$ & PE38 & $\mathrm{PE}$ & Lewis Y & Adenocarcinoma & I & [10] \\
\hline $\begin{array}{c}\text { IL4(38-37) } \\
\text { PE38KDEL } \\
\text { (NBI-3001) }\end{array}$ & $\begin{array}{c}\text { Circularly } \\
\text { permuted } \\
\text { IL-4 }\end{array}$ & Modified PE38 & $\mathrm{PE}$ & IL-4R & $\begin{array}{l}\text { Brain, CNS, kidney, lung, } \\
\text { breast cancers }\end{array}$ & $\mathrm{I}, \mathrm{II}$ & {$[56-58]$} \\
\hline
\end{tabular}


Table 1. Cont.

\begin{tabular}{|c|c|c|c|c|c|c|c|}
\hline $\begin{array}{l}\text { Construct } \\
\text { Name }\end{array}$ & $\begin{array}{c}\text { Targeting } \\
\text { Moiety }\end{array}$ & $\begin{array}{c}\text { Toxic } \\
\text { Moiety }\end{array}$ & $\begin{array}{l}\text { Toxin } \\
\text { Source }\end{array}$ & Target & Indication & $\begin{array}{c}\text { Clinical } \\
\text { Trial } \\
\text { Phase }\end{array}$ & References \\
\hline $\begin{array}{c}\text { Mutated } \\
\text { RFB4(dsFv)- } \\
\text { PE38 } \\
\text { (HA22/CAT- } \\
\text { 8015) } \\
\end{array}$ & $\mathrm{dsFv}$ & PE38 & $\mathrm{PE}$ & $\mathrm{CD} 22$ & $\begin{array}{c}\text { HCL, ALL, NHL CLL, } \\
\text { PLL, SLL }\end{array}$ & I & {$[59,60]$} \\
\hline $\begin{array}{l}\text { IL13-PE38QQR } \\
\text { (cinterdekin } \\
\text { besudotox) }\end{array}$ & IL-13 & Modified PE38 & $\mathrm{PE}$ & IL-13R & Glioma & I/II, III & {$[61-64]$} \\
\hline RFB4-Fab'-dgA & Fab' & $\begin{array}{c}\text { Deglycosylated } \\
\text { RTA } \\
\end{array}$ & Ricin & $\mathrm{CD} 22$ & B-NHL & I & {$[65]$} \\
\hline $\begin{array}{c}\text { RFB4-dgA } \\
\text { (IMTOX-22) }\end{array}$ & $\mathrm{MAb}$ & $\begin{array}{c}\text { Deglycosylated } \\
\text { RTA } \\
\end{array}$ & Ricin & $\mathrm{CD} 22$ & B-NHL, CLL & I & {$[66,67]$} \\
\hline $\begin{array}{c}\text { HD37-dgA } \\
\text { (IMTOX-19) }\end{array}$ & $\mathrm{MAb}$ & $\begin{array}{c}\text { Deglycosylated } \\
\text { RTA } \\
\end{array}$ & Ricin & CD19 & NHL & $\mathrm{I}$ & {$[68,69]$} \\
\hline $\begin{array}{l}\text { RFB4-dgA + } \\
\text { HD37-dgA } \\
\text { (Combotox) }\end{array}$ & $\mathrm{MAb}$ & $\begin{array}{l}\text { Deglycosylated } \\
\text { RTA }\end{array}$ & Ricin & $\begin{array}{l}\text { CD22, } \\
\text { CD19 }\end{array}$ & NHL, ALL & I & {$[70,71]$} \\
\hline $\begin{array}{c}\text { RFT5-dgA } \\
\text { (IMTOX-25) }\end{array}$ & MAb & $\begin{array}{c}\text { Deglycosylated } \\
\text { RTA } \\
\end{array}$ & Ricin & $\mathrm{CD} 25$ & $\begin{array}{c}\text { HD, CTCL, melanoma, } \\
\text { GVHD }\end{array}$ & $\mathrm{I}, \mathrm{II}$ & {$[72-76]$} \\
\hline Ki-4.dgA & $\mathrm{MAb}$ & $\begin{array}{c}\text { Deglycosylated } \\
\text { RTA } \\
\end{array}$ & Ricin & CD30 & $\mathrm{HD}, \mathrm{NHL}$ & I & {$[75,77]$} \\
\hline Anti-B4-bR & $\mathrm{MAb}$ & Blocked ricin & Ricin & CD19 & B-NHL & II & {$[78-81]$} \\
\hline Anti-CEA-bR & $\mathrm{MAb}$ & Blocked ricin & Ricin & CEA & Colorectal cancer & $\mathrm{I} / \mathrm{II}$ & [82] \\
\hline N901-bR & MAb & Blocked ricin & Ricin & CD56 & SCLC & $\mathrm{I}$ & {$[83-85]$} \\
\hline $\begin{array}{c}\text { Anti-CD7-dgA } \\
\text { (DA7) }\end{array}$ & MAb & $\begin{array}{c}\text { Deglycosylated } \\
\text { RTA } \\
\end{array}$ & Ricin & CD7 & T-NHL & I & {$[86]$} \\
\hline $\begin{array}{l}\text { Anti-CD3-dgA } \\
+ \text { Anti-CD7-dgA } \\
\end{array}$ & MAb & $\begin{array}{c}\text { Deglycosylated } \\
\text { RTA } \\
\end{array}$ & Ricin & $\mathrm{CD} 3, \mathrm{CD} 7$ & GVHD & $\mathrm{I} / \mathrm{II}$ & {$[87]$} \\
\hline $\begin{array}{c}\text { CD5-IC, CD5 } \\
\text { Plus } \\
\end{array}$ & $\mathrm{MAb}$ & RTA & Ricin & CD5 & RA, SLE, diabetes mellitus & I,II & [88-92] \\
\hline H65-RTA & MAb & RTA & Ricin & CD5 & CTCL, GVHD & $\mathrm{I}, \mathrm{I} / \mathrm{II}$ & [93-95] \\
\hline T101-RTA & $\mathrm{MAb}$ & RTA & Ricin & CD5 & CLL & $\mathrm{I}$ & [96-98] \\
\hline MDX-RA & $\mathrm{MAb}$ & RTA & Ricin & $\begin{array}{l}\text { Human } \\
\text { lens } \\
\text { epithelial } \\
\text { antigen }\end{array}$ & $\begin{array}{c}\text { Posterior capsule } \\
\text { opacification (secondary } \\
\text { cataract) }\end{array}$ & III & {$[99-101]$} \\
\hline $\begin{array}{l}\text { XomaZyme-Mel } \\
\text { (XMMME-001- } \\
\text { RTA) }\end{array}$ & MAb & RTA & Ricin & $\begin{array}{c}\text { Melanoma } \\
\text { antigen }\end{array}$ & Melanoma & $\mathrm{I} / \mathrm{II}$ & {$[102-107]$} \\
\hline $\begin{array}{c}\text { XomaZyme-791 } \\
\text { (79IT/36-RTA) }\end{array}$ & MAb & RTA & Ricin & $\begin{array}{l}72 \mathrm{kDa} \\
\mathrm{TAA}\end{array}$ & Colorectal cancer & I & [108-110] \\
\hline 454A12-rRA & $\mathrm{MAb}$ & RTA & Ricin & TfR & Leptomeningeal neoplasia & $\mathrm{I}$ & {$[111]$} \\
\hline
\end{tabular}


Table 1. Cont.

\begin{tabular}{|c|c|c|c|c|c|c|c|}
\hline $\begin{array}{c}\text { Construct } \\
\text { Name }\end{array}$ & $\begin{array}{c}\text { Targeting } \\
\text { Moiety }\end{array}$ & $\begin{array}{c}\text { Toxic } \\
\text { Moiety }\end{array}$ & $\begin{array}{l}\text { Toxin } \\
\text { Source }\end{array}$ & Target & Indication & $\begin{array}{c}\text { Clinical } \\
\text { Trial } \\
\text { Phase }\end{array}$ & References \\
\hline 260F9-rRTA & MAb & RTA & Ricin & $\begin{array}{c}55 \mathrm{kDa} \\
\text { breast } \\
\text { cancer } \\
\text { antigen }\end{array}$ & Breast cancer & I & {$[112,113]$} \\
\hline B43-PAP & $\mathrm{MAb}$ & PAP & PAP & CD19 & ALL & I & [114] \\
\hline TXU-PAP & $\mathrm{MAb}$ & PAP & PAP & CD7 & HIV-1 infection & I & [115] \\
\hline BER-H2-Sap6 & $\mathrm{MAb}$ & Saporin & Saporin & CD30 & HD & I & [116] \\
\hline HUM-195/rGel & $\mathrm{MAb}$ & Gelonin & Gelonin & CD33 & AML,CML & I & {$[117]$} \\
\hline BDI-1-MD & MAb & Momordin & Momordin & $\begin{array}{c}\text { Bladder } \\
\text { carcinoma } \\
\text { antigen }\end{array}$ & Bladder cancer & I & {$[118]$} \\
\hline
\end{tabular}

Abbreviations: MAb: monoclonal antibody; dsFv: disulfide-stabilized Fv antibody fragment; scFv: A singlechain (genetically linked) variable fragment; bisFv: two Fv fragments connected via a disulfide bond; Fab': fragment antigen-binding (one constant / one variable domain of each heavy and light chain connected by a disulfide bond); IL(R): interleukin (receptor); DT: diphtheria toxin; $\mathrm{DAB}_{389}, \mathrm{DAB}_{486}, \mathrm{DT}_{388}, \mathrm{DT}_{390}$ : truncated forms of DT that lack receptor-binding activity; CRM107: a mutated full-length diphtheria toxin that lack receptor-binding activity; PE: pseudomonas exotoxin A; PE38, PE40: truncated forms of PE that lack the receptor-binding domain Ia; RTA: ricin toxin A; HIV: human immunodeficiency virus; CTCL: cutaneous T cell lymphoma; NHL: non-Hodgkin's lymphoma; MDS: myelodysplastic syndrome; ALL: acute lymphoblastic leukemia; SLL: small lymphocytic lymphoma; GVHD: graft versus host disease; CNS: central nervous system; EGF(R): epidermal growth factor (receptor); TGF(R): transforming growth factor (receptor) AML: acute myelogenous leukemia; CML: chronic myelogenous leukemia; CLL: chronic lymphocytic leukemia; HD: Hodgkin's disease; HCL: hairy cell leukemia; PLL: prolymphocytic leukemia; (N)SCLC: (non) small cell lung cancer; TAA: tumor associated antigen; TfR: transferrin receptor; CSF: cerebrospinal fluid, PAP: pokeweed antiviral protein; RA: rheumatoid arthritis; SLE: systemic lupus erythematosus.

\subsection{Diphtheria Toxin Based Immunotoxins}

\subsubsection{Diphtheria Toxin-Mechanism of Action}

Diphtheria toxin (DT), secreted by pathogenic strains of the bacterium Corynebacterium diphtheria, is the prototype for the family of ADP-ribosylating toxins. It belongs to a group of toxins called $\mathrm{AB}$ toxins that consist of two fragments (A and B). The B fragment is responsible for cell entry (binding to a cell surface receptor and subsequent translocation into the cell cytoplasm) while the internalized A fragment intoxicates the cell by virtue of its enzymatic activity $[119,120]$. The toxin is secreted as a single protein of 535 amino acids and is composed of three functional domains: the $\mathrm{N}$ terminal domain (residues 1-193) represents the catalytic (C) A fragment/domain (DTA/DT-A). The $\mathrm{C}$ terminal portion of the toxin (amino acids 194-535) represents the B fragment and is divided into two functional domains: the translocation domain (T) (amino acids 202-378) and the receptor binding domain (R) (amino acids 386-535) [121]. The native diphtheria toxin binds, via its $\mathrm{R}$ domain, to heparin binding epidermal growth factor precursor on the cell membrane, where it is cleaved by cell-surface furin or 
furin-like protease $[122,123]$. The di-chain protein that is still linked by a single disulfide bond between cysteine 186 and cysteine 201 is internalized into clathrin coated pits and reaches the lumen of a developing endosome (where furin-mediated cleavage of toxin molecules that escaped cleavage by cell-surface proteases, may occur [122]). Upon endosome acidification, the T domain undergoes a conformational change that leads to exposure of hydrophobic areas that are inserted into the membrane, forming a channel through which the catalytic domain translocates and escapes from the endosome, probably with the aid of cytosolic factors [124-129]. In the cell cytoplasm, the catalytic domain exerts its toxic activity by transferring adenosine di-phosphate-ribose (ADP-ribose) moiety from nicotinamide dinucleotide (NAD) to a modified histidine residue (diphthamide) at position 715 in the eukaryotic translation elongation factor (eEF2). This action results in the inactivation of the latter, inhibition of protein synthesis, and programmed cell death [13,130-133] (Figure 3). It was also reported that delivery of a single molecule of the catalytic domain into the cytosol is sufficient to kill a cell, demonstrating the extreme potency of this bacterial toxin [134].

Figure 3. Main entry route and mechanism of action of diphtheria toxin. 1. The toxin is secreted as one polypeptide which is composed of three functional domains: the $\mathrm{N}$ terminal catalytic domain ((C), also referred to as DTA/DT-A), the translocation domain $(\mathrm{T})$ and the receptor binding domain $(\mathrm{R})$ (see 3D structure (PDB Entry: 1f01). In the left panel, the colors of the subunits correspond to those in the scheme). In addition, a disulfide bond bridges the $\mathrm{C}$ and $\mathrm{T}$ domains; 2 . The toxin binds via its $\mathrm{R}$ domain to a cellular receptor (heparin binding epidermal growth factor precursor); 3. Cell-surface furin protease cleaves the polypeptide chain between the $\mathrm{C}$ and $\mathrm{T}$ domains that remain linked by a disulfide bond; 4. The toxin-receptor complex is internalized into clathrin coated pits; 5. In the lumen of the early endosome (EE), furin protease cleaves toxin molecules that escaped cell-surface cleavage. The $\mathrm{T}$ domain undergoes acidic-induced conformational change, inserted into the endosome membrane and forms a channel through which the catalytic domain can translocate into the cytoplasm where reduction of the interdomain bridging disulfide bond occurs; 6. In the cytoplasm, the catalytic domain inactivates eukaryotic translation elongation factor 2 (eEF2) by ADP-ribosylation, which causes translation inhibition and consequently cell death.
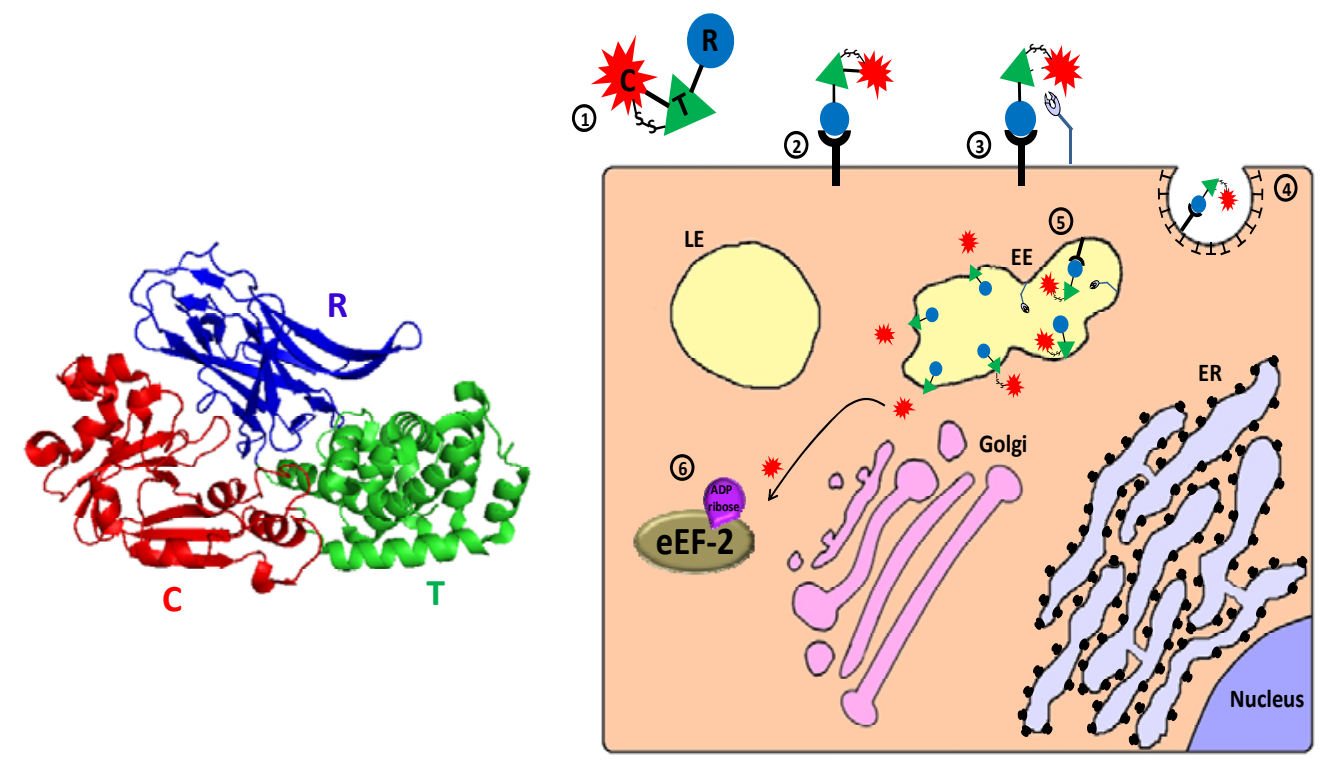


\subsubsection{Targeting IL-2 Receptor: Denileukin Diftitox (Ontak)}

Denileukin Diftitox, which is also named "Ontak" or "DAB389 IL-2", is a fusion protein designed to direct a truncated form of diphtheria toxin to cells that express the high-affinity IL-2 receptor, (consisting of the following subunits: CD25 (IL-2R $\alpha$ ), CD122 (IL-2R $\beta$ ), and CD132 (IL-2R $\gamma$ )), which is present in many different hematologic malignancies like adult $\mathrm{T}$ cell leukemia (ATL), chronic lymphocytic leukemia, Hodgkin's and non-Hodgkin's lymphomas, cutaneous T cell lymphoma (CTCL) and other leukemias and lymphomas [10,135-139]. The immunotoxin is comprised of a genetic fusion between a truncated form of DT (first 388 amino acids, "DAB 389 "), in which the natural receptor binding domain of the toxin was replaced by the cytokine interleukin-2 (IL-2) [140]. Phase I testing was conducted on patients with T-cell lymphoma (CTCL) $(\mathrm{n}=35)$, other non-Hodgkin's lymphomas (NHL) $(=17)$, or Hodgkin's disease (HD) $(n=21)$. The drug, which was administrated by intravenous infusion, produced five complete (CR) and eight partial (PR) remissions in patients with CTCL with one CR and two PR occurring in NHL. No response was documented in patients with HD. The dose-limiting toxicity in these trials was asthenia [141]. In the pivotal phase III trial, 30\% of 71 patients with CTCL treated with Denileukin Diftitox had an objective response (20\% partial response; $10 \%$ complete response) [18]. since the FDA approval of ONTAK as the first immunotoxin for treatment of advanced CTCL in 1999, the drug was tested for treatment of other malignant and non-malignant diseases like B-cell NHL [23], B-cell chronic lymphocytic leukemia (CCL) [19] panniculitic lymphoma [142], psoriasis [17,143] and Graft-versus-host disease (GVHD) [21]. Responses were observed in all of these trials.

\subsubsection{Targeting Granulocyte-Macrophage Colony Stimulating Factor Receptor: DT388-GM-CSF}

The majority of acute myeloid leukemia (AML) blast cells express the granulocyte-macrophage colony-stimulating factor (GM-CSF) receptor [144]. In order to target these cancerous cells, the human GM-CSF was fused to DT388, a truncated DT toxin, replacing its natural receptor binding domain $[145,146]$. The resulting molecule, DT388-GM-CSF (DTGM), was tested on 31 patients who were resistant to chemotherapy. Among them, one had a complete remission and two had partial remissions following treatment with the drug that was administrated by intravenous (i.v.) infusion. Liver failure or transient hepatic encephalopathy were observed in two patients, possibly as a result of inflammatory cytokine release from liver Kupffer cells (DT388-GM-CSF does not directly bind or damage hepatocytes) [35].

\subsubsection{Targeting Transferrin Receptor: Tf-CRM107 (TransMID)}

Transferrin receptors (TfRs) are overexpressed on rapidly dividing cells and various tumor cells. While relatively scarce in healthy brain tissue, intense expression of TfRs can be found on tumor cells of glioblastoma multiforme (GBM's) [147]. Tf-CRM107, which is also called "transMID" is a conjugate protein of a mutant diphtheria toxin that lacks receptor-binding activity (CRM107) [148], linked by a thioester bond to human transferrin (Tf) [149]. In Phase I clinical trials, TF-CRM107 was delivered by high-flow interstitial microinfusion into the tumor region and reduction in tumor volume occurred in nine of 15 patients who could be evaluated, including two complete responses. No 
symptomatic systemic toxicity occurred [32]. In the phase II clinical study, Tf-CRM107 treatment resulted in a 35\% response rate: Of the 34 patients evaluable for efficacy, there were a total of five complete responders and seven partial responders. Infusions of Tf-CRM107 resulted in symptomatic progressive cerebral edema in eight of the total enrolled 44 patients $(14 \%)$ that were responsive to medical management. Seizures were seen in three patients who responded to anticonvulsant therapy [33]. However, a conditional power analysis in phase III determined that Tf-CRM107 was unlikely to improve overall patient survival compared with the current standard of care, and it was decided to terminate the trial and further clinical development of the drug [34].

\subsection{Pseudomonas Exotoxin A Based Immunotoxins}

\subsubsection{Pseudomonas Exotoxin A-Mechanism of Action}

Pseudomonas exotoxin A (abbreviated as PE or ETA) is a 613 amino acid polypeptide secreted by the bacterium Pseudomonas aeruginosa as one of its virulence factors [150]. Like diphtheria toxin, it belongs to the family of ADP-ribosylating toxins [151] and to the group of AB toxins (see description of diphtheria toxin above). The toxin can be divided into three main structural and functional domains: The N-terminal domain Ia (aa 1-252) is responsible for cell recognition. Domain II (aa 253-364) is required for the translocation of the toxin across cellular membranes. The exact function of the structural domain Ib (aa 365-404) is not fully understood. The last four residues (aa 400-404) of domain Ib together with domain III (aa 405-613) form the catalytic subunit of the protein [152,153]. After the C-terminal Lysine 613 is removed by a plasma carboxypeptidase [154], leaving the terminus REDL, the toxin binds via its cell-binding domain Ia to CD91, also called alpha2-macroglobulin receptor/low-density lipoprotein receptor-related protein ( $\alpha 2 \mathrm{MR} / \mathrm{LRP})$, on the surface of the cell [155]. The toxin is then internalized and enters early endosomes mainly via clathrin-coated pits, but also via caveosomes, following association with detergent-resistant microdomains $[155,156]$. In the acidic environment of the endosome, PE dissociates from its receptor, undergoes a conformational change, and is cleaved by the cellular protease furin in a furin-sensitive loop in domain II of the toxin $[123,157,158]$. Following reduction of the single disulfide bond which holds the proteolytic fragments together [159], the enzymatic active C' $37 \mathrm{kDa}$ fragment travel in a Rab9-dependent route to the trans-Golgi network (TGN) [160]. There, its C terminal exposed KDEL-like sequence (REDL) binds the KDEL intracellular sorting receptor and the fragment travels to the endoplasmic reticulum (ER) [161-163]. Alternatively, lipid sorting to the ER may occur [156]. In the ER, sequences in translocation domain II mediates the translocation of the $37 \mathrm{kDa}$ fragment to the cytoplasm in a process that probably involves the subversion of the ER-associated degradation (ERAD) pathway and a retrograde transport via the Sec61p translocon. Escaping, at least in part, from proteosomal degradation may be attributed to the low lysine content of the enzymatically active $\mathrm{C}$ terminal $37 \mathrm{kDa}$ fragment [164-169]. In the cytosol, the APD-ribosylation enzymatic activity of domain III inactivates eEF-2 in a similar way to that of diphtheria toxin (see above), leading to protein synthesis inhibition and programmed cell death [130,132,170-173] (Figure 4). 
Figure 4. Main entry route and mechanism of action of Pseudomonas exotoxin A. 1. The secreted pseudomonas exotoxin A (PE) toxin can be divided into three main structural and functional domains: the $\mathrm{N}$ terminal receptor $(\mathrm{R})$ binding domain $\mathrm{I}$, translocation $(\mathrm{T})$ domain II and the catalytic (C) domain III (see 3D structure (PDB Entry: 1ikq). In the left panel, the colors of the subunits correspond to those in the scheme. For the sake of simplicity, translocation domain II was extended to contain subdomain Ib). A single disulfide bond bridges between cysteines 265 and 287 within domain II; 2. Following removal of a $\mathrm{C}$ terminal lysine residue by plasma carboxipeptidase, the toxin binds to its cell-surface receptor (CD91, also called $\alpha 2 \mathrm{MR} / \mathrm{LRP}$ ); 3 . The toxin is internalized mainly via clathrin-coated pits; 4 . In the early endosome (EE), the toxin undergoes conformational change and is cleaved by the protease furin in a furin sensitive loop, in domain II. The two cleavage products remain linked by the intradomain disulfide bond; 5 . Following reduction of the disulfide bond, the enzymatically active $\mathrm{C}$ terminal fragment, which is composed of domain III and about two thirds of domain II, is routed to the trans-Golgi network where it binds via its $C$ terminally exposed REDL sequence to KDEL receptor and travels to the endoplasmic reticulum (ER); 6. In the ER, sequences in domain II mediate the retro-translocation of the polypeptide via the Sec61p translocon into the cytoplasm; 7. The catalytic domain inactivates eukaryotic translation elongation factor 2 (eEF2) by ADP-ribosylation, which causes translation inhibition and consequently cell death.
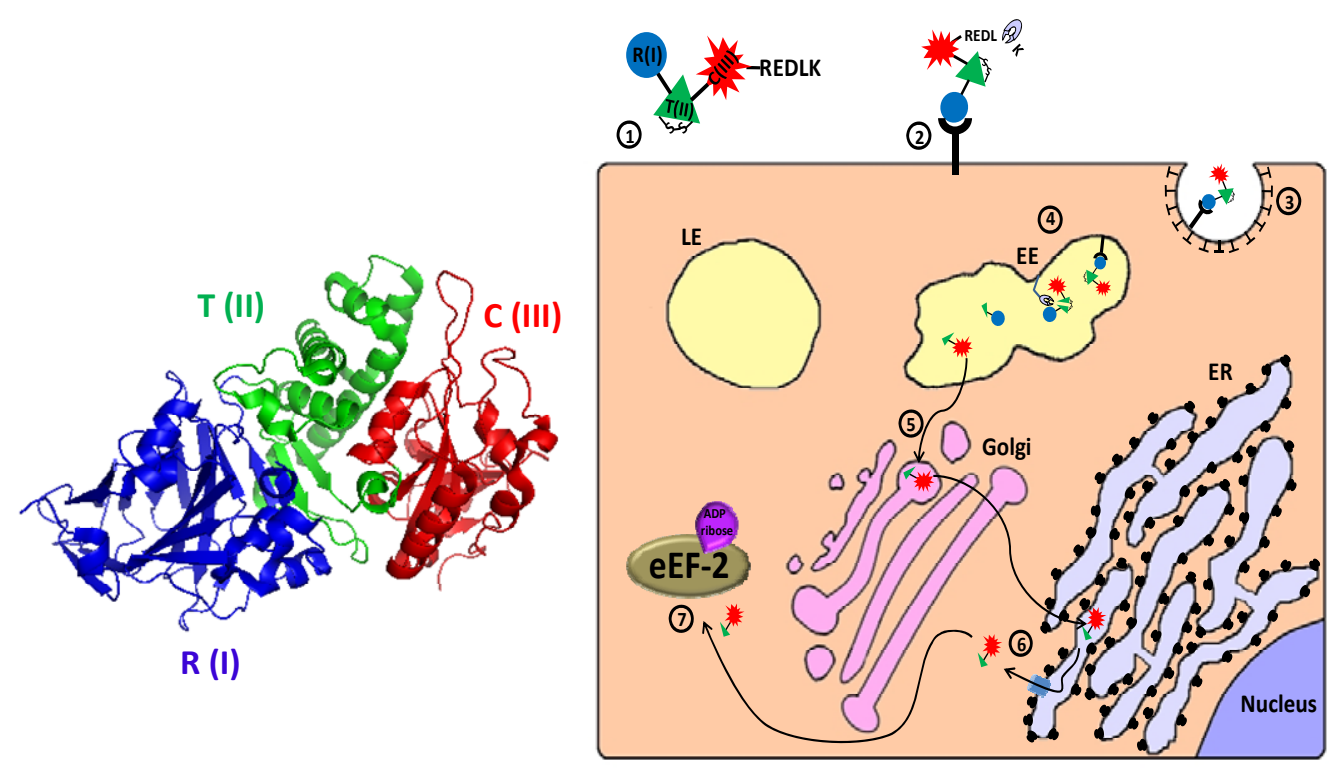

\subsubsection{Targeting the CD25 Subunit of IL2-Receptor: LMB-2}

For the construction of PE-based immunotoxins, the receptor binding domain Ia can be replaced by an antibody, antibody derivative, or a ligand, which preferentially binds to tumor-associated antigen/receptor. The resulting truncated form of PE is designated PE40, indicating its molecular weight $(40 \mathrm{kDa})$. In addition, a large part of domain $\mathrm{Ib}$ can be deleted without effecting cytotoxicity, generating a smaller form of the modified toxin, which is denoted PE38 (38 kDa).

In order to target CD25 expressing cells (low-affinity IL2 receptor, see above) regardless of the presence of other IL2R subunits (CD25 is generally expressed to a much greater extent relative to 
CD122 and CD132 on most malignant cell types [137,138]), PE38 was fused to a single-chain form of the anti-CD25 monoclonal antibody anti-Tac [174-176]. The resulting immunotoxin, Anti-TacFv-PE38 (LMB-2), demonstrated promising results in pre-clinical trials toward CD25 ${ }^{+}$cells and tumor xenografts in nude mice [177-179]. In a Phase I trial, LMB-2 was administrated intravenously to 35 patients with chemotherapy-resistant leukemia, lymphoma and HD, resulting in $1 / 35(3 \%)$ complete and $7 / 35(20 \%)$ partial remissions. The most common toxicities included transaminase elevations that were associated with fever, possibly as an outcome of cytokine release. Six of the 35 patients made neutralizing antibodies after one cycle, preventing them from receiving re-treatment [180-182]. In Phase II trials on patients with metastatic melanoma, administration of LMB-2 has led to a transient partial reduction in circulating and tumor-infiltrating CD25 T-regulatory (Treg) cells which are able to suppress the ability to vaccinate against self/tumor antigens [183]. However, LMB-2 therapy did not augment the immune response to peptide based cancer vaccines [184]. Other Phase II trials are currently underway in patients with CD25 $5^{+}$Chronic Lymphocytic Leukemia (CLL), Cutaneous T cell lymphoma (CTCL) and Hairy Cell Leukemia (HCL).

\subsubsection{Targeting CD22: BL22}

CD22 is a $135-\mathrm{kDa}$ phosphoglycoprotein adhesion molecule present on the surface of B cells, including human B-cell lymphomas and leukemias [185-189]. RFB4(dsFv)-PE38 (BL22) is a stable immunotoxin targeted against CD22 expressing cells, and is composed of disulfide stabilized Fv regions (dsFv) of the anti-CD22 monoclonal antibody RFB4 [190] fused to PE38 [191]. Clinical trials with i.v. administrated BL22 in adults with hairy cell leukemia resistant to purine analogue therapy, produced promising results with 19 complete remissions (61\%) and six partial responses (19\%) in 31 patients in Phase I [45], and 25\% complete remission, 25\% partial response after one cycle of treatment in Phase II $(\mathrm{n}=36)$ [46]. The most common toxicities included hypoalbuminemia, transaminase elevations, fatigue, edema and reversible grade 3 hemolytic uremic syndrome, not requiring plasmapheresis. A recent Phase I clinical trial that was conducted for pediatric subjects with $\mathrm{CD} 22^{+}$ALL and non-Hodgkin lymphoma [47] showed that the treatment was associated with an acceptable safety profile and adverse events were rapidly reversible. No maximum tolerated dose was defined, and although no responses were observed, transient clinical activity was seen in most subjects [192-194].

\subsubsection{Targeting the $\mathrm{Le}^{\mathrm{Y}}$ Antigen: LMB-1}

Lewis $\mathrm{Y}\left(\mathrm{Le}^{\mathrm{Y}}\right)$, a type 2 blood group related oncofetal carbohydrate antigen is expressed on nearly $70 \%$ of human epithelial carcinomas [195-197]. The LMB-1 immunotoxin consists of the anti-Lewis Y monoclonal antibody B3 [198] conjugated to PE38. In a Phase I clinical trial, the immunotoxin was tested on 38 patients with $\mathrm{Le}^{\mathrm{Y}}$ expressing carcinomas of breast, ovarian, colon, esophagus, stomach and ampulla of Vater. A complete remission was observed in a patient with metastatic breast cancer and a greater than $75 \%$ tumor reduction was observed in a colon cancer patient following systemic administration of the immunotoxin. The major toxicity was vascular leak syndrome ascribed to endothelial damage, probably due to binding of the $\mathrm{B} 3$ antibody to $\mathrm{Le}^{\mathrm{Y}}$ antigen which is present in small amounts on endothelial cells [199]. Later developments of Lewis Y targeted 
toxins produced the recombinant immunotoxins B3(Fv)-PE38 (LMB-7), B3(dsFv)-PE38 (LMB-9) and BR96-Fv-PE40 (SGN-10) which were clinically evaluated in patients with Lewis Y-expressing malignancies. However, no significant antitumor activity was observed in these trials $[10,200]$.

\subsection{Ribosome Inactivating Proteins Based Immunotoxins}

\subsubsection{Ribosome Inactivating Proteins-Mechanism of Action}

Ribosome inactivating proteins (RIPs) are a group of glycosylated and non-glycosylated enzymes with $\mathrm{N}$-glycosidase activity that were initially detected in higher plants, but have also been found in fungi, algae and bacteria (for comprehensive reviews, see [201-207]). RIPs may be present in one or more tissues of the plant, and their expression is enhanced in senescence and under various stress conditions [208-214] including microorganisms and viral infections [215-217]. RIPs are artificially divided into three groups on the basis of their structure and mode of activation: type I RIPs are single chain basic proteins of about $30 \mathrm{kDa}$ with enzymatic activity. Some well known members of this group are saporin (from Saponaria officinalis), pokeweed antiviral protein (PAP) (Phytolacca americana) and gelonin (Gelonium multiforum). Type II RIPs, like ricin (from Ricinus communis) and abrin (Abrus precatorius), are heterodimeric proteins consisting of an enzymatically active A chain of about $30 \mathrm{kDa}$ linked through a disulfide bond to a B chain of approximately $35 \mathrm{kDa}$ which has the properties of a lectin. Type III RIPs, like the maize and the barley proteins b-32 and JIP60, respectively, are synthesized as inactive precursors (proRIPs), which lacks a lectin moiety and are activated by proteolytic processing which includes the removal of terminal sequences and a short inhibitory internal peptide [201,206-208,218-220].

Ricin, the prototype of type II RIPs, is a glycosylated heterodimer that binds through its lectin B-chain to galactose or $\mathrm{N}$-acetylgalactosamine residues on glycoproteins and glycolipids which are present on the surface of most eukaryotic cells [221-226]. In addition, certain cells like macrophages and rat liver endothelial cells that express surface mannose receptors were demonstrated to bind ricin also through its own oligosaccharide side chains [227-232]. The cell surface-bound ricin is internalized by clathrin-dependent as well as clathrin-independent endocytosis and travels backward from the Golgi to the ER, where its disulfide linked chains are separated by protein disulfide isomerase. As in the case of PE, ricin is thought to subvert the ERAD pathway, exploiting it for the retrograde transport of the enzymatically active A chain (RTA) into the cell cytosol through the Sec61p translocon. Because of its paucity of lysines, RTA may escape, at least in part, degradation by the proteosome [167,169,233-242] (Figure 5). Type I and type III RIPs lack the cell-binding lectin B chain and are thus generally much less toxic than type II RIPs. However, like ricin, some glycosylated type I RIPs may bind to carbohydrate receptors on the cell surface, and binding of type I RIPs to low density lipoprotein (LDL) receptor related protein ( $\alpha 2 \mathrm{MR} / \mathrm{LRP}$ ), (which also binds PE) has also been demonstrated [243-245]. In addition, coupling type I RIPs (which are equivalent to the enzymatically active A chain of type II RIPs) to a carrier that is capable of binding cells renders the conjugate highly cytotoxic [206,246-249]. The specific mechanism by which type I RIPs gain entry into the cell cytosol remains unclear, but is probably different from that of type II RIPs like ricin: Experiments with the type I RIP, saporin, indicated that it does not rely on Golgi-mediated retrograde transport and ERAD and may involve toxin translocation to the cytoplasm from the endosomes [242,250]. 
Figure 5. Main entry route and mechanism of action of ricin. 1. Ricin toxin is translated as a single glycosylated polypeptide that is composed of a catalytic A domain and a lectin B domain (see 3D structure (PDB Entry: 2aai) in the left panel; the colors of the subunits correspond to those in the scheme). In the producing plant, a small peptide that links the A and $\mathrm{B}$ domains is removed, and the $\mathrm{A}$ and $\mathrm{B}$ chains remain associated via a single disulfide bond; 2. The toxin binds through the lectin B chain to cell-surface galactose or $\mathrm{N}$-acetylgalactosamine residues on glycoproteins and glycolipids; 3. Cell-surface bound ricin is internalized by clathrin-dependent as well as clathrin-independent endocytosis and reaches the early endosome (EE); 4. The toxin travels backward through the Golgi to the endoplasmic reticulum (ER), where its' disulfide linked chains are separated; 5. The catalytic A chain (RTA) is retro-translocated via the Sec61p translocon into the cytoplasm; 6. The catalytically active RTA irreversibly damages ribosome by removing a specific adenine from a conserved 28S rRNA loop ("sarcin/ricin loop"-SRL), which causes translation inhibition and consequently cell death.
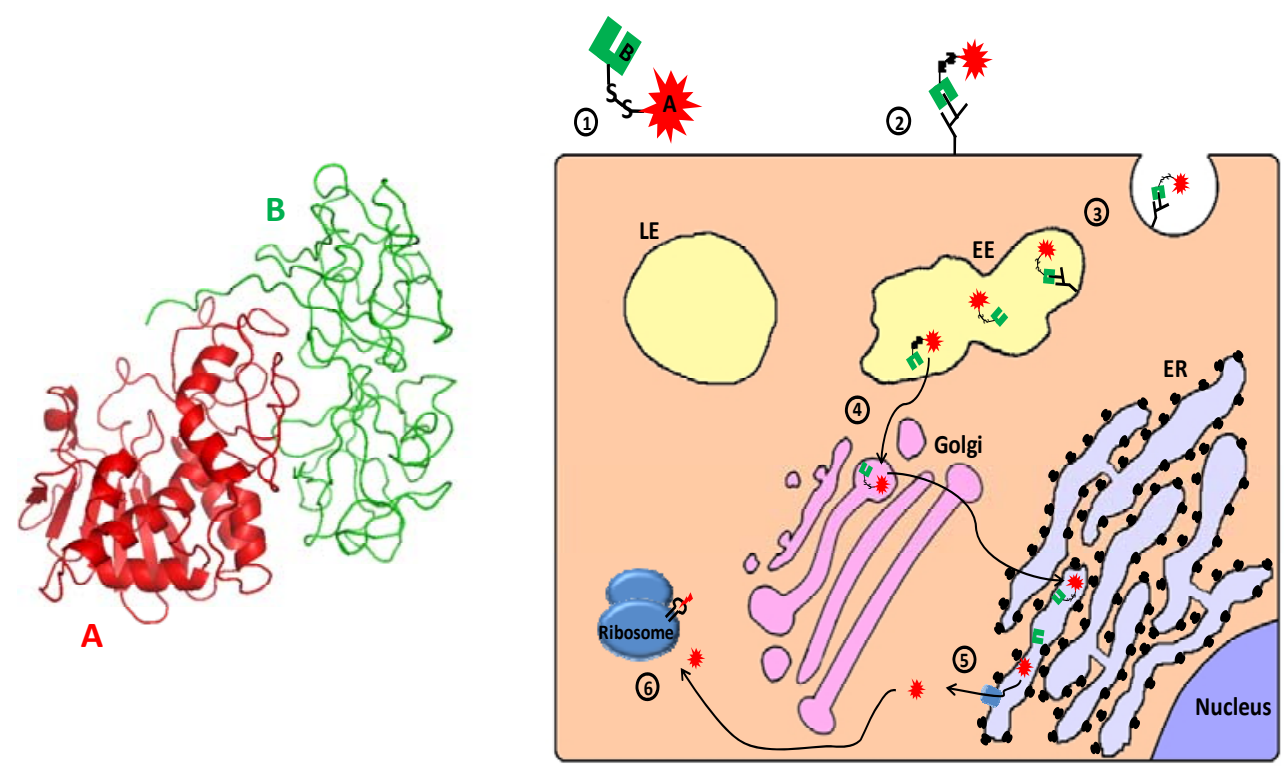

Once in the cytosol, the enzymatic moiety of RIPs irreversibly damages ribosomes by removing a specific adenine (corresponding to residue A4324 in rat 28S rRNA) from a GAGA sequence in a conserved 28S rRNA loop, the so called "sarcin/ricin loop" [251-253]. This modification renders the ribosome unable to interact with elongation factors 2 (eEF2), resulting in inhibition of translation and ultimately apoptotic cell death [201,254-264]. In addition to their classical ribosome-inactivating glycosidase activity, other activities and enzymatic properties were associated with RIPs: antiviral activity [265], depurination of (non-ribosomal) RNA and adenine DNA glycosylase activity [266-270], deoxyribonuclease activity [271-278], ribonuclease activity [279,280], removal of adenine from poly(ADP-ribosyl)ated poly(ADP-ribose) polymerase (an enzyme involved in DNA repair) [281,282], depurination of the capped RNA template [283,284], superoxide dismutase (SOD) activity [285-287] and phospholipase activities [288]. The involvement of these non-classical RIP activities in cytotoxicity is debatable, though accumulating evidence suggests that ribosome inactivation is not the sole means by which RIPs execute their toxic effects [264,289-295]. 


\subsubsection{Targeting CD25 and CD30: RFT5-dgA and ki-4.dgA.}

CD25 and CD30 are lymphoid activation markers which are highly expressed on the surface of Hodgkin's lymphoma cells and only present on a minority of normal human cells [135,296-298]. In order to target these cells, two immunotoxins, RFT5-dgA (IMTOX25) and ki-4.dgA, were constructed. The toxic moiety in these immunotoxins was a chemically deglycosylated form of ricin A chain (dgA) (deglycosylation was demonstrated to minimize nonspecific carbohydrate-receptors mediated uptake of RTA based immunotoxins by reticuloendothelial cells in the liver [299-305]) linked to the targeting moieties RFT5 (anti-CD25) and ki-4 (anti-CD30) monoclonal antibodies, respectively. Phase I/II trials with i.v. administrated RFT5-dgA on 18 patients with refractory Hodgkin's disease (HD), resulted in two partial remissions (PR), one minor response (MR) and five stable diseases (SD) [75]. In a Phase I study of Ki-4-dgA on 15 patients, one PR, one MR and two SD were observed. Dose-limiting toxicities were related to vascular leak syndrome, consisting of edema, tachycardia, dyspnea, weakness and myalgia [75]. A Phase II study evaluating the side effects and efficiency of RFT5-dgA (IMTOX25) treatment in patients with relapsed or refractory cutaneous T-cell non-Hodgkin lymphoma (CTCL) was completed recently, and the immunotoxin is currently evaluated as a treatment for metastatic melanoma (http://clinicaltrials.gov/).

\subsubsection{Targeting CD22 and CD19: RFB4-dgA and HD37-dgA}

CD22 and CD19 are cell surface glycoproteins expressed on normal and malignant B cells [306-309]. For targeting B-cell lymphoma cells, the anti CD22 monoclonal antibody RFB4 [190,310] and the anti CD19 monoclonal antibody HD37 [311] were conjugated to dgA. In a Phase I clinical trial with the immunotoxin RFB4-dgA (IMTOX-22), five of 24 evaluable patients with B-cell lymphoma showed a partial response and one showed a complete response. Similar results were obtained when the drug was administrated as a continuous infusion instead of intermittent bolus [67,312]. Partial and complete responses were also obtained in a Phase I trial on patients with non-Hodgkin's B-cell lymphoma treated with the immunotoxin HD37-dgA (IMTOX-19) [69]. Vascular leak syndrome (VLS) was a common dose-related toxicity in these studies.

\section{Toxin Based Suicide Gene Therapy}

The delivery of genetic material into target cells for the purpose of gaining a therapeutic effect is generally known as "gene therapy" (for review, see [313-323]). Advances in molecular biology, virology and nanotechnology in the past decade enabled the development of a variety of viral and non-viral gene delivery systems [324-326]. When the death of the target cell is the desired therapeutic outcome of the transgene delivery, the process is termed "suicide gene therapy" and involves delivery of genes whose products are either toxic, proapoptotic or have the ability to activate precursors of toxic drugs ("pordrugs") [327-331]. In order to minimize damage to healthy tissue, a specific targeting mechanism must be applied and transcriptional targeting is a very common strategy. The method is based on positioning the suicide gene to be transferred under the transcriptional regulation of a promoter/element which is specifically or at least preferentially active in the target tissue [332-338]. If transcription of a toxin encoding gene is controlled by such a target specific promoter, eradication of undesirable cell population is feasible with minimal collateral damage (Figure 1). The next chapter 
reviews some of the prominent toxin-based suicide gene therapy studies and developments which are classified by their target disease; the majority of them were evaluated at a preclinical level and aimed at cancer therapy. Information about suicide gene constructs developed in these and other studies are summarized in Table 2.

Table 2. Preclinically and clinically evaluated/under evaluation toxin-based suicide genes.

\begin{tabular}{|c|c|c|c|c|c|c|}
\hline Construct Name & \begin{tabular}{|c|} 
Transcription \\
Regulatory Element
\end{tabular} & Toxin & Delivery Vector & Disease & $\begin{array}{c}\text { Clinical } \\
\text { Trial Phase }\end{array}$ & Reference \\
\hline Ad5-PSE/PSA-DT-A & PSA * & DTA & Adenovirus & Prostate cancer & $\begin{array}{l}\text { Preclinical } \\
\text { phase }\end{array}$ & [339] \\
\hline $\begin{array}{c}\text { Ad-PSA/FLP + } \\
\text { Ad- } \\
\text { RSV/FRT2neo/DT-A }\end{array}$ & PSA * & DTA & Adenovirus & Prostate cancer & $\begin{array}{l}\text { Preclinical } \\
\text { phase }\end{array}$ & {$[340]$} \\
\hline C32-PSA/DT-A & $\mathrm{PSA} *$ & DTA & Cationic polymer & Prostate cancer & $\begin{array}{c}\text { Preclinical } \\
\text { phase }\end{array}$ & [341] \\
\hline рТНА-47, рТНА-49 & $\begin{array}{l}\text { hCG }(\alpha \text { or } \beta \\
\text { subunits }) *\end{array}$ & DTA & $\begin{array}{l}\text { Naked DNA- } \\
\text { electroporation }\end{array}$ & Ovarian cancer & $\begin{array}{c}\text { Preclinical } \\
\text { phase }\end{array}$ & [342] \\
\hline $\begin{array}{c}\text { pHE-4/DT-A, } \\
\text { 117-MSLN/DT-A }\end{array}$ & HE4, MSLN * & DTA & Cationic polymer & Ovarian cancer & $\begin{array}{c}\text { Preclinical } \\
\text { phase }\end{array}$ & [343] \\
\hline DTA-H19 (BC-819) & $\mathrm{H} 19$ * & DTA & $\begin{array}{c}\text { Naked DNA, } \\
\text { Cationic polymer }\end{array}$ & $\begin{array}{c}\text { Ovarian, bladder, } \\
\text { pancreatic } \\
\text { cancers }\end{array}$ & I/II, II & [344-346] \\
\hline $\begin{array}{l}\text { DTA-TER, } \\
\text { DTA-TERT }\end{array}$ & hTER,hTERT * & DTA & $\begin{array}{l}\text { Naked DNA- } \\
\text { CaPO4 } \\
\text { precipitate }\end{array}$ & Bladder cancer & $\begin{array}{l}\text { Preclinical } \\
\text { phase }\end{array}$ & [347] \\
\hline HIV-DT-A & $\begin{array}{c}\text { HIV Tat and Rev cis- } \\
\text { acting responsive } \\
\text { sequences }\end{array}$ & DTA & $\begin{array}{l}\text { Retrovirus, } \\
\text { cationic } \\
\text { liposomes }\end{array}$ & HIV-1 infection & $\begin{array}{l}\text { Preclinical } \\
\text { phase }\end{array}$ & [348-350] \\
\hline $\begin{array}{c}\text { pNL-DT } \Delta N-G F P- \\
\text { RRE-SA }\end{array}$ & $\begin{array}{l}\text { HIV Rev cis-acting } \\
\text { responsive sequence }\end{array}$ & $\begin{array}{c}\text { Attenuated } \\
\text { DTA } \\
\text { variant } \\
\end{array}$ & $\begin{array}{c}\text { Non-integrating } \\
\text { lentivirus }\end{array}$ & HIV-1 infection & $\begin{array}{l}\text { Preclinical } \\
\text { phase }\end{array}$ & [351] \\
\hline pA3-6PED & $\begin{array}{c}\text { PAX3 DNA } \\
\text { responsive sequences }\end{array}$ & DTA & $\begin{array}{l}\text { Cationic } \\
\text { liposomes }\end{array}$ & ARMS & $\begin{array}{l}\text { Preclinical } \\
\text { phase }\end{array}$ & {$[352]$} \\
\hline $\begin{array}{l}\text { petbz.ES.DT-A, } \\
\text { pA.E-Sel.DT-A }\end{array}$ & E-selectin * & DTA & $\begin{array}{l}\text { Naked DNA- } \\
\text { electroporation }\end{array}$ & $\begin{array}{c}\text { Activated } \\
\text { endothelial cells } \\
\text { (Angiogenesis) }\end{array}$ & $\begin{array}{l}\text { Preclinical } \\
\text { phase }\end{array}$ & [353] \\
\hline $\begin{array}{c}\text { GH-loxP-DT + CMV- } \\
\text { Cre / GH-Cre }\end{array}$ & $\begin{array}{l}\text { Growth hormone } \\
\qquad(\mathrm{GH}) *\end{array}$ & DTA & Adenovorus & Pituitary Tumor & $\begin{array}{l}\text { Preclinical } \\
\text { phase }\end{array}$ & {$[354]$} \\
\hline BV-CG/ITR-DTA & $\begin{array}{c}\text { GFAP } *+\text { CMV } \\
\text { enhancer }+ \text { ITR of } \\
\text { AAV }\end{array}$ & DTA & Baculovirus & glioma & $\begin{array}{l}\text { Preclinical } \\
\text { phase }\end{array}$ & {$[355]$} \\
\hline $\begin{array}{l}\text { G1CEAPEANa, } \\
\text { G1CEADTANa }\end{array}$ & CEA * & PEA, DTA & $\begin{array}{c}\text { Cationic } \\
\text { liposomes }\end{array}$ & $\begin{array}{l}\text { Colorectal } \\
\text { carcinoma }\end{array}$ & $\begin{array}{l}\text { Preclinical } \\
\text { phase }\end{array}$ & {$[356]$} \\
\hline pRad51-DTA & $\operatorname{Rad} 51 *$ & DTA & $\begin{array}{c}\text { Various } \\
\text { transfection } \\
\text { methods }\end{array}$ & $\begin{array}{c}\text { Variety of cancer } \\
\text { cells }\end{array}$ & $\begin{array}{l}\text { Preclinical } \\
\text { phase }\end{array}$ & [357] \\
\hline
\end{tabular}


Table 2. Cont.

\begin{tabular}{|c|c|c|c|c|c|c|}
\hline Construct Name & $\begin{array}{c}\text { Transcription } \\
\text { Regulatory Element }\end{array}$ & Toxin & Delivery Vector & Disease & $\begin{array}{c}\text { Clinical } \\
\text { Trial Phase }\end{array}$ & Reference \\
\hline $\begin{array}{c}\text { pAF-DTA, } \\
\text { pAF5.1DTA }\end{array}$ & AFP * & DTA & $\begin{array}{c}\text { Cationic } \\
\text { liposomes }\end{array}$ & HCC & $\begin{array}{c}\text { Preclinical } \\
\text { phase }\end{array}$ & {$[358,359]$} \\
\hline pTHA45, pTHA17 & $\begin{array}{c}\text { Immunoglobulin } \\
\text { heavy/k-light chain } *\end{array}$ & DTA & $\begin{array}{c}\text { Naked DNA- } \\
\text { electroporation }\end{array}$ & $\begin{array}{c}\text { B-Lymphoid } \\
\text { Cells }\end{array}$ & $\begin{array}{c}\text { Preclinical } \\
\text { phase }\end{array}$ & {$[360]$} \\
\hline $\begin{array}{c}\text { pTyrIII/DT-A, } \\
\text { pMIA III/DT-A }\end{array}$ & MIA, tyrosinase, $*$ & DTA & Cationic lipids & Melanoma & $\begin{array}{c}\text { Preclinical } \\
\text { phase }\end{array}$ & {$[361]$} \\
\hline $\begin{array}{c}\text { retro-1.3MBPppe } \\
\text { retro-1.3MBPpri }\end{array}$ & MBP * & PE/RTA & Retrovirus & Glioblastoma & $\begin{array}{c}\text { Preclinical } \\
\text { phase }\end{array}$ & {$[362]$} \\
\hline pMSLN/DT-A & MSLN * & DTA & Cationic polymer & Pancreatic cancer & $\begin{array}{c}\text { Preclinical } \\
\text { phase }\end{array}$ & {$[363]$} \\
\hline V3 & $\begin{array}{c}\text { Hsp70B' * HSEs } \\
\text { attenuated } \\
\text { DTA } \\
\text { variants }\end{array}$ & $\begin{array}{c}\text { Cationic } \\
\text { liposomes }\end{array}$ & Pancreatic cancer & $\begin{array}{c}\text { Preclinical } \\
\text { phase }\end{array}$ & {$[364]$} \\
\hline pLTR-DT & $\begin{array}{c}\text { p34 responsive } \\
\text { Lequences (BLV- }\end{array}$ & DTA & $\begin{array}{c}\text { Cationic } \\
\text { LTposomes }\end{array}$ & $\begin{array}{c}\text { BVL infected } \\
\text { cells }\end{array}$ & $\begin{array}{c}\text { Preclinical } \\
\text { phase } \\
\text { (veterinary } \\
\text { use) }\end{array}$ & {$[365,366]$} \\
\hline
\end{tabular}

Abbreviations: DTA/DT-A: the catalytic A fragment of diphtheria toxin; PSA: prostate-specific antigen; hCG: human chorionic gonadotropin; ARMS: alveolar rhabdomyosarcoma; GFAP: glial fibrillary acidic protein; ITR: inverted terminal repeats, AAV: adeno-associated virus; PEA: truncated form of pseudomonas exotoxin A (domains II+III); CEA: human carcinoembryonic antigen; HCC: Hepatocellular carcinoma; hTER: human telomerase RNA, hTERT: human telomerase reverse transcriptase; AFP: human alphafetoprotein; MIA: Melanoma inhibitory activity; MBP: myelin basic protein; MSLN: Mesothelin; HSP: heat shock protein; HSEs: heat shock elements; hCG: human chorionic gonadotropin; CMV: cytomegalovirus; HIV: human immunodeficiency virus; LTR: long terminal repeat; BLV: Bovine leukemia virus. * Refers to the name of the gene/gene product whose transcriptional regulatory elements were used to drive the expression of a toxic gene in target cells.

\subsection{Targeting Prostate Cancer}

Prostate cancer (PCA) is the most common cancer diagnosed in men and a leading cause of cancer deaths [367]. Normal and malignant prostate epithelia specifically express the kallikrein protease prostate-specific antigen (PSA), a serine protease with trypsin- and chymotrypsin-like activities that is responsible for liquifaction of semen [368,369]. PSA gene regulatory regions are prime candidates to direct prostate-specific expression [370-373]. When placed under the transcriptional regulation of the PSA promoter, the diphtheria toxin A chain (DT-A) encoding gene which was delivered by an adenoviral vector showed strong inhibition of tumor growth in a PSA-producing prostate tumor xenograft mouse model while not affecting non-PSA producing tumor xenografts [339]. A PSA promoter-based lentiviral vector has also been used as a mean for DT-A gene delivery, leading to specific eradication of prostate tumor xenografts in nude mice following a single intratumoral injection. Repetitive injections were shown to inhibit the growth of recurrent tumors [374]. 
In another study, a nanoparticulate system based on the cationic poly(b-amino ester)polymer, C32 [375], was used as a DNA delivery system of a suicide gene encoding for a diphtheria toxin A chain (DT-A) under the transcriptional regulation of a prostate-specific modified human PSA promoter, PSE-BC [371]. The genetic material/cationic polymer complex was locally delivered into normal prostate and prostate tumors in mice, causing massive apoptotic prostate cell death, without damaging surrounding tissue [341].

In order to gain tighter control on the expression of the very potent DT-A toxin, Peng et al [340] utilized a dual expression controlling system that relies both on transcriptional regulation and DNA recombination [376-378]. On the basis of their system, the chimeric modified enhancer/promoter sequence of the human prostate-specific antigen (PSA) gene, PSE-BC [371], was used to regulate the expression of the Saccharomyces cerevisiae $2 \mu$ plasmid derived site-directed FLP recombinase. When prostate specific expression of FLP recombinase occurs, site directed DNA recombination that leads to DT-A gene expression takes place. The investigators showed eradication of PSA-expressing normal prostate cells and prostate cancer cells in culture, in xenografts and in a transgenic mouse model following adenoviral delivery of DNA encoding the prostate specific promoter-driven Flp recombinase and the Flp-responsive DT-A gene. Furthermore, Flp recombinase expression was shown to be regulated in a manner that correlates with the amount of PSA expression in these cells [340].

\subsection{Targeting Ovarian Cancer}

Ovarian cancer is a common malignancy in women, and causes more deaths than any other type of female reproductive tract cancer [379]. Lidor et al [342] have demonstrated specific protein synthesis inhibition in malignant ovarian cell lines transfected with plasmids encoding transcriptionally regulated diphtheria DT-A. The toxic gene transcription was regulated by elements of the human chorionic gonadotropin (hCG) promoter, a heterodimeric glycoprotein placental hormone involved in different pregnancy-promoting processes. Although principally produced by trophoblasts, hCG is also expressed in some malignant tumors of the ovary, uterus, testis, colon, liver, pancreas lung, and stomach [380-382].

Targeted expression of DT-A in ovarian cancer cells in vitro and in tumor cells in mouse models was performed by Huang et al [343] using poly(h-amino ester) polymers as a vector for nanoparticulate delivery of DNA. In these ovarian-specific antitumor constructs, the promoters of two genes, HE4 (WFDC2) and MSLN (which transcriptional activity is significantly enhanced in ovarian cancer cells relative to normal ovarian cells and cells in other tissues [383-389]) were chosen to target the expression of DT-A gene to ovarian tumor cells. Significant reduction in tumor mass and a prolonged life span of xenografts bearing mice were observed as a result of DT-A nanoparticles administration directly to subcutaneous xenograft tumors and to the peritoneal cavity. Moreover, treatment with DT-A nanoparticles resulted in more efficient suppression of tumor growth compared to clinically relevant doses of the standard chemotherapeutics cisplatin and paclitaxel, with minimal nonspecific tissue and blood chemistry toxicity [343].

Recently, Mizrahi et al [345] reported the use of transcriptional regulatory sequences of the H19 gene to drive the expression of DT-A specifically in ovarian tumor cells. H19 is a paternally imprinted, maternally expressed, oncofetal gene that encodes an RNA acting as "riboregulator" without a protein product. It is expressed at substantial levels in several different human tumor types, including 
epithelial ovarian cancer [390], but is only marginally or not at all expressed in normal adult tissues [391-399]. Cationic polymer PEI based delivery of DTA-H19 plasmid, encoding the toxic DT-A transcriptionally controlled by regulatory sequences of the H19 gene, showed high killing potential in ovarian cancer cell lines and a significant tumor growth inhibition in animals [345]. In a later case study, DTA-H19 plasmid that was intraperitoneally injected into the peritoneum of a woman with advanced and recurrent ovarian carcinoma has been reported to yield a complete resolution of ascites following several infusions, with minimum adverse events [346]. Phase I/II study of DTA-H19 administered intraperitoneally in subjects with advanced stage ovarian cancer with evidence of symptomatic ascites is currently ongoing.

\subsection{Targeting Bladder Cancer}

Bladder cancer is the second most common urologic malignancy after prostate cancer. It is estimated that bladder cancer will account for 70,530 new cases of cancer and 14,680 cancer-related deaths in the United States during 2010 [400,401]. One of the most crucial enzymes in cell immortality and cancer is telomerase which maintains telomere length stability in almost all cancer cells [402]. Essential conserved core components of the human telomerase include the reverse transcriptase protein family member hTERT and the telomerase RNA hTER [403]. Following in situ hybridization analysis that showed high levels of hTER and hTERT expression in bladder tumors (while no signal was detected in normal tissue), transcription regulatory elements of these two genes were used for targeted gene therapy purpose by driving the expression of the toxic DT-A gene in bladder cancer cells. Experimental data demonstrated that transfection of bladder and hepatocarcinoma cell lines with DT-A expression plasmids under the control of hTER or hTERT regulatory elements resulted in cytotoxicity in accordance with the relative activity of these promoter elements in these cells [347].

In another study, expression of DT-A in subcutaneous injected syngeneic bladder tumor cell lines in mice was driven by the previously described H19 gene regulatory sequence (which is expressed in tumors derived from tissues (such as bladder) that exhibited the gene during embryonic development [404]). Intratumoral injection of the DNA vector as a calcium phosphate precipitate caused a significant suppression of subcutaneous tumor growth, with no obvious toxicity toward the host [405]. Significant suppression of tumor growth in animals and nearly complete ablation of the tumor in two human patients was also reported by the same group following intravesicle (into the bladder) administration of the DTA-H19 vector (which also showed high killing potential in ovarian cancer cells, see above) complexed with the transfection enhancer reagent Jet-PEI. No apparent toxicity toward the host was observed [406]. Phase I/II clinical studies in 18 patients with H19 over expressing superficial bladder cancer showed 22\% complete response and 44\% complete marker tumor ablation or a $50 \%$ reduction of the marker lesion after six treatments in which the DTA-H19 (BC-819) vector was administrated intravesically as a complex with polyethyleneimine. No dose limiting toxicity was observed and the most frequent adverse events were mild to moderate bladder discomfort, dysuria, micturition urgency, urinary tract infection, diarrhea, hypertension and asthenia [344].

\subsection{Targeting Viral Infected Cells}

HIV-1, the main cause of acquired immune deficiency syndrome (AIDS), has been the most studied infectious agent in the last 30 years. The HIV retroviral genome carries six regulatory genes, including 
Tat, Rev, Vpr, Vif, Vpu, and Nef. Of these genes, Tat encodes a protein that plays key roles in controlling productive and processive viral gene transcription. The Tat protein binds to the specific sequences of TAR (Transactivation Response Element) located in the 5' LTR, one of two terminal repeated segments of the viral genome, and exerts its effect by increasing the rate of transcription of the nascent HIV RNA. The viral Rev protein was found to be required for expression of the viral late gene products. By binding to a secondary RNA structure, the Rev-responsive element (RRE), the Rev protein tethers partially spliced and unspliced viral RNAs encoding the late viral proteins to the cellular CRM-1-mediated nuclear-export pathway, leading to enhanced cytoplasmic levels of these RNAs and increased expression of the encoded proteins [407-412]. Applying the knowledge about these viral molecular mechanisms for regulated gene expression, Harrison et al. have demonstrated the use of a combination of Tat and Rev cis-acting responsive sequences for achieving enhanced expression of transgenes in cells expressing both regulatory trans-acting Tat and Rev proteins; while maintaining low basal expression in naive cells [413]. Substantially impaired HIV production, following HIV proviral DNA transfection of HeLa cells containing integrated HIV-regulated (Tat-Rev responsive) DT-A gene, was shown in a subsequent study [414]. A T-Cell line (H9) that was transduced with a recombinant retroviral vector encoding HIV regulated wild-type or attenuated DT-A gene also showed substantially long-term impaired ability to produce HIV virions upon transfection with proviral DNA or infection with laboratory or clinical HIV strains $[348,415]$. Using the same construct, significant protection against HIV infection (dependent both on the stock of HIV-1 used and on the dose) was also observed in the U937 cell line which exhibits many of the characteristics of tissue monocytes that serve as an important reservoir for the virus in vivo [349,416]. It was later reported that co-transfection of the HIV regulated DT-A construct (HIV-DT-A) with an HIV proviral DNA using cationic liposome-mediated gene delivery ("lipofection") could prevent virus production in HeLa cells. However, although HIV-regulated genes were found to be expressed when transfected into chronically HIV infected cells, transfection with HIV-DT-A did not significantly reduce virus production in an already chronically or de novo HIV-infected cell population, probably due to the low percentage ( $\sim 5 \%)$ of "lipofected" cells [350].

\section{Protease Activated Toxins}

\subsection{Extracellular Protease Activated Toxins}

Cytotoxic activity of PE, DT and other bacterial toxins (like the anthrax toxin that will be described in the following section) depends on a proteolytic cleavage taking place in an early step of the intoxication process $[122,123,157,158,417-420]$. Since different disease-related cells are sometimes associated with a distinguished extracellular proteolytic activity, as will be discussed shortly, it is conceivable that replacing the natural cleavage site of a toxin with that of a disease-related protease may confer the new molecule with the ability to specifically eradicate disease-related cells (Figure 1). Several studies in which such molecules have been developed and preclinically evaluated, classified by their targets, are described in the following chapter. Information about the reviewed and other extracellular activated toxins is summarized in Table 3. 
Table 3. Preclinically Evaluated/under Evaluation Protease Activated Toxins.

\begin{tabular}{|c|c|c|c|c|c|c|c|}
\hline $\begin{array}{l}\text { Construct } \\
\text { Name }\end{array}$ & \begin{tabular}{|l} 
Activating \\
Protease
\end{tabular} & $\begin{array}{l}\text { Protease } \\
\text { Localization }\end{array}$ & Components & $\begin{array}{l}\text { Toxin } \\
\text { Source }\end{array}$ & $\begin{array}{l}\text { Activation } \\
\text { Mode }\end{array}$ & Target & References \\
\hline $\begin{array}{l}\text { PA-L1/L2 + } \\
\text { FP59 }\end{array}$ & $\begin{array}{l}\text { MMPs } \\
\text { (mainly } \\
\text { MMP2 and } \\
\text { MMP9) }\end{array}$ & Extracellular & $\begin{array}{l}\text { PA (modified) } \\
+ \text { FP59 }\end{array}$ & $\begin{array}{l}\text { Anthrax + } \\
\text { PE }\end{array}$ & $\begin{array}{l}\text { Binding and } \\
\text { translocation of } \\
\text { the toxic moiety }\end{array}$ & $\begin{array}{l}\text { MMPs } \\
\text { expressing } \\
\text { tumor cells }\end{array}$ & [421] \\
\hline PA-L1 + LF & $\begin{array}{l}\text { MMPs } \\
\text { (mainly } \\
\text { MMP2 and } \\
\text { MMP9) }\end{array}$ & Extracellular & $\begin{array}{l}\text { PA (modified) } \\
+\mathrm{LF}\end{array}$ & Anthrax & $\begin{array}{l}\text { Binding and } \\
\text { translocation of } \\
\text { the toxic moiety }\end{array}$ & $\begin{array}{l}\text { Tumor } \\
\text { vasculature; } \\
\text { MMPs } \\
\text { expressing } \\
\text { tumor cells } \\
\text { with V600E B- } \\
\text { Raf mutation }\end{array}$ & [422-424] \\
\hline $\begin{array}{l}\text { PrAg-U2 + } \\
\text { FP59 }\end{array}$ & uPA & Extracellular & $\begin{array}{l}\text { PA (modified) } \\
+ \text { FP59 }\end{array}$ & $\begin{array}{l}\text { Anthrax + } \\
\text { PE }\end{array}$ & $\begin{array}{l}\text { Binding and } \\
\text { translocation of } \\
\text { the toxic moiety }\end{array}$ & $\begin{array}{l}\text { Tumor cells } \\
\text { with receptor- } \\
\text { associated uPA } \\
\text { activity }\end{array}$ & [425-429] \\
\hline $\begin{array}{l}\text { PrAg-L1-I210A } \\
+ \text { PrAg-U2 } \\
\text { R200A + FP59 }\end{array}$ & $\begin{array}{l}\text { MMPs } \\
+ \text { uPA } \\
\text { (both } \\
\text { required) }\end{array}$ & Extracellular & $\begin{array}{l}\text { PA (modified) } \\
+ \text { FP59 }\end{array}$ & $\begin{array}{l}\text { Anthrax + } \\
\text { PE }\end{array}$ & $\begin{array}{l}\text { Binding and } \\
\text { translocation of } \\
\text { the toxic moiety }\end{array}$ & $\begin{array}{l}\text { MMPs } \\
\text { expressing } \\
\text { tumor cells } \\
\text { with receptor- } \\
\text { associated uPA } \\
\text { activity }\end{array}$ & [430] \\
\hline UFT3 & PSA & $\begin{array}{l}\text { Extracellular } \\
\text { and } \\
\text { intracellular }\end{array}$ & $\begin{array}{l}\text { Ubiquitin } \\
\text { (mutant), } \\
\text { saporin }\end{array}$ & Saporin & $\begin{array}{l}\text { Toxin } \\
\text { stabilization }\end{array}$ & $\begin{array}{l}\text { Prostate cancer } \\
\text { cells }\end{array}$ & [431] \\
\hline DTU2GMCSF & uPA & Extracellular & $\begin{array}{l}\mathrm{DT}_{388} \\
\text { (modified), } \\
\text { GM-CSF }\end{array}$ & DT & $\begin{array}{l}\text { Translocation of } \\
\text { the toxic moiety }\end{array}$ & $\begin{array}{l}\text { AML cells } \\
\text { (the toxin is } \\
\text { targeted also by } \\
\text { fusion to } \\
\text { GM-CSF) }\end{array}$ & [432] \\
\hline $\begin{array}{l}\text { FLD/MM, } \\
\text { FLD/YV }\end{array}$ & $\begin{array}{l}\text { HIV-1 } \\
\text { protease }\end{array}$ & Intracellular & $\mathrm{PA}+\mathrm{LF}_{\mathrm{N}}-\mathrm{DTA}$ & $\begin{array}{l}\text { Anthrax + } \\
\text { DT }\end{array}$ & $\begin{array}{l}\text { Toxin } \\
\text { stabilization }\end{array}$ & $\begin{array}{l}\text { HIV-1 infected } \\
\text { cells }\end{array}$ & [433] \\
\hline $\begin{array}{l}\text { TAT-Pro-HIV- } \\
\text { p2/NC, TAT- } \\
\text { Pro-HIV- } \\
\text { MA/CA }\end{array}$ & $\begin{array}{l}\text { HIV-1 } \\
\text { protease }\end{array}$ & Intracellular & $\begin{array}{l}\text { HIV-1 TAT } \\
\text { transduction } \\
\text { peptide, Maize } \\
\text { RIP (modified) }\end{array}$ & $\begin{array}{l}\text { Maize } \\
\text { RIP }\end{array}$ & $\begin{array}{l}\text { Enhancement in } \\
\text { the enzymatic } \\
\text { activity of the } \\
\text { toxic moiety }\end{array}$ & $\begin{array}{l}\text { HIV-1 infected } \\
\text { cells }\end{array}$ & [434] \\
\hline
\end{tabular}

Abbreviations: PE: pseudomonas exotoxin A; DT: diphtheria toxin; DTA/DT-A: the catalytic A fragment of diphtheria toxin; $\mathrm{DT}_{388}$ : truncated form of DT; MMPs: matrix metalloproteinases; RIP: ribosome inactivating protein; PA/PrAg: anthrax protective antigen; FP59: anthrax toxin lethal factor residues 1-254 fused to the ADP-ribosylation domain of PE; PA: anthrax toxin protective antigen; LF: anthrax toxin lethal factor; uPA: urokinase plasminogen activator; NSCLC: non-small cell lung cancer; PSA: prostate-specific antigen; HIV: human immunodeficiency virus; AML: acute myeloid leukemia; GM-CSF: granulocyte macrophage colony-stimulating factor, $\mathrm{LF}_{\mathrm{N}}$ : amino acids 1-255 of anthrax toxin lethal factor. 


\subsubsection{Targeting Matrix Metalloproteinases (MMPs) Overexpressing Tumor Cells}

Matrix metalloproteases (MMPs) are a multigene family of zinc-dependent endopeptidases, which are secreted as latent pro-enzymes and have the capacity to degrade components of the extracellular matrix (ECM) following activating cleavage. In addition, MMPs have the ability to process molecules such as growth factors, receptors, adhesion molecules, other proteinases and proteinase inhibitors. MMPs are basically divided into distinct subclasses according to their substrate specificity and cellular localization: the secreted soluble collagenases, gelatinases, stromelysins and matrilysins; and the membrane-type MMPs which are integral plasma membrane proteins capable of activating MMPs. For certain family members, including some of the membrane-associated MMPs, activating cleavage can be achieved intracellularly by the protease furin. For other MMPs, however, activation is executed by extracellular proteases such as plasmin or other MMPs. While restricted to only a small number of normal cells, several MMPs are overexpressed by different kinds of solid tumors and have been implicated in the ECM degradation associated with tumor growth, angiogenesis and invasiveness [435-439].

Anthrax toxin (AnTx) is a major virulence factor secreted by the gram-positive, spore-forming bacterium Bacillus anthrachis. The toxin, which damages cells and impairs host defenses, belongs to a family of toxins called "binary toxins" which are characterized by consisting of minimally two discrete nontoxic proteins that must be combined to elicit toxicity. AnTx consist of three non-toxic plasmid-encoded multidomain proteins: protective antigen (PA/PrAg; $83 \mathrm{kDa}$ ), lethal factor (LF; $90 \mathrm{kDa}$ ) and edema factor (EF; $89 \mathrm{kDa}$ ) (for review, see [440-442]). Intoxication begins with the binding of PA to either of its two known cellular receptors ATR/TEM8 [443] and CMG2 [444]. PA then undergoes an activating cleavage by a member of the furin family of cellular proteases $[418,420]$, into an N terminal PA63 (63 kDa) and C terminal PA20 (20 kDa) fragments. Following cleavage, receptor-bound PA63 self associate to form a ring-shaped homoheptamer [445], called the prepore, which may then form complexes with up to three molecules of LF and/or EF (each bound LF/EF molecule "occupies" two neighboring PA subunits). The resulting complexes, which are known as lethal toxin (LeTx) and edema toxin (EdTx), respectively, are then internalized via clathrin-dependent receptor-mediated endocytosis [446,447] and delivered to early endosomes where the complex is sorted to the vesicular regions and preferentially incorporated into intraluminal vesicles [448]. Subsequently, the prepore undergoes an acidic $\mathrm{pH}$-dependent conformational change to form a cationselective, ion-conducting channel [449-451]. This channel/pore is thought to participate in the unfolding of LF and EF, and functions in their translocation into the lumen of the intraluminal vesicles or into the cytoplasm, probably with the aid of cytosolic components [452-456]. Following transportation to late endosomes, back fusion of intraluminal vesicles with the limiting membrane delivers the toxic factors, which were "trapped" inside the vesicles lumen, to the cytoplasm [448] (for review about the cellular routing of the anthrax toxin, see [442,457]). Once in the cytoplasm, LF functions as a zinc metalloproteinase that specifically cleaves the N-termini of MKK/MEK proteins (kinases of mitogen-activated protein kinases), blocking their signaling activity [458-466]. EF is a $\mathrm{Ca}^{2+} /$ calmodulin activated adenylate cyclase (AC) that acts by elevating the intracellular level of cyclic AMP (cAMP), upsetting water homeostasis, destroying the delicate balance of intracellular signaling and impairing neutrophil functions [440,467-472] (Figure 6). 
Figure 6. Cellular trafficking of anthrax toxin. 1. The toxins are secreted as 3 polypeptides: protective antigen $(\mathrm{PA} ; 83 \mathrm{kDa})$, lethal factor $(\mathrm{LF} ; 90 \mathrm{kDa})$ and edema factor $(\mathrm{EF} ; 89 \mathrm{kDa})$ (see 3D structure (PDB Entry: PA- 1acc; LF-1j7n; EF- 1y0v). In the left panel, the colors of the different proteins correspond to those in the scheme; 2. PA binds to cellular receptor (ATR/TEM8; CMG2); 3. Cell-surface furin protease cleaves PA into an N terminal PA63 $(63 \mathrm{kDa})$ and $\mathrm{C}$ terminal PA20 $(20 \mathrm{kDa})$ fragments; 4. Receptor bound PA63 self associates into a homoheptamer ("prepore") that can bind up to 3 molecules of LF and/or EF; 5. The complex internalized via clathrin-dependent receptor mediated endocytosis; 6. In the early endosomes (EE), the complex is sorted to the vesicular region and preferentially incorporated into intraluminal vesicles. The acidic environment of the endosome induces a conformational change in the prepore that turns into a channel/pore and functions in the translocation of LF and/or EF to the lumen of intraluminal vesicles or to the cytoplasm; 7. Following transportation to late endosome (LE), back fusion of intraluminal vesicles with the limiting membrane delivers the "trapped" toxic factors to the cytoplasm; 8 . In the cytoplasm, LF functions as a zinc metalloproteinase that cleaves the $\mathrm{N}$ termini of $\mathrm{MKK} / \mathrm{MEK}$ proteins, blocking their signaling activity. EF acts as a $\mathrm{Ca}^{2+} /$ calmodulin activated adenylate cyclase that dramatically elevates cytoplasmic cAMP level and consequently disrupts normal cellular activities.
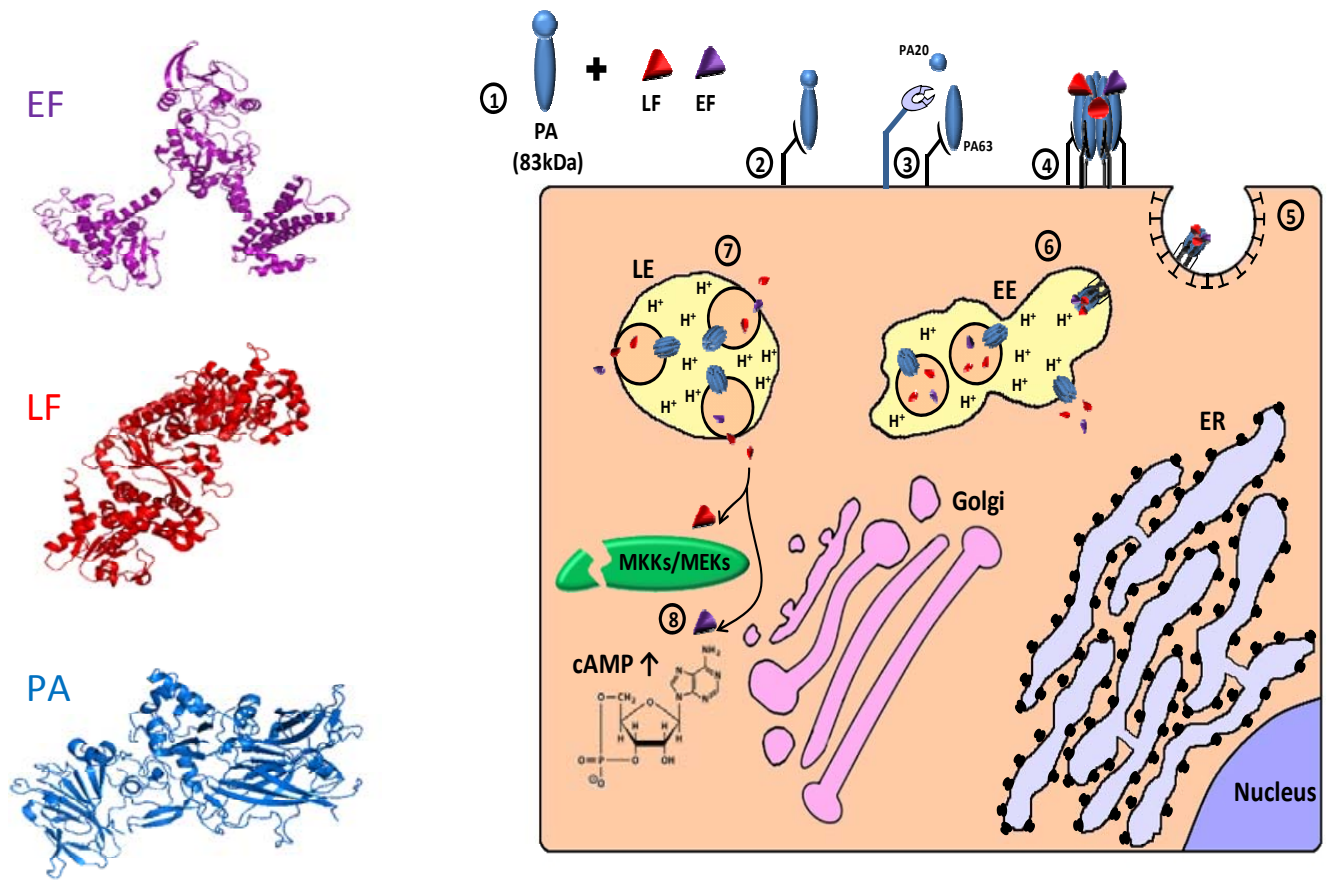

Liu et al [421] were the first to introduce and apply a new concept in which replacing the natural furin cleavage site in anthrax PA protein (such cleavage must occur on the cell surface in order to achieve binding and internalization of a catalytic LF and EF) with a sequence recognized by a tumor-associated protease may confer the recombinant molecule with the ability of targeting the protease overexpressing cells. To this end, in two mutated PA proteins, PA-L1(named also PrAg-L1) and PA-L2, the natural furin recognition site was replaced by sequences susceptible to cleavage by MMP-2 (gelatinase A) and MMP-9 (gelatinase B) that are reported to be related to invasion and 
metastasis in various human cancers [473-476]. The toxic catalytic polypeptide that has been used in this study was a fusion between the ADP-ribosylation domain of Pseudomonas exotoxin A and amino acids 1-254 of LF $\left(\mathrm{LF}_{\mathrm{N}}\right)$, which contains the PA binding domain that proved sufficient to achieve translocation of a fused "passenger" polypeptide to the cytosol of cells in a PA-dependent process [477-479]. By combining the re-engineered PA with the fusion toxic polypeptide (which was denoted FP59), the researchers have demonstrated selective killing of MMP-overexpressing human tumor cell lines while sparing nontumorigenic normal cells. Protection against challenge from PA-L1/L2 plus FP59 by MMP inhibitors further demonstrated that cell killing is highly dependent on the MMPs activity expressed by the tumor cells. Furthermore, specific eradication of MMP overexpressing tumor cells in a co-culture model indicated that PA activation occurred on the tumor cell surface and not in the culture supernatant. Activation of MMPs on the cell membrane by plasmin and/or membrane-anchored MMP, together with binding to cell surface receptors, were proposed as factors that may contribute to the retention of soluble active MMPs on the surface of tumor cells [421].

In contrast to the enzymatically active polypeptide of PE, DT and RIPs, which strongly inhibit protein synthesis causing the death of the intoxicated cell (see above), inactivation of mitogenactivated protein kinase kinases by the action of anthrax lethal factor (LF) was found to selectively kill cells in which an activated MAPK pathway is required for their survival. This is similar to observed for cells bearing the V600E mutation in B-Raf, a serine/threonine kinase immediately upstream of MEK1/2 in the of the ERK MAPK cascade. The mutation, which was demonstrated mainly in melanoma but also in other human malignancies, "locks" the molecule in a constitutively active state, making the cell dependent on the constitutive activation of the ERK pathway for survival [480-483]. However, although specific toxicity toward B-Raf mutant melanoma cells has been observed both in vitro and in xenograft melanoma tumors in mice [481-484], development of LeTx variants with lower in vivo toxicity and high tumor specificity would be required for use in human cancer patients [485].

For the purpose of using LF as a targeted toxic polypeptide with superior specificity, a modified LeTx (PA-L1/LF) composed of LF and MMP activated PA protein was tested in mice xenograft models of human tumors. As expected, the PA-L1/LF showed lower toxicity to mice than wild-type toxin and has a potent anti-tumor activity. Surprisingly, anti-tumor activity was observed not only against human melanomas with B-Raf V600E mutation (due to direct toxicity against these cells), but also against other human tumor types including colon and lung carcinomas, and mouse tumors, regardless of their B-Raf status. Tumor histology and in vivo angiogenesis assays suggested that these effects can be attributed to indirect targeting of tumor vasculature and angiogenic processes (expression of MMPs has been shown to be upregulated in angiogenic lesions [486-489]), in which mitogen-activated protein kinase (MAPK) signaling pathways play a central role $[422,490]$. Later in vitro studies on endothelial proliferation, invasion, and tube formation showed that activated LeTx acts by impairing microvascular endothelial cell invasion and migration in the absence of endothelial cell death [423]. Another intriguing observation was that the PA-L1/LF administration showed higher anti-tumor efficacy than does the wild-type toxin, probably because of greater bioavailability and longer half-life of PA-L1(relative to PA) in circulation [422].

Treatment with PA-L1/LF also delayed tumor growth and improved long-term survival in mice with orthotopically implanted anaplastic thyroid carcinoma (ATC) xenografts. The antitumorogenic effect was comparable with that achieved by the multikinase inhibitor, sorafenib, which is currently 
under evaluation for clinical use in patients with papillary thyroid carcinoma (PTC). As was already found in previous studies [422,423], the therapeutic effect of PA-L1/LF was mediated by the potent antiangiogenic activity of the drug, which did not cause any significant systemic toxicity [424].

\subsubsection{Targeting Malignant Cells Overexpressing the Urokinase Plasminogen Activator System}

Plasminogen is an inactive precursor of plasmin, a serine protease present in plasma and extracellular fluid and is active in the process of fibrinolysis and degradation of extracellular matrix (ECM) components [491]. One of the naturally occurring plasminogen activators is the urokinase-type plasminogen activator (uPA), a serine protease secreted as an inactive pro-enzyme (pro-uPA) that efficiently converted by plasmin or kallikrein into uPA, which in turn cleaves plasminogen to generate the active plasmin in a positive feed-back mechanism. The catalytic efficiency of these reactions is further increased upon binding of pro-uPA/uPA and plasminogen/plasmin to membranal receptors, resulting in reciprocal zymogen activation on the cell surface. The initial proteolytic event leading to the initiation of plasmin generation on the cell surface is still under study [492-498]. While quite restricted in normal tissues, expression of pro-uPA and its receptor, uPAR, was found to be elevated in a significant number of solid tumors. Moreover, the presence of this proteolytic system which confers the tumor mass with the ability to degrade ECM proteins is associated with increased tumor tissue invasiveness and metastatic potential [499,500].

To target tumor cells that overexpress the urokinase plasminogen activator system, the furin cleavage site in anthrax PA protein was replaced by sequences that are specifically cleaved by uPA. The modified PA was then combined with FP59, a fusion between the ADP-ribosylation domain of Pseudomonas exotoxin A and amino acids 1-254 of LF (see above). In the presence of pro-uPA and plasminogen, the recombinant complex (PrAg-U2 + FP59) was demonstrated to be activated selectively on the surface of uPAR-expressing tumor cells from a broad range of human cancers of different origins, and ultimately resulted in specific tumor cell eradication [425,427]. Subsequent in vivo studies have demonstrated efficient suppression of different murine tumors growth and eradication of established tumors with limited toxicity to normal tissue upon local and systemic administration of the complex [426,428]. 100\% tumor regression and 30\% complete histologic remission after systemic administration of tolerated doses of PrAg-U2+FP59 were documented in an in vivo athymic nude mouse model of human non-small cell lung cancer (NSCLC) [429].

The requirement of two activating proteolytic events by two different tumor-associated proteases may confer the toxic agent with superior cell-type specificity and further attenuate its toxicity to normal tissues. In an elegant work performed by Liu et al [430], an intermolecular complementation approach was used for the targeting of tumor cells having both MMP and uPA activities which are overproduced by tumor tissues and are implicated in cancer cell growth and metastasis [435-439,499,500]. To this end, the authors exploited the findings that the anthrax LF binding site spans two adjacent monomers of cleaved PA in the oligomeric prepore. Each monomer contains three subsites which play a role in the binding of LF. However, the functional LF binding site is composed of a combination of subsites contributed by two adjacent subunits: subsite I and III form one monomer and subsite II from the neighboring subunit [501,502]. By mutating LF binding subsite III on an MMP activated PA (PrAg-L1) and subsite II on uPA activated PA (PrAg-U2), assembly of PA heptamer in 
which every LF binding site contains the inactivating subsite III or subsite II mutation will occur following activating cleavage by either MMP or UPA, respectively. However, adding a mixture of these modified PA proteins to cells that have both MMP and UPA activities would generate two subunits that can randomly assemble into a heptamer in which up to three functional LF binding sites may be generated by intermolecular complementation between the two types of mutated subunits. In order to test the hypothesis that requirement of two tumor-associated activating proteolytic events may attenuate toxicity to normal tissues, an in vivo toxicity assay in mice was performed by intraperitoneal administration of a mixture containing subsite III mutated PrAg-L1 (PrAg-L1-I210A), subsite II mutated PrAg-U2 (PrAg-U2-R200A) and the toxic FP59 chimeric polypeptide. Indeed, results showed decreased toxicity in comparison to administration of a mixture of PrAg-L1, PrAg-U2 and FP59 (where either MMP or uPA proteolytic activity was sufficient to generate a functional LF binding prepore).

When the combination of PrAg-U2-R200A and PrAg-L1-I210A (with FP59) was evaluated in treatment of three mouse tumor types (B16-BL6 melanoma, T241 fibrosarcoma, and LL3 Lewis lung carcinoma), a strong anti-tumor activity was observed. In contrast, the tumors showed little or no response to treatment with the individual proteins, demonstrating the necessity of intermolecular complementation between these engineered PA/PrAg proteins for the execution of a potent tumoricidal activity. In an anti-tumor efficacy comparing assay, the combination of PrAg-U2-R200A and PrAg-L1-I210A was at least as effective as an equivalent dose of PrAg-U2. However, given that the maximum tolerated dose of PrAg-U2-R200A/PrAg-L1-I210A is higher than that of PrAg-U2, the complementing mixture achieves higher tumor specificity [430].

\subsection{Intracellular Protease Activated Toxins}

The life cycle of many viruses depends upon viral proteases for the cleavage of high molecular weight precursor viral proteins in order to yield functional products or by catalyzing the processing of the structural and non-structural proteins that are necessary for assembly and morphogenesis of viral particles. A partial list of human disease-associated viruses encoding protease(s) in their genomes include flaviviruses such as: hepatitis $\mathrm{C}$ virus (HCV), West Nile virus (WNV), dengue fever virus (DFV) and yellow fever virus (YFV); retroviruses such as HIV-1; picornaviruses such as coxsackievirus, poliovirus and hepatitis A virus; nidoviruses such as coronaviruses ( $\mathrm{CoV})$, including the severe acute respiratory syndrome (SARS) causative SARS-CoV; and herpesviruses such as varicella-zoster virus (VZV) and Epstein-Bar virus (EBV) [503-505]. As expression of the viral protease distinguishes an infected cell from surrounding healthy tissue, limiting virus production and spread by a viral-protease activated toxin that specifically eradicates infected cells may comprise an attractive antiviral approach (Figure 1). Selected preclinical studies in the field are described in the following chapter. Information about the reviewed intracellular activated toxins is also summarized in Table 3.

\subsubsection{Targeting HIV Infected Cells}

The half-lives of proteins in a living cell range from a few seconds to many days. Features of proteins that confer metabolic instability are called degradation signals, or degrons. The N-end rule 
degron (N-degron), which was the first to be discovered, relates the in vivo half-life of a protein to the identity of its amino-terminal residue. In eukaryotes, the $\mathrm{N}$-degron comprises at least two determinants: a destabilizing N-terminal residue and internal lysine/s that function as acceptor site/s for the formation of a multi-ubiquitin chain that "marks" the ubiquitin-protein conjugates as a substrate for proteosomal degradation. Destabilizing residues in mammalian cells can be hierarchically divided into three classes: Primary (type 1 (Arg, Lys or His) or type 2 (Ile, Leu, Phe, Tyr or Trp)), secondary (Asp, Glu or oxidized Cys) and tertiary (Asn, Gln or Cys) (reviewed in [506-511]).

In a comprehensive study by Falnes et al [512], the in vivo stability and cytotoxicity of diphtheria toxin-based polypeptides, artificially modified to initiate with short sequences derived from the FLAG peptide epitope differing only in their N-terminal amino acids, were assessed. According to their findings, when the first $\mathrm{N}$ terminal amino acid of the modified toxins were Phe, Tyr, Trp, Asp, Asn, Glu, Gln, Lys, Arg or His, the proteins were highly unstable, with half-lives in the range 0.2-1.6 hours, while the toxins initiated with either of the remaining amino acids were considerably more stable, with half-lives ranging from 3 to $>12$ hours.

An in vitro study in reticulocyte lysates indicated that the ten $\mathrm{N}$ terminal amino acids that confer the toxin with short in vitro half life were also the most destabilizing ones in vivo. Moreover, cytotoxicity assays in Vero cells showed a clear correlation between the in vivo stability and the cytotoxicity of the proteins, although the difference in cytotoxicity between the wild-type DT-A fragment and the least stable mutant was only $\sim 20$-fold in compared to $\sim 100$-fold difference in intracellular half-life [512].

Alexander Varshavsky suggested previously the construction of a new kind of toxins where a signal that inactivates the toxin, e.g. a degradation signal, can be cleaved off by a viral protease, resulting in selective intoxication of virally infected cells. He denoted such toxins "sitoxins" (signal-regulated, cleavage mediated toxins) [506]. For the construction of such viral-protease activated sitoxins, Falnes et al designed fusion proteins composed of a FLAG peptide containing an N-terminal phenylalanine (a destabilizing amino acid according to the N-end rule), followed by an HIV-1 protease (HIV-1 PR) cleavage sites that is positioned upstream to a chimeric sequence between DT-A and the first PA-binding 255 amino acids of the anthrax LF, the LF $_{N}$ fragment, which was also shown to be destabilized by the addition of a degradation signal for N-end-rule-mediated degradation [513]. The rationale behind this construct was that following anthrax PA-mediated translocation into the cytoplasm of uninfected cells, the modified toxin would be rapidly degraded by virtue of its destabilizing $\mathrm{N}$-degron, resulting in attenuated cytotoxic activity against these uninfected cells. In contrast, cleavage of the construct by the HIV-1 protease whose activity has been documented in the cytosol of acutely infected cells [514-518] would result in the removal of the destabilizing $\mathrm{N}$ degron from the chimeric toxin, exposing a new $\mathrm{N}$ terminal amino acid. As HIV-PR cleavage in each of its two recognition sequences that were chosen (TATIM*MQRG or VSQNY*VIVQ) generates a stabilizing $\mathrm{N}$ terminal residue (methionine or valine, respectively) according to the $\mathrm{N}$-end rule, a longlife toxin with a potent cytotoxic activity is generated in HIV infected cells which leads to their destruction. Indeed, in vitro and in vivo simulating experiments showed that when the constructs were pre-digested with HIV-PR, both stability and cytotoxicity of the chimeric toxins was considerably augmented, proving that the concept of stabilizing a protein through specific proteolytic removal of a degradation signal works in practice. However, no selective eradication of HIV infected cells was 
observed following treatment with non pre-treated constructs, probably because of low cytosolic HIV-1 PR activity (no proteolytic processing of the constructs were detected in HIV-infected cells) [433].

In another study, which was performed by Law et al [434], HIV protease-activated toxins were designed on the basis of the type III maize ribosome-inactivating protein, which in its native form is synthesized as inactive precursor (pro-RIP) and is activated by proteolytic removal of a 25 amino-acid inhibitory internal peptide in-planta [218,219]. In this work, the first and the last 10 residues of the internal inactivation region were replaced with two HIV-PR recognition sequences, and an 11 amino-acids transduction peptide derived from the HIV-1 Tat protein was fused to the N-termini of the modified RIPs for promoting cell entry [519]. These modifications resulted in the generation of re-engineered pro-RIPs which underwent an efficient cleavage in vitro by recombinant HIV-PR or in vivo (in HIV infected cells) by the viral encoded protease. Upon treatment of infected cells, the $N$-glycosidase and anti-viral activities of the modified cleavable RIPs were found to be higher than those of an uncleavable-nonactivated pro-RIP and resembled those of an activated mutant in which the inhibitory region was genetically removed. The cytotoxic activity of the cleavable RIPs against infected cells was not reported, but cytotoxicity toward uninfected cells was found to be lower than that of the activated mutant. Thus, the fact that the cleavable toxins behave more like a constitutively active form toward infected cells and in a similar way to a non-activated form toward uninfected cells, may suggest that they are specifically activated by the HIV protease and demonstrates the possibility of using this cleavable internal inactivation region as a switch to activate the toxin inside infected cells [434].

\section{Concluding Remarks}

Treating cancer and chronic viral infections are among the most challenging goals in modern medicine. The recent integration of modified plant and bacterial toxins based therapies (and particularly immunotoxins with anti-tumor activity) into clinical research and application adds new weapons to the arsenal against these refractory diseases. Cumulative knowledge about toxins' structure and mechanism of action, as well as recent progress and breakthroughs in the fields of cell biology, immunology, virology, molecular biology and nanotechnology, enabled the development of different targeting strategies that are crucial for converting a lethal toxin into a therapeutic agent (see Figure 1). However, clinical application of engineered toxins still faces many challenges. Two major problems associated with systemic administration of immunotoxins are: 1. lack of specificity resulting from the presence of the target antigen/receptor also being present on healthy tissue ("target dependent toxicity"); 2. Undesired intoxication of healthy tissue due to the immunotoxin binding to cell surface components rather than specifically to its target antigen/receptor ("target independent toxicity"). Whereas the first problem directly relates to the target and its expression/body-distribution profile; the second relates to the nature of the therapeutic agent itself.

The most common toxicities in patients treated with immunotoxins are vascular leak syndrome (VLS) and hepatotoxicity, caused by non-specific binding of the toxic or the targeting moiety of the immunotoxin to endothelial and hepatic cells, respectively (for review, see [11,520,521]). Regarding this issue, Baluna et al have found that sequences of three amino acids in ricin toxin (and in other proteins associated with vascular leak syndrome) might cause endothelial damage by a mechanism 
involving disruption of integrins, independently of the "classical" cell killing mediated by the toxin's enzymatic activity [522]. By screening a panel of recombinant ricin A chains with mutations in this sequence or in amino acids flanking it in the three-dimensional structure, a mutant form of RTA showing diminished VLS in mice was isolated [523,524].

While pharmacokinetics issues and non-specific toxicity are common problems associated with the development of many drugs and particularly with the development of chemotherapeutic agents; immunogenicity is a major challenge distinguishing immunotoxins from small molecule-based therapy. Immunotoxins generally contain at least one non-human component which might be the bacterial/plant derived toxic moiety and/or an antibody from animal origin. Consequently, anti-drug antibody formation may be induced in immune-competent patients, resulting in a compromised treatment efficiency caused by the decrease in the level of circulating functional agent. The issue of human-anti mouse antibody (HAMA) formation against immunotoxins, in which the targeting moiety is a monoclonal antibody produced by hybridoma cells, has been overcome to a great extent by the development of chimeric, humanized and fully human antibodies using recombinant DNA technology (reviewed by [525,526]). Attempts to use polyethylene glycol ("PEGylation") [527-529] and immunosuppressive agents [105,107,530-532] have led to different success rates in reducing the immunogenic response against non-human components of immunotoxins. Deletion of B-cell and T-cell epitopes located on the surface of the toxic moieties is another option for reducing their immunogenicity. Recent studies conducted by Onda et al revealed seven major conformational B-cell epitopes on the PE38 molecule [533]. By mutation of specific large hydrophilic amino acids on the surface of the PE38 component in the immunotoxin BL22 (see above), most of the B cell epitopes were eliminated and a new fully functional immunotoxin which is significantly less immunogenic to mice was created [534]. Taking advantage of this knowledge, Oh et al have created a bispecific cytotoxic polypeptide in which human epidermal growth factor (EGF) and interleukin-4 (IL-4) are linked to the B-cell epitopes-deleted PE38. When administrated to a mouse model of metastatic breast carcinoma, immunogenicity was reduced by about $90 \%$ (in comparison to the non-mutated construct) with no apparent loss of anti-tumor activity [535].

Concerning protease activated toxins and toxin based suicide gene therapy, clinical data is scarce as most developments in this field have not been evaluated clinically. However, it is conceivable that the specificity issues will remain relevant also for these agents as the transcription or proteolytic activity that execute their toxicity are rarely associated exclusively with a diseased cell, but rather, as was previously mentioned, have also a physiological role in healthy tissue. As in the case of immunotoxins, immunogenicity may also be a problem that must be overcome when treating immuno-competent patients with protease activated toxins or toxin based suicide gene therapy, either because of the immunogenicity of the cleavable toxin or the immunogenicity of the viral vecto.

In conclusion, toxin-based therapy is a versatile and dynamic research area with a great application potential, as demonstrated in this review. However, further research is required in order to improve the efficiency and safety of toxin-based agents. Investments in the development of delivery and targeting techniques are definitely required in order to achieve this goal, but nevertheless the basic research on the structure and mechanism of natural toxins should not be abandoned. The deeper our knowledge about this unique family of secreted polypeptides, the easier for us to harness their great potential for our own benefit. 


\section{References}

1. Kostrzewa, R.; Segura-Aguilar, J. Botulinum neurotoxin: Evolution from poison, to research tool—onto medicinal therapeutic and future pharmaceutical panacea. Neurotox. Res. 2007, 12, 275-290.

2. Mahajan, S.T.; Brubaker, L. Botulinum toxin: From life-threatening disease to novel medical therapy. Am. J. Obstet. Gynecol. 2007, 196, 7-15.

3. Erbguth, F.J. From poison to remedy: The chequered history of botulinum toxin. J. Neur. Transm. 2008, 115, 559-565.

4. Truong, D.D.; Stenner, A.; Reichel, G. Current Clinical Applications of Botulinum Toxin. Curr. Pharm. Design 2009, 15, 3671-3680.

5. Winau, F.; Westphal, O; Winau, R. Paul Ehrlich-In search of the magic bullet. Microb. Infect. 2004, 6, 786-789.

6. Bosch, F.; Rosich, L. The contributions of Paul Ehrlich to pharmacology: A tribute on the occasion of the centenary of his Nobel Prize. Pharmacology 2008, 82, 171-179.

7. Strebhardt, K.; Ullrich, A. Paul Ehrlich's magic bullet concept: 100 years of progress. Nat. Rev. Canc. 2008, 8, 473-480.

8. Moolten, F.L.; Cooperband, S.R. Selective destruction of target cells by diphtheria toxin conjugated to antibody directed against antigens on the cells. Science 1970, 169, 68-70.

9. Moolten, F.; Zajdel, S.; Cooperband, S. Immunotherapy of experimental animal tumors with antitumor antibodies conjugated to diphtheria toxin or ricin. Ann. NY Acad. Sci. 1976, 277, 690-699.

10. Pastan, I.; Hassan, R.; FitzGerald, D.J.; Kreitman, R.J. Immunotoxin treatment of cancer. Annu. Rev. Med. 2007, 58, 221-237.

11. Kreitman, R.J. Immunotoxins for targeted cancer therapy. AAPS J. 2006, 8, E532-E551.

12. Brumlik, M.J.; Daniel, B.J.; Waehler, R.; Curiel, D.T.; Giles, F.J.; Curiel, T.J. Trends in immunoconjugate and ligand-receptor based targeting development for cancer therapy. Expert Opin. Drug Deliv. 2008, 5, 87-103.

13. Potala, S.; Sahoo, S.K.; Verma, R.S. Targeted therapy of cancer using diphtheria toxin-derived immunotoxins. Drug Discov. Today 2008, 13, 807-815.

14. Fuchs, H.; Bachran, C. Targeted tumor therapies at a glance. Curr. Drug Targets 2009, 10, 89-93.

15. Kreitman, R.J. Recombinant immunotoxins containing truncated bacterial toxins for the treatment of hematologic malignancies. BioDrugs 2009, 23, 1-13.

16. Fracasso, G.; Stirpe, F.; Colombatti, M. Ribosome-Inactivating Protein-Containing Conjugates for Therapeutic Use. In Toxic Plant Proteins; Lord, J.M., Hartley, M.R., Eds.; Springer: Berlin/Heidelberg, Germany, 2010; Volume 18, pp. 225-263.

17. Bagel, J.; Garland, W.T.; Breneman, D.; Holick, M.; Littlejohn, T.W.; Crosby, D.; Faust, H.; Fivenson, D.; Nichols, J. Administration of DAB389IL-2 to patients with recalcitrant psoriasis: A double-blind, phase II multicenter trial. J. Am. Acad. Dermatol. 1998, 38, 938-944. 
18. Olsen, E.; Duvic, M.; Frankel, A.; Kim, Y.; Martin, A.; Vonderheid, E.; Jegasothy, B.; Wood, G.; Gordon, M.; Heald, P.; Oseroff, A.; Pinter-Brown, L.; Bowen, G.; Kuzel, T.; Fivenson, D.; Foss, F.; Glode, M.; Molina, A.; Knobler, E.; Stewart, S.; Cooper, K.; Stevens, S.; Craig, F.; Reuben, J.; Bacha, P.; Nichols, J. Pivotal phase III trial of two dose levels of denileukin diftitox for the treatment of cutaneous T-cell lymphoma. J. Clin. Oncol. 2001, 19, $376-388$.

19. Frankel, A.E.; Fleming, D.R.; Hall, P.D.; Powell, B.L.; Black, J.H.; Leftwich, C.; Gartenhaus, R. A phase II study of DT fusion protein denileukin diftitox in patients with fludarabine-refractory chronic lymphocytic leukemia. Clin. Canc. Res. 2003, 9, 3555-3561.

20. Dang, N.H.; Hagemeister, F.B.; Pro, B.; McLaughlin, P.; Romaguera, J.E.; Jones, D.; Samuels, B.; Samaniego, F.; Younes, A.; Wang, M.; Goy, A.; Rodriguez, M.A.; Walker, P.L.; Arredondo, Y.; Tong, A.T.; Fayad, L. Phase II study of denileukin diftitox for relapsed/refractory B-Cell non-Hodgkin's lymphoma. J. Clin. Oncol. 2004, 22, 4095-4102.

21. Shaughnessy, P.J.; Bachier, C.; Grimley, M.; Freytes, C.O.; Callander, N.S.; Essell, J.H.; Flomenberg, N.; Selby, G.; Lemaistre, C.F. Denileukin diftitox for the treatment of steroidresistant acute graft-versus-host disease. Biol. Blood Marrow Transplant. 2005, 11, 188-193.

22. Frankel, A.E.; Surendranathan, A.; Black, J.H.; White, A.; Ganjoo, K.; Cripe, L.D. Phase II clinical studies of denileukin diftitox diphtheria toxin fusion protein in patients with previously treated chronic lymphocytic leukemia. Cancer 2006, 106, 2158-2164.

23. Dang, N.H.; Pro, B.; Hagemeister, F.B.; Samaniego, F.; Jones, D.; Samuels, B.I.; Rodriguez, M.A.; Goy, A.; Romaguera, J.E.; McLaughlin, P.; Tong, A.T.; Turturro, F.; Walker, P.L.; Fayad, L. Phase II trial of denileukin diftitox for relapsed/refractory T-cell non-Hodgkin lymphoma. Br. J. Haematol. 2007, 136, 439-447.

24. Gerena-Lewis, M.; Crawford, J.; Bonomi, P.; Maddox, A.M.; Hainsworth, J.; McCune, D.E.; Shukla, R.; Zeigler, H.; Hurtubise, P.; Chowdhury, T.R.; Fletcher, B.; Dyehouse, K.; Ghalie, R.; Jazieh, A.R. A Phase II trial of Denileukin Diftitox in patients with previously treated advanced non-small cell lung cancer. Am. J. Clin. Oncol. 2009, 32, 269-273.

25. Prince, H.M.; Duvic, M.; Martin, A.; Sterry, W.; Assaf, C.; Sun, Y.; Straus, D.; Acosta, M.; Negro-Vilar, A. Phase III placebo-controlled trial of denileukin diftitox for patients with cutaneous T-cell lymphoma. J.Clin. Oncol. 2010, 28, 1870-1877.

26. LeMaistre, C.F.; Meneghetti, C.; Rosenblum, M.; Reuben, J.; Parker, K.; Shaw, J.; Deisseroth, A.; Woodworth, T.; Parkinson, D.R. Phase I trial of an interleukin-2 (IL-2) fusion toxin (DAB486IL-2) in hematologic malignancies expressing the IL-2 receptor. Blood 1992, 79, 2547-2554.

27. Kuzel, T.M.; Rosen, S.T.; Gordon, L.I.; Winter, J.; Samuelson, E.; Kaul, K.; Roenigk, H.H.; Nylen, P.; Woodworth, T. Phase I trial of the diphtheria toxin/interleukin-2 fusion protein DAB486IL-2: Efficacy in mycosis fungoides and other non-Hodgkin's lymphomas. Leuk. Lymphoma 1993, 11, 369-377.

28. LeMaistre, C.F.; Craig, F.E.; Meneghetti, C.; McMullin, B.; Parker, K.; Reuben, J.; Boldt, D.H.; Rosenblum, M.; Woodworth, T. Phase I trial of a 90-minute infusion of the fusion toxin DAB486IL-2 in hematological cancers. Canc. Res. 1993, 53, 3930-3934. 
29. Platanias, L.C.; Ratain, M.J.; O'Brien, S.; Larson, R.A.; Vardiman, J.W.; Shaw, J.P.; Williams, S.F.; Baron, J.M.; Parker, K.; Woodworth, T.G. Phase I trial of a genetically engineered interleukin-2 fusion toxin (DAB486IL-2) as a 6 hour intravenous infusion in patients with hematologic malignancies. Leuk. Lymphoma 1994, 14, 257-262.

30. Tepler, I.; Schwartz, G.; Parker, K.; Charette, J.; Kadin, M.E.; Woodworth, T.G.; Schnipper, L.E. Phase I trial of an interleukin-2 fusion toxin (DAB486IL-2) in hematologic malignancies: Complete response in a patient with Hodgkin's disease refractory to chemotherapy. Cancer 1994, 73, 1276-1285.

31. Moreland, L.W.; Sewell, K.L.; Trentham, D.E.; Bucy, R.P.; Sullivan, W.F.; Schrohenloher, R.E.; Shmerling, R.H.; Parker, K.C.; Swartz, W.G.; Woodworth, T.G.; et al. Interleukin-2 diphtheria fusion protein (DAB486IL-2) in refractory rheumatoid arthritis. A double-blind, placebocontrolled trial with open-label extension. Arthritis Rheum. 1995, 38, 1177-1186.

32. Laske, D.W.; Youle, R.J.; Oldfield, E.H. Tumor regression with regional distribution of the targeted toxin TF-CRM107 in patients with malignant brain tumors. Nat. Med. 1997, 3, $1362-1368$.

33. Weaver, M.; Laske, D.W. Transferrin receptor ligand-targeted toxin conjugate (Tf-CRM107) for therapy of malignant gliomas. J. Neurooncol. 2003, 65, 3-13.

34. Debinski, W. Molecular targeting with recombinant cytotoxins for the treatment of brain tumors. Drug Dev. Res. 2008, 69, 407-414.

35. Frankel, A.E.; Powell, B.L.; Hall, P.D.; Case, L.D.; Kreitman, R.J. Phase I trial of a novel diphtheria toxin/granulocyte macrophage colony-stimulating factor fusion protein (DT388GMCSF) for refractory or relapsed acute myeloid leukemia. Clin. Canc. Res. 2002, 8, 1004-1013.

36. Frankel, A.E.; Zuckero, S.L.; Mankin, A.A.; Grable, M.; Mitchell, K.; Lee, Y.J.; Neville, D.M.; Woo, J.H. Anti-CD3 recombinant diphtheria immunotoxin therapy of cutaneous $\mathrm{T}$ cell lymphoma. Curr. Drug Targets 2009, 10, 104-109.

37. Woo, J.H.; Lee, Y.J.; Neville, D.M.; Frankel, A.E. Pharmacology of anti-CD3 diphtheria immunotoxin in CD3 positive T-cell lymphoma trials. Meth. Mol. Biol. 2010, 651, 157-175.

38. Testa, U.; Riccioni, R.; Biffoni, M.; Diverio, D.; Lo-Coco, F.; Foa, R.; Peschle, C.; Frankel, A.E. Diphtheria toxin fused to variant human interleukin-3 induces cytotoxicity of blasts from patients with acute myeloid leukemia according to the level of interleukin-3 receptor expression. Blood 2005, 106, 2527-2529.

39. Pai, L.; Bookman, M.; Ozols, R.; Young, R.; Smith, J., 2d; Longo, D.; Gould, B.; Frankel, A.; McClay, E.; Howell, S. Clinical evaluation of intraperitoneal Pseudomonas exotoxin immunoconjugate OVB3-PE in patients with ovarian cancer. J. Clin. Oncol. 1991, 9, 2095-2103.

40. Pai-Scherf, L.H.; Villa, J.; Pearson, D.; Watson, T.; Liu, E.; Willingham, M.C.; Pastan, I. Hepatotoxicity in Cancer Patients Receiving erb-38, a Recombinant Immunotoxin That Targets the erbB2 Receptor. Clin. Canc. Res. 1999, 5, 2311-2315.

41. Hassan, R.; Bullock, S.; Premkumar, A.; Kreitman, R.J.; Kindler, H.; Willingham, M.C.; Pastan, I. Phase I study of SS1P, a recombinant anti-mesothelin immunotoxin given as a bolus I.V. infusion to patients with mesothelin-expressing mesothelioma, ovarian, and pancreatic cancers. Clin. Canc. Res. 2007, 13, 5144-5149. 
42. Kreitman, R.J.; Hassan, R.; Fitzgerald, D.J.; Pastan, I. Phase I trial of continuous infusion anti-mesothelin recombinant immunotoxin SS1P. Clin. Canc. Res. 2009, 15, 5274-5279.

43. Pai, L.H.; Wittes, R.; Setser, A.; Willingham, M.C.; Pastan, I. Treatment of advanced solid tumors with immunotoxin LMB-1: An antibody linked to Pseudomonas exotoxin. Nat. Med. 1996, 2, 350-353.

44. Kreitman, R.J.; Wilson, W.H.; Bergeron, K.; Raggio, M.; Stetler-Stevenson, M.; FitzGerald, D.J.; Pastan, I. Efficacy of the Anti-CD22 Recombinant Immunotoxin BL22 in ChemotherapyResistant Hairy-Cell Leukemia. New Engl. J. Med. 2001, 345, 241-247.

45. Kreitman, R.J.; Squires, D.R.; Stetler-Stevenson, M.; Noel, P.; FitzGerald, D.J.P.; Wilson, W.H.; Pastan, I. Phase I Trial of Recombinant Immunotoxin RFB4(dsFv)-PE38 (BL22) in Patients With B-Cell Malignancies. J. Clin. Oncol. 2005, 23, 6719-6729.

46. Kreitman, R.J.; Stetler-Stevenson, M.; Margulies, I.; Noel, P.; FitzGerald, D.J.P.; Wilson, W.H.; Pastan, I. Phase II Trial of Recombinant Immunotoxin RFB4(dsFv)-PE38 (BL22) in Patients With Hairy Cell Leukemia. J. Clin. Oncol. 2009, 27, 2983-2990.

47. Wayne, A.S.; Kreitman, R.J.; Findley, H.W.; Lew, G.; Delbrook, C.; Steinberg, S.M.; StetlerStevenson, M.; FitzGerald, D.J.; Pastan, I. Anti-CD22 Immunotoxin RFB4(dsFv)-PE38 (BL22) for CD22-Positive Hematologic Malignancies of Childhood: Preclinical Studies and Phase I Clinical Trial. Clin. Canc. Res. 2010, 16, 1894-1903.

48. Kreitman, R.J.; Wilson, W.H.; White, J.D.; Stetler-Stevenson, M.; Jaffe, E.S.; Giardina, S.; Waldmann, T.A.; Pastan, I. Phase I Trial of Recombinant Immunotoxin Anti-Tac(Fv)-PE38 (LMB-2) in Patients With Hematologic Malignancies. J. Clin. Oncol. 2000, 18, 1622-1636.

49. Azemar, M.; Djahansouzi, S.; Jäger, E.; Solbach, C.; Schmidt, M.; Maurer, A.B.; Mross, K.; Unger, C.; Minckwitz, G.v.; Dall, P.; Groner, B.; Wels, W.S. Regression of Cutaneous Tumor Lesions in Patients Intratumorally Injected with a Recombinant Single-chain Antibody-toxin Targeted to ErbB2/HER2. Breast Canc. Res. Treat. 2003, 82, 155-164.

50. von Minckwitz, G.; Harder, S.; Hovelmann, S.; Jager, E.; Al-Batran, S.E.; Loibl, S.; Atmaca, A.; Cimpoiasu, C.; Neumann, A.; Abera, A.; Knuth, A.; Kaufmann, M.; Jager, D.; Maurer, A.B.; Wels, W.S. Phase I clinical study of the recombinant antibody toxin scFv(FRP5)-ETA specific for the ErbB2/HER2 receptor in patients with advanced solid malignomas. Breast Canc. Res. 2005, 7, R617-R626.

51. Goldberg, M.R.; Heimbrook, D.C.; Russo, P.; Sarosdy, M.F.; Greenberg, R.E.; Giantonio, B.J.; Linehan, W.M.; Walther, M.; Fisher, H.A.; Messing, E.; et al. Phase I clinical study of the recombinant oncotoxin TP40 in superficial bladder cancer. Clin. Canc. Res. 1995, 1, 57-61.

52. Sampson, J.H.; Akabani, G.; Archer, G.E.; Bigner, D.D.; Berger, M.S.; Friedman, A.H.; Friedman, H.S.; Herndon, J.E., 2nd; Kunwar, S.; Marcus, S.; McLendon, R.E.; Paolino, A.; Penne, K.; Provenzale, J.; Quinn, J.; Reardon, D.A.; Rich, J.; Stenzel, T.; Tourt-Uhlig, S.; Wikstrand, C.; Wong, T.; Williams, R.; Yuan, F.; Zalutsky, M.R.; Pastan, I. Progress report of a Phase I study of the intracerebral microinfusion of a recombinant chimeric protein composed of transforming growth factor (TGF)-alpha and a mutated form of the Pseudomonas exotoxin termed PE-38 (TP-38) for the treatment of malignant brain tumors. J. Neurooncol. 2003, 65, $27-35$. 
53. Sampson, J.H.; Reardon, D.A.; Friedman, A.H.; Friedman, H.S.; Coleman, R.E.; McLendon, R.E.; Pastan, I.; Bigner, D.D. Sustained radiographic and clinical response in patient with bifrontalrecurrent glioblastoma multiforme with intracerebral infusion of therecombinant targeted toxin TP-38: Case study. Neuro. Oncol. 2005, 7, 90-96.

54. Sampson, J.H.; Akabani, G.; Archer, G.E.; Berger, M.S.; Coleman, R.E.; Friedman, A.H.; Friedman, H.S.; Greer, K.; Herndon, J.E., 2nd; Kunwar, S.; McLendon, R.E.; Paolino, A.; Petry, N.A.; Provenzale, J.M.; Reardon, D.A.; Wong, T.Z.; Zalutsky, M.R.; Pastan, I.; Bigner, D.D. Intracerebral infusion of an EGFR-targeted toxin in recurrent malignant brain tumors. Neuro. Oncol. 2008, 10, 320-329.

55. Posey, J.A.; Khazaeli, M.B.; Bookman, M.A.; Nowrouzi, A.; Grizzle, W.E.; Thornton, J.; Carey, D.E.; Lorenz, J.M.; Sing, A.P.; Siegall, C.B.; LoBuglio, A.F.; Saleh, M.N. A Phase I Trial of the Single-Chain Immunotoxin SGN-10 (BR96 sFv-PE40) in Patients with Advanced Solid Tumors. Clin. Canc. Res. 2002, 8, 3092-3099.

56. Weber, F.; Asher, A.; Bucholz, R.; Berger, M.; Prados, M.; Chang, S.; Bruce, J.; Hall, W.; Rainov, N.G.; Westphal, M.; Warnick, R.E.; Rand, R.W.; Floeth, F.; Rommel, F.; Pan, H.; Hingorani, V.N.; Puri, R.K. Safety, tolerability, and tumor response of IL4-Pseudomonas exotoxin (NBI-3001) in patients with recurrent malignant glioma. J. Neurooncol. 2003, 64, $125-137$.

57. Weber, F.W.; Floeth, F.; Asher, A.; Bucholz, R.; Berger, M.; Prados, M.; Chang, S.; Bruce, J.; Hall, W.; Rainov, N.G.; Westphal, M.; Warnick, R.E.; Rand, R.W.; Rommell, F.; Pan, H.; Hingorani, V.N.; Puri, R.K. Local convection enhanced delivery of IL4-Pseudomonas exotoxin (NBI-3001) for treatment of patients with recurrent malignant glioma. Acta Neurochir. Suppl. 2003, 88, 93-103.

58. Garland, L.; Gitlitz, B.; Ebbinghaus, S.; Pan, H.; de Haan, H.; Puri, R.K.; Von Hoff, D.; Figlin, R. Phase I trial of intravenous IL-4 pseudomonas exotoxin protein (NBI-3001) in patients with advanced solid tumors that express the IL-4 receptor. J. Immunother. 2005, 28, 376-381.

59. Kreitman, R.J.; Tallman, M.S.; Coutre, S.E.; Robak, T.; Wilson, W.H.; Stetler-Stevenson, M.; Noel, P.; FitzGerald, D.J.; McDevitt, J.T.; Pastan, I. Phase I trial of recombinant immunotoxin CAT-8015 (HA22) in multiply relapsed hairy cell leukemia. J. Clin. Oncol. 2010, 28, 6523.

60. Mussai, F.; Campana, D.; Bhojwani, D.; Stetler-Stevenson, M.; Steinberg, S.M.; Wayne, A.S.; Pastan, I. Cytotoxicity of the anti-CD22 immunotoxin HA22 (CAT-8015) against paediatric acute lymphoblastic leukaemia. Br. J. Haematol. 2010, 150, 352-358.

61. Kunwar, S. Convection enhanced delivery of IL13-PE38QQR for treatment of recurrent malignant glioma: Presentation of interim findings from ongoing phase 1 studies. Acta Neurochir. Suppl. 2003, 88, 105-111.

62. Parney, I.F.; Kunwar, S.; McDermott, M.; Berger, M.; Prados, M.; Cha, S.; Croteau, D.; Puri, R.K.; Chang, S.M. Neuroradiographic changes following convection-enhanced delivery of the recombinant cytotoxin interleukin 13-PE38QQR for recurrent malignant glioma. J. Neurosurg. 2005, 102, 267-275. 
63. Kunwar, S.; Prados, M.D.; Chang, S.M.; Berger, M.S.; Lang, F.F.; Piepmeier, J.M.; Sampson, J.H.; Ram, Z.; Gutin, P.H.; Gibbons, R.D.; Aldape, K.D.; Croteau, D.J.; Sherman, J.W.; Puri, R.K. Direct Intracerebral Delivery of Cintredekin Besudotox (IL13-PE38QQR) in Recurrent Malignant Glioma: A Report by the Cintredekin Besudotox Intraparenchymal Study Group. J. Clin. Oncol. 2007, 25, 837-844.

64. Kunwar, S.; Chang, S.; Westphal, M.; Vogelbaum, M.; Sampson, J.; Barnett, G.; Shaffrey, M.; Ram, Z.; Piepmeier, J.; Prados, M.; Croteau, D.; Pedain, C.; Leland, P.; Husain, S.R.; Joshi, B.H.; Puri, R.K.; for the PRECISE Study Group Phase III randomized trial of CED of IL13-PE38QQR vs Gliadel wafers for recurrent glioblastoma. Neuro. Oncol. 2010, 12, 871-881.

65. Vitetta, E.S.; Stone, M.; Amlot, P.; Fay, J.; May, R.; Till, M.; Newman, J.; Clark, P.; Collins, R.; Cunningham, D.; Ghetie, V.; Uhr, J.W.; Thorpe, P.E. Phase I Immunotoxin Trial in Patients with B-Cell Lymphoma. Canc. Res. 1991, 51, 4052-4058.

66. Amlot, P.; Stone, M.; Cunningham, D.; Fay, J.; Newman, J.; Collins, R.; May, R.; McCarthy, M.; Richardson, J.; Ghetie, V. A phase I study of an anti-CD22-deglycosylated ricin A chain immunotoxin in the treatment of B-cell lymphomas resistant to conventional therapy. Blood 1993, 82, 2624-2633.

67. Sausville, E.A.; Headlee, D.; Stetler-Stevenson, M.; Jaffe, E.S.; Solomon, D.; Figg, W.D.; Herdt, J.; Kopp, W.C.; Rager, H.; Steinberg, S.M.; et al. Continuous infusion of the anti-CD22 immunotoxin IgG-RFB4-SMPT-dgA in patients with B-cell lymphoma: A phase I study. Blood 1995, 85, 3457-3465.

68. Conry, R.M.; Khazaeli, M.B.; Saleh, M.N.; Ghetie, V.; Vitetta, E.S.; Liu, T.; LoBuglio, A.F. Phase I trial of an anti-CD19 deglycosylated ricin A chain immunotoxin in non-Hodgkin's lymphoma: Effect of an intensive schedule of administration. J. Immunother. Emphasis Tumor Immunol. 1995, 18, 231-241.

69. Stone, M.J.; Sausville, E.A.; Fay, J.W.; Headlee, D.; Collins, R.H.; Figg, W.D.; StetlerStevenson, M.; Jain, V.; Jaffe, E.S.; Solomon, D.; Lush, R.M.; Senderowicz, A.; Ghetie, V.; Schindler, J.; Uhr, J.W.; Vitetta, E.S. A phase I study of bolus versus continuous infusion of the anti-CD19 immunotoxin, IgG-HD37-dgA, in patients with B-cell lymphoma. Blood 1996, 88, 1188-1197.

70. Messmann, R.A.; Vitetta, E.S.; Headlee, D.; Senderowicz, A.M.; Figg, W.D.; Schindler, J.; Michiel, D.F.; Creekmore, S.; Steinberg, S.M.; Kohler, D.; Jaffe, E.S.; Stetler-Stevenson, M.; Chen, H.; Ghetie, V.; Sausville, E.A. A Phase I Study of Combination Therapy with Immunotoxins IgG-HD37-Deglycosylated Ricin A Chain (dgA) and IgG-RFB4-dgA (Combotox) in Patients with Refractory CD19(+), CD22(+) B Cell Lymphoma. Clin. Canc. Res. 2000, 6, 1302-1313.

71. Herrera, L.; Bostrom, B.; Gore, L.; Sandler, E.; Lew, G.; Schlegel, P.G.; Aquino, V.; Ghetie, V.; Vitetta, E.S.; Schindler, J. A phase 1 study of Combotox in pediatric patients with refractory B-lineage acute lymphoblastic leukemia. J. Pediatr. Hematol. Oncol. 2009, 31, 936-941.

72. Engert, A.; Diehl, V.; Schnell, R.; Radszuhn, A.; Hatwig, M.T.; Drillich, S.; Schon, G.; Bohlen, H.; Tesch, H.; Hansmann, M.L.; Barth, S.; Schindler, J.; Ghetie, V.; Uhr, J.; Vitetta, E. A phase-I study of an anti-CD25 ricin A-chain immunotoxin (RFT5-SMPT-dgA) in patients with refractory Hodgkin's lymphoma. Blood 1997, 89, 403-410. 
73. Schnell, R.; Vitetta, E.; Schindler, J.; Barth, S.; Winkler, U.; Borchmann, P.; Hansmann, M.L.; Diehl, V.; Ghetie, V.; Engert, A. Clinical trials with an anti-CD25 ricin A-chain experimental and immunotoxin (RFT5-SMPT-dgA) in Hodgkin's lymphoma. Leuk. Lymphoma 1998, 30, 525-537.

74. Schnell, R.; Vitetta, E.; Schindler, J.; Borchmann, P.; Barth, S.; Ghetie, V.; Hell, K.; Drillich, S.; Diehl, V.; Engert, A. Treatment of refractory Hodgkin's lymphoma patients with an anti-CD25 ricin A-chain immunotoxin. Leukemia 2000, 14, 129-135.

75. Schnell, R.; Borchmann, P.; Staak, J.O.; Schindler, J.; Ghetie, V.; Vitetta, E.S.; Engert, A. Clinical evaluation of ricin A-chain immunotoxins in patients with Hodgkin's lymphoma. Ann. Oncol. 2003, 14, 729-736.

76. Martin, P.J.; Pei, J.; Gooley, T.; Anasetti, C.; Appelbaum, F.R.; Deeg, J.; Hansen, J.A.; Nash, R.A.; Petersdorf, E.W.; Storb, R.; Ghetie, V.; Schindler, J.; Vitetta, E.S. Evaluation of a CD25specific immunotoxin for prevention of graft-versus-host disease after unrelated marrow transplantation. Biol. Blood Marrow Transplant. 2004, 10, 552-560.

77. Schnell, R.; Staak, O.; Borchmann, P.; Schwartz, C.; Matthey, B.r.; Hansen, H.; Schindler, J.; Ghetie, V.; Vitetta, E.S.; Diehl, V.; Engert, A. A Phase I Study with an Anti-CD30 Ricin A-Chain Immunotoxin (Ki-4.dgA) in Patients with Refractory CD30+ Hodgkin's and Non-Hodgkin's Lymphoma. Clin. Canc. Res. 2002, 8, 1779-1786.

78. Grossbard, M.L.; Gribben, J.G.; Freedman, A.S.; Lambert, J.M.; Kinsella, J.; Rabinowe, S.N.; Eliseo, L.; Taylor, J.A.; Blattler, W.A.; Epstein, C.L.; et al. Adjuvant immunotoxin therapy with anti-B4-blocked ricin after autologous bone marrow transplantation for patients with B-cell non-Hodgkin's lymphoma. Blood 1993, 81, 2263-2271.

79. Grossbard, M.L.; Lambert, J.M.; Goldmacher, V.S.; Spector, N.L.; Kinsella, J.; Eliseo, L.; Coral, F.; Taylor, J.A.; Blattler, W.A.; Epstein, C.L.; et al. Anti-B4-blocked ricin: A phase I trial of 7-day continuous infusion in patients with B-cell neoplasms. J. Clin. Oncol. 1993, 11, 726-737.

80. Multani, P.S.; O'Day, S.; Nadler, L.M.; Grossbard, M.L. Phase II clinical trial of bolus infusion anti-B4 blocked ricin immunoconjugate in patients with relapsed B-cell non-Hodgkin's lymphoma. Clin. Canc. Res. 1998, 4, 2599-2604.

81. Grossbard, M.L.; Multani, P.S.; Freedman, A.S.; Ox€ $€^{\mathrm{TM} D a y, ~ S . ; ~ G r i b b e n, ~ J . G . ; ~ R h u d a, ~ C . ; ~}$ Neuberg, D.; Nadler, L.M. A Phase II Study of Adjuvant Therapy with Anti-B4-blocked Ricin after Autologous Bone Marrow Transplantation for Patients with Relapsed B-Cell Non-Hodgkinג $€^{\mathrm{TM}_{\mathrm{S}}}$ Lymphoma. Clin. Canc. Res. 1999, 5, 2392-2398.

82. Zalcberg, J.R.; Pietersz, G.; Toohey, B.; Laird, J.; Huggins, R.; Zimet, A.S.; Hennessy, O.; McKenzie, A.; McKenzie, I.F.C. A phase study of the intralesional injection of ricin-monoclonal antibody conjugates in patients with hepatic metastases. Eur. J. Canc. 1994, 30, 1227-1231.

83. Lynch, T.J., Jr. Immunotoxin therapy of small-cell lung cancer. N901-blocked ricin for relapsed small-cell lung cancer. Chest 1993, 103, 436S-439S.

84. Epstein, C.; Lynch, T.; Shefner, J.; Wen, P.; Maxted, D.; Braman, V.; Ariniello, P.; Coral, F.; Ritz, J. Use of the immunotoxin N901-blocked ricin in patients with small-cell lung cancer. Int. J. Canc. Suppl. 1994, 8, 57-59. 
85. Lynch, T., Jr; Lambert, J.; Coral, F.; Shefner, J.; Wen, P.; Blattler, W.; Collinson, A.; Ariniello, P.; Braman, G.; Cook, S.; Esseltine, D.; Elias, A.; Skarin, A.; Ritz, J. Immunotoxin therapy of small-cell lung cancer: A phase I study of N901- blocked ricin. J. Clin. Oncol. 1997, 15, 723-734.

86. Frankel, A.E.; Laver, J.H.; Willingham, M.C.; Burns, L.J.; Kersey, J.H.; Vallera, D.A. Therapy of Patients with T-cell Lymphomas and Leukemias Using an Anti-CD7 Monoclonal AntibodyRich a Chain Immunotoxin. Leuk. Lymphoma 1997, 26, 287-298.

87. van Oosterhout, Y.V.J.M.; van Emst, L.; Schattenberg, A.V.M.B.; Tax, W.J.M.; Ruiter, D.J.; Spits, H.; Nagengast, F.M.; Masereeuw, R.; Evers, S.; de Witte, T.; Preijers, F.W.M.B. A combination of anti-CD3 and anti-CD7 ricin A-immunotoxins for the in vivo treatment of acute graft versus host disease. Blood 2000, 95, 3693-3701.

88. Skyler, J.S.; Lorenz, T.J.; Schwartz, S.; Eisenbarth, G.S.; Einhorn, D.; Palmer, J.P.; Marks, J.B.; Greenbaum, C.; Saria, E.A.; Byers, V. Effects of an anti-CD5 immunoconjugate (CD5-plus) in recent onset type I diabetes mellitus: A preliminary investigation. The CD5 Diabetes Project Team. J. Diabetes Complicat. 1993, 7, 224-232.

89. Strand, V.; Lipsky, P.E.; Cannon, G.W.; Calabrese, L.H.; Wiesenhutter, C.; Cohen, S.B.; Olsen, N.J.; Lee, M.L.; Lorenz, T.J.; Nelson, B. Effects of administration of an anti-CD5 plus immunoconjugate in rheumatoid arthritis. Results of two phase II studies. The CD5 Plus Rheumatoid Arthritis Investigators Group. Arthritis Rheum. 1993, 36, 620-630.

90. Fishwild, D.M.; Strand, V. Administration of an anti-CD5 immunoconjugate to patients with rheumatoid arthritis: Effect on peripheral blood mononuclear cells and in vitro immune function. J. Rheumatol. 1994, 21, 596-604.

91. Stafford, F.J.; Fleisher, T.A.; Lee, G.; Brown, M.; Strand, V.; Austin, H.A., 3rd; Balow, J.E.; Klippel, J.H. A pilot study of anti-CD5 ricin A chain immunoconjugate in systemic lupus erythematosus. J. Rheumatol. 1994, 21, 2068-2070.

92. Olsen, N.J.; Brooks, R.H.; Cush, J.J.; Lipsky, P.E.; St Clair, E.W.; Matteson, E.L.; Gold, K.N.; Cannon, G.W.; Jackson, C.G.; McCune, W.J.; Fox, D.A.; Nelson, B.; Lorenz, T.; Strand, V. A double-blind, placebo-controlled study of anti-CD5 immunoconjugate in patients with rheumatoid arthritis. The Xoma RA Investigator Group. Arthritis Rheum. 1996, 39, 1102-1108.

93. Kernan, N.A.; Byers, V.; Scannon, P.J.; Mischak, R.P.; Brochstein, J.; Flomenberg, N.; Dupont, B.; O'Reilly, R.J. Treatment of steroid-resistant acute graft-vs-host disease by in vivo administration of an anti-T-cell ricin A chain immunotoxin. JAMA 1988, 259, 3154-3157.

94. Byers, V.; Henslee, P.; Kernan, N.; Blazar, B.; Gingrich, R.; Phillips, G.; LeMaistre, C.; Gilliland, G.; Antin, J.; Martin, P. Use of an anti-pan T-lymphocyte ricin a chain immunotoxin in steroid- resistant acute graft-versus-host disease. Blood 1990, 75, 1426-1432.

95. LeMaistre, C.; Rosen, S.; Frankel, A.; Kornfeld, S.; Saria, E.; Meneghetti, C.; Drajesk, J.; Fishwild, D.; Scannon, P.; Byers, V. Phase I trial of H65-RTA immunoconjugate in patients with cutaneous T- cell lymphoma. Blood 1991, 78, 1173-1182.

96. Laurent, G.; Pris, J.; Farcet, J.; Carayon, P.; Blythman, H.; Casellas, P.; Poncelet, P.; Jansen, F. Effects of therapy with T101 ricin A-chain immunotoxin in two leukemia patients. Blood 1986, $67,1680-1687$. 
97. Hertler, A.A.; Schlossman, D.M.; Borowitz, M.J.; Laurent, G.; Jansen, F.K.; Schmidt, C.; Frankel, A.E. A phase I study of T101-ricin A chain immunotoxin in refractory chronic lymphocytic leukemia. J. Biol. Respon. Mod. 1988, 7, 97-113.

98. Hertler, A.A.; Schlossman, D.M.; Borowitz, M.J.; Blythman, H.E.; Casellas, P.; Frankel, A.E. An anti-CD5 immunotoxin for chronic lymphocytic leukemia: Enhancement of cytotoxicity with human serum albumin-monensin. Int. J. Canc. 1989, 43, 215-219.

99. Castillo, E. MDX-RA Medarex Inc. IDrugs 1998, 1, 476-479.

100. Clark, D.S.; Emery, J.M.; Munsell, M.F. Inhibition of posterior capsule opacification with an immunotoxin specific for lens epithelial cells: 24 month clinical results. J. Cataract Refract. Surg. 1998, 24, 1614-1620.

101. Meacock, W.R.; Spalton, D.J.; Hollick, E.J.; Boyce, J.F.; Barman, S.; Sanguinetti, G. Doublemasked prospective ocular safety study of a lens epithelial cell antibody to prevent posterior capsule opacification. J. Cataract Refract. Surg. 2000, 26, 716-721.

102. Hertler, A.A.; Spitler, L.E.; Frankel, A.E. Humoral immune response to a ricin A chain immunotoxin in patients with metastatic melanoma. Canc. Drug Deliv. 1987, 4, 245-253.

103. Spitler, L.E.; del Rio, M.; Khentigan, A.; Wedel, N.I.; Brophy, N.A.; Miller, L.L.; Harkonen, W.S.; Rosendorf, L.L.; Lee, H.M.; Mischak, R.P.; et al. Therapy of patients with malignant melanoma using a monoclonal antimelanoma antibody-ricin A chain immunotoxin. Canc. Res. 1987, 47, 1717-1723.

104. Mischak, R.P.; Foxall, C.; Rosendorf, L.L.; Knebel, K.; Scannon, P.J.; Spitler, L.E. Human antibody responses to components of the monoclonal antimelanoma antibody ricin A chain immunotoxin XomaZyme-MEL. Mol. Biother. 1990, 2, 104-109.

105. Oratz, R.; Speyer, J.L.; Wernz, J.C.; Hochster, H.; Meyers, M.; Mischak, R.; Spitler, L.E. Antimelanoma monoclonal antibody-ricin A chain immunoconjugate (XMMME-001-RTA) plus cyclophosphamide in the treatment of metastatic malignant melanoma: Results of a phase II trial. J. Biol. Response Mod. 1990, 9, 345-354.

106. Gonzalez, R.; Salem, P.; Bunn, P.A., Jr.; Zukiwski, A.A.; Lamb, R.; Benjamin, R.S.; Spitler, L.; Wedel, N.; Robinson, W.A. Single-dose murine monoclonal antibody ricin A chain immunotoxin in the treatment of metastatic melanoma: A phase I trial. Mol. Biother. 1991, 3, 192-196.

107. Selvaggi, K.; Saria, E.A.; Schwartz, R.; Vlock, D.R.; Ackerman, S.; Wedel, N.; Kirkwood, J.M.; Jones, H.; Ernstoff, M.S. Phase I/II study of murine monoclonal antibody-ricin A chain (XOMAZYME-Mel) immunoconjugate plus cyclosporine $\mathrm{A}$ in patients with metastatic melanoma. J. Immunother. Emphasis Tumor Immunol. 1993, 13, 201-207.

108. Byers, V.S.; Rodvien, R.; Grant, K.; Durrant, L.G.; Hudson, K.H.; Baldwin, R.W.; Scannon, P.J. Phase I study of monoclonal antibody-ricin A chain immunotoxin XomaZyme-791 in patients with metastatic colon cancer. Canc. Res. 1989, 49, 6153-6160.

109. Durrant, L.G.; Byers, V.S.; Scannon, P.J.; Rodvien, R.; Grant, K.; Robins, R.A.; Marksman, R.A.; Baldwin, R.W. Humoral immune responses to XMMCO-791-RTA immunotoxin in colorectal cancer patients. Clin. Exp. Immunol. 1989, 75, 258-264.

110. LoRusso, P.M.; Lomen, P.L.; Redman, B.G.; Poplin, E.; Bander, J.J.; Valdivieso, M. Phase I study of monoclonal antibody-ricin A chain immunoconjugate Xomazyme-791 in patients with metastatic colon cancer. Am. J. Clin. Oncol. 1995, 18, 307-312. 
111. Laske, D.W.; Muraszko, K.M.; Oldfield, E.H.; DeVroom, H.L.; Sung, C.; Dedrick, R.L.; Simon, T.R.; Colandrea, J.; Copeland, C.; Katz, D.; Greenfield, L.; Groves, E.S.; Houston, L.L.; Youle, R.J. Intraventricular immunotoxin therapy for leptomeningeal neoplasia. Neurosurgery 1997, 41, 1039-1049, 1049-1051.

112. Gould, B.J.; Borowitz, M.J.; Groves, E.S.; Carter, P.W.; Anthony, D.; Weiner, L.M.; Frankel, A.E. Phase I study of an anti-breast cancer immunotoxin by continuous infusion: Report of a targeted toxic effect not predicted by animal studies. J. Natl. Canc. Inst. 1989, 81, 775-781.

113. Weiner, L.M.; O'Dwyer, J.; Kitson, J.; Comis, R.L.; Frankel, A.E.; Bauer, R.J.; Konrad, M.S.; Groves, E.S. Phase I evaluation of an anti-breast carcinoma monoclonal antibody 260F9recombinant ricin A chain immunoconjugate. Canc. Res. 1989, 49, 4062-4067.

114. Uckun, F.M. Immunotoxins for the treatment of leukaemia. Br. J. Haematol. 1993, 85, 435-438.

115. Uckun, F.M.; Bellomy, K.; O'Neill, K.; Messinger, Y.; Johnson, T.; Chen, C.-L. Toxicity, Biological Activity, and Pharmacokinetics of TXU (Anti-CD7)-Pokeweed Antiviral Protein in Chimpanzees and Adult Patients Infected with Human Immunodeficiency Virus. J. Pharmacol. Exp. Therapeut. 1999, 291, 1301-1307.

116. Falini, B.; Flenghi, L.; Aversa, F.; Barbabietola, G.; Martelli, M.F.; Comeli, P.; Tazzari, P.L.; Broe, M.K.; Stein, H.; Dürkop, H.; Pizzolo, G.; Bolognesi, A.; Stirpe, F.; Sabattini, E.; Pileri, S. Response of refractory Hodgkin's disease to monoclonal anti-CD30 immunotoxin. The Lancet 1992, 339, 1195-1196.

117. Dean, A.; Talpaz, M.; Kantarjian, H.; Faderl, S.; Jabbour, E.; Ravandi Kashani, F.; O'Brien, S.M.; Rosenblum, M.; Cortes, J.E. Phase I clinical trial of the anti-CD33 immunotoxin HuM195/rgel in patients (pts) with advanced myeloid malignancies. J. Clin. Oncol. 2010, 28, 6549.

118. Yu, L.; Gu, F.; Zhang, C.; Xie, S.; Guo, Y. Targeted diagnosis and treatment of superficial bladder cancer with monoclonal antibody BDI-1. Chin. Med. J. (Engl.) 1998, 111, 404-407.

119. Menestrina, G.; Schiavo, G.; Montecucco, C. Molecular mechanisms of action of bacterial protein toxins. Mol. Aspect. Med. 1994, 15, 79-193.

120. Falnes, P.O.; Sandvig, K. Penetration of protein toxins into cells. Curr. Opin. Cell Biol. 2000, 12, 407-413.

121. Choe, S.; Bennett, M.J.; Fujii, G.; Curmi, P.M.; Kantardjieff, K.A.; Collier, R.J.; Eisenberg, D. The crystal structure of diphtheria toxin. Nature 1992, 357, 216-222.

122. Tsuneoka, M.; Nakayama, K.; Hatsuzawa, K.; Komada, M.; Kitamura, N.; Mekada, E. Evidence for involvement of furin in cleavage and activation of diphtheria toxin. J. Biol. Chem. 1993, 268, 26461-26465.

123. Chiron, M.F.; Fryling, C.M.; FitzGerald, D.J. Cleavage of pseudomonas exotoxin and diphtheria toxin by a furin-like enzyme prepared from beef liver. J. Biol. Chem. 1994, 269, 18167-18176.

124. Donovan, J.J.; Simon, M.I.; Draper, R.K.; Montal, M. Diphtheria toxin forms transmembrane channels in planar lipid bilayers. Proc. Natl. Acad. Sci. USA 1981, 78, 172-176.

125. Kagan, B.L.; Finkelstein, A.; Colombini, M. Diphtheria toxin fragment forms large pores in phospholipid bilayer membranes. Proc. Natl. Acad. Sci. USA 1981, 78, 4950-4954.

126. Lemichez, E.; Bomsel, M.; Devilliers, G.; vanderSpek, J.; Murphy, J.R.; Lukianov, E.V.; Olsnes, S.; Boquet, P. Membrane translocation of diphtheria toxin fragment A exploits early to late endosome trafficking machinery. Mol. Microbiol. 1997, 23, 445-457. 
127. Ratts, R.; Zeng, H.; Berg, E.A.; Blue, C.; McComb, M.E.; Costello, C.E.; vanderSpek, J.C.; Murphy, J.R. The cytosolic entry of diphtheria toxin catalytic domain requires a host cell cytosolic translocation factor complex. J. Cell Biol. 2003, 160, 1139-1150.

128. Trujillo, C.; Ratts, R.; Tamayo, A.; Harrison, R.; Murphy, J.R. Trojan horse or proton force: Finding the right partner(s) for toxin translocation. Neurotox. Res. 2006, 9, 63-71.

129. Trujillo, C.; Taylor-Parker, J.; Harrison, R.; Murphy, J.R. Essential lysine residues within transmembrane helix 1 of diphtheria toxin facilitate COPI binding and catalytic domain entry. Mol. Microbiol. 2010, 76, 1010-1019.

130. Morimoto, H.; Bonavida, B. Diphtheria toxin- and Pseudomonas A toxin-mediated apoptosis. ADP ribosylation of elongation factor-2 is required for DNA fragmentation and cell lysis and synergy with tumor necrosis factor-alpha. J. Immunol. 1992, 149, 2089-2094.

131. Thorburn, J.; Frankel, A.E.; Thorburn, A. Apoptosis by leukemia cell-targeted diphtheria toxin occurs via receptor-independent activation of Fas-associated death domain protein. Clin. Canc. Res. 2003, 9, 861-865.

132. Thorburn, A.; Thorburn, J.; Frankel, A.E. Induction of apoptosis by tumor cell-targeted toxins. Apoptosis 2004, 9, 19-25.

133. Deng, Q.; Barbieri, J.T. Molecular mechanisms of the cytotoxicity of ADP-ribosylating toxins. Annu. Rev. Microbiol. 2008, 62, 271-288.

134. Yamaizumi, M.; Mekada, E.; Uchida, T.; Okada, Y. One molecule of diphtheria toxin fragment A introduced into a cell can kill the cell. Cell 1978, 15, 245-250.

135. Strauchen, J.A.; Breakstone, B.A. IL-2 receptor expression in human lymphoid lesions. Immunohistochemical study of 166 cases. Am. J. Pathol. 1987, 126, 506-512.

136. Strauchen, J.A. Interleukin receptors in lymphoid lesions. Relevance to diagnosis, biology, and therapy. Pathol. Annu. 1989, 24, 149-165.

137. Kodaka, T.; Uchiyama, T.; Ishikawa, T.; Kamio, M.; Onishi, R.; Itoh, K.; Hori, T.; Uchino, H.; Tsudo, M.; Araki, K. Interleukin-2 receptor beta-chain (p70-75) expressed on leukemic cells from adult T cell leukemia patients. Jpn. J. Canc. Res. 1990, 81, 902-908.

138. Yagura, H.; Tamaki, T.; Furitsu, T.; Tomiyama, Y.; Nishiura, T.; Tominaga, N.; Katagiri, S.; Yonezawa, T.; Tarui, S. Demonstration of high-affinity interleukin-2 receptors on B-chronic lymphocytic leukemia cells: Functional and structural characterization. Blut 1990, 60, 181-186.

139. Re, G.G.; Waters, C.; Poisson, L.; Willingham, M.C.; Sugamura, K.; Frankel, A.E. Interleukin 2 (IL-2) receptor expression and sensitivity to diphteria fusion toxin DAB389IL-2 in cultured hematopoietic cells. Canc. Res. 1996, 56, 2590-2595.

140. Williams, D.P.; Snider, C.E.; Strom, T.B.; Murphy, J.R. Structure/function analysis of interleukin-2-toxin (DAB486-IL-2). Fragment B sequences required for the delivery of fragment A to the cytosol of target cells. J. Biol. Chem. 1990, 265, 11885-11889.

141. LeMaistre, C.F.; Saleh, M.N.; Kuzel, T.M.; Foss, F.; Platanias, L.C.; Schwartz, G.; Ratain, M.; Rook, A.; Freytes, C.O.; Craig, F.; Reuben, J.; Nichols, J.C. Phase I trial of a ligand fusionprotein (DAB389IL-2) in lymphomas expressing the receptor for interleukin-2. Blood 1998, 91, $399-405$. 
142. McGinnis, K.S.; Shapiro, M.; Junkins-Hopkins, J.M.; Smith, M.; Lessin, S.R.; Vittorio, C.C.; Rook, A.H. Denileukin diftitox for the treatment of panniculitic lymphoma. Arch. Dermatol. 2002, 138, 740-742.

143. Martin, A.; Gutierrez, E.; Muglia, J.; McDonald, C.J.; Guzzo, C.; Gottlieb, A.; Pappert, A.; Garland, W.T.; Bagel, J.; Bacha, P. A multicenter dose-escalation trial with denileukin diftitox (ONTAK, DAB(389)IL-2) in patients with severe psoriasis. J. Am. Acad. Dermatol. 2001, 45, 871-881.

144. Kelleher, C.A.; Wong, G.G.; Clark, S.C.; Schendel, P.F.; Minden, M.D.; McCulloch, E.A. Binding of iodinated recombinant human GM-CSF to the blast cells of acute myeloblastic leukemia. Leukemia 1988, 2, 211-215.

145. Frankel, A.E.; Hall, P.D.; Burbage, C.; Vesely, J.; Willingham, M.; Bhalla, K.; Kreitman, R.J. Modulation of the apoptotic response of human myeloid leukemia cells to a diphtheria toxin granulocyte-macrophage colony-stimulating factor fusion protein. Blood 1997, 90, 3654-3661.

146. Kreitman, R.J.; Pastan, I. Recombinant toxins containing human granulocyte-macrophage colony-stimulating factor and either pseudomonas exotoxin or diphtheria toxin kill gastrointestinal cancer and leukemia cells. Blood 1997, 90, 252-259.

147. Recht, L.; Torres, C.O.; Smith, T.W.; Raso, V.; Griffin, T.W. Transferrin receptor in normal and neoplastic brain tissue: Implications for brain-tumor immunotherapy. J. Neurosurg. 1990, 72, 941-945.

148. Greenfield, L.; Johnson, V.G.; Youle, R.J. Mutations in diphtheria toxin separate binding from entry and amplify immunotoxin selectivity. Science 1987, 238, 536-539.

149. Johnson, V.G.; Wrobel, C.; Wilson, D.; Zovickian, J.; Greenfield, L.; Oldfield, E.H.; Youle, R. Improved tumor-specific immunotoxins in the treatment of CNS and leptomeningeal neoplasia. J. Neurosurg. 1989, 70, 240-248.

150. Liu, P.V. Extracellular toxins of Pseudomonas aeruginosa. J. Infect. Dis. 1974, 130, S94-S99.

151. Iglewski, B.H.; Kabat, D. NAD-dependent inhibition of protein synthesis by Pseudomonas aeruginosa toxin. Proc. Natl. Acad. Sci. USA 1975, 72, 2284-2288.

152. Hwang, J.; Fitzgerald, D.J.; Adhya, S.; Pastan, I. Functional domains of Pseudomonas exotoxin identified by deletion analysis of the gene expressed in E. coli. Cell 1987, 48, 129-136.

153. Siegall, C.B.; Chaudhary, V.K.; FitzGerald, D.J.; Pastan, I. Functional analysis of domains II, Ib, and III of Pseudomonas exotoxin. J. Biol. Chem. 1989, 264, 14256-14261.

154. Hessler, J.L.; Kreitman, R.J. An early step in Pseudomonas exotoxin action is removal of the terminal lysine residue, which allows binding to the KDEL receptor. Biochemistry 1997, 36, $14577-14582$.

155. Kounnas, M.Z.; Morris, R.E.; Thompson, M.R.; FitzGerald, D.J.; Strickland, D.K.; Saelinger, C.B. The alpha 2-macroglobulin receptor/low density lipoprotein receptor-related protein binds and internalizes Pseudomonas exotoxin A. J. Biol. Chem. 1992, 267, 12420-12423.

156. Smith, D.C.; Spooner, R.A.; Watson, P.D.; Murray, J.L.; Hodge, T.W.; Amessou, M.; Johannes, L.; Lord, J.M.; Roberts, L.M. Internalized Pseudomonas exotoxin A can exploit multiple pathways to reach the endoplasmic reticulum. Traffic 2006, 7, 379-393.

157. Fryling, C.; Ogata, M.; FitzGerald, D. Characterization of a cellular protease that cleaves Pseudomonas exotoxin. Infect. Immun. 1992, 60, 497-502. 
158. Ogata, M.; Fryling, C.M.; Pastan, I.; FitzGerald, D.J. Cell-mediated cleavage of Pseudomonas exotoxin between Arg279 and Gly280 generates the enzymatically active fragment which translocates to the cytosol. J. Biol. Chem. 1992, 267, 25396-25401.

159. McKee, M.L.; FitzGerald, D.J. Reduction of furin-nicked Pseudomonas exotoxin A: An unfolding story. Biochemistry 1999, 38, 16507-16513.

160. Lombardi, D.; Soldati, T.; Riederer, M.A.; Goda, Y.; Zerial, M.; Pfeffer, S.R. Rab9 functions in transport between late endosomes and the trans Golgi network. EMBO J. 1993, 12, 677-682.

161. Chaudhary, V.K.; Jinno, Y.; FitzGerald, D.; Pastan, I. Pseudomonas exotoxin contains a specific sequence at the carboxyl terminus that is required for cytotoxicity. Proc. Natl. Acad. Sci. USA 1990, 87, 308-312.

162. Kreitman, R.J.; Pastan, I. Importance of the glutamate residue of KDEL in increasing the cytotoxicity of Pseudomonas exotoxin derivatives and for increased binding to the KDEL receptor. Biochem. J. 1995, 307, 29-37.

163. Jackson, M.E.; Simpson, J.C.; Girod, A.; Pepperkok, R.; Roberts, L.M.; Lord, J.M. The KDEL retrieval system is exploited by Pseudomonas exotoxin A, but not by Shiga-like toxin-1, during retrograde transport from the Golgi complex to the endoplasmic reticulum. J. Cell. Sci. 1999, $112,467-475$.

164. Ogata, M.; Chaudhary, V.K.; Pastan, I.; FitzGerald, D.J. Processing of Pseudomonas exotoxin by a cellular protease results in the generation of a 37,000-Da toxin fragment that is translocated to the cytosol. J. Bio.l Chem. 1990, 265, 20678-20685.

165. Theuer, C.P.; Buchner, J.; FitzGerald, D.; Pastan, I. The N-terminal region of the 37-kDa translocated fragment of Pseudomonas exotoxin A aborts translocation by promoting its own export after microsomal membrane insertion. Proc. Natl. Acad. Sci. USA 1993, 90, 7774-7778.

166. Theuer, C.; Kasturi, S.; Pastan, I. Domain II of Pseudomonas exotoxin A arrests the transfer of translocating nascent chains into mammalian microsomes. Biochemistry 1994, 33, 5894-5900.

167. Hazes, B.; Read, R.J. Accumulating evidence suggests that several AB-toxins subvert the endoplasmic reticulum-associated protein degradation pathway to enter target cells. Biochemistry 1997, 36, 11051-11054.

168. Koopmann, J.O.; Albring, J.; Huter, E.; Bulbuc, N.; Spee, P.; Neefjes, J.; Hammerling, G.J.; Momburg, F. Export of antigenic peptides from the endoplasmic reticulum intersects with retrograde protein translocation through the Sec61p channel. Immunity 2000, 13, 117-127.

169. Spooner, R.A.; Smith, D.C.; Easton, A.J.; Roberts, L.M.; Lord, J.M. Retrograde transport pathways utilised by viruses and protein toxins. Virol. J. 2006, 3, 26.

170. Iglewski, B.H.; Liu, P.V.; Kabat, D. Mechanism of action of Pseudomonas aeruginosa exotoxin Aiadenosine diphosphate-ribosylation of mammalian elongation factor 2 in vitro and in vivo. Infect. Immun. 1977, 15, 138-144.

171. Carroll, S.F.; Collier, R.J. Active site of Pseudomonas aeruginosa exotoxin A. Glutamic acid 553 is photolabeled by NAD and shows functional homology with glutamic acid 148 of diphtheria toxin. J. Biol. Chem. 1987, 262, 8707-8711.

172. Jenkins, C.E.; Swiatoniowski, A.; Issekutz, A.C.; Lin, T.J. Pseudomonas aeruginosa exotoxin A induces human mast cell apoptosis by a caspase- 8 and -3-dependent mechanism. J. Biol. Chem. 2004, 279, 37201-37207. 
173. Wolf, P.; Elsasser-Beile, U. Pseudomonas exotoxin A: From virulence factor to anti-cancer agent. Int. J. Med. Microbiol. 2009, 299, 161-176.

174. Uchiyama, T.; Broder, S.; Waldmann, T.A. A monoclonal antibody (anti-Tac) reactive with activated and functionally mature human T cells. I. Production of anti-Tac monoclonal antibody and distribution of Tac (+) cells. J. Immunol. 1981, 126, 1393-1397.

175. Uchiyama, T.; Nelson, D.L.; Fleisher, T.A.; Waldmann, T.A. A monoclonal antibody (anti-Tac) reactive with activated and functionally mature human T cells. II. Expression of Tac antigen on activated cytotoxic killer $\mathrm{T}$ cells, suppressor cells, and on one of two types of helper $\mathrm{T}$ cells. J. Immunol. 1981, 126, 1398-1403.

176. Waldmann, T.A. Anti-Tac (daclizumab, Zenapax) in the treatment of leukemia, autoimmune diseases, and in the prevention of allograft rejection: A 25-year personal odyssey. J. Clin. Immunol. 2007, 27, 1-18.

177. Kreitman, R.J.; Bailon, P.; Chaudhary, V.K.; FitzGerald, D.J.; Pastan, I. Recombinant immunotoxins containing anti-Tac(Fv) and derivatives of Pseudomonas exotoxin produce complete regression in mice of an interleukin-2 receptor-expressing human carcinoma. Blood 1994, 83, 426-434.

178. Kreitman, R.J.; Pastan, I. Accumulation of a recombinant immunotoxin in a tumor in vivo: Fewer than 1000 molecules per cell are sufficient for complete responses. Canc. Res. 1998, 58, 968-975.

179. Robbins, D.H.; Margulies, I.; Stetler-Stevenson, M.; Kreitman, R.J. Hairy cell leukemia, a B-cell neoplasm that is particularly sensitive to the cytotoxic effect of anti-Tac(Fv)-PE38 (LMB-2). Clin Canc. Res. 2000, 6, 693-700.

180. Onda, M.; Kreitman, R.J.; Vasmatzis, G.; Lee, B.; Pastan, I. Reduction of the nonspecific animal toxicity of anti-Tac(Fv)-PE38 by mutations in the framework regions of the Fv which lower the isoelectric point. J. Immunol. 1999, 163, 6072-6077.

181. Kreitman, R.J. Recombinant immunotoxins for the treatment of haematological malignancies. Expert Opin. Biol. Ther. 2004, 4, 1115-1128.

182. Onda, M.; Willingham, M.; Wang, Q.C.; Kreitman, R.J.; Tsutsumi, Y.; Nagata, S.; Pastan, I. Inhibition of TNF-alpha produced by Kupffer cells protects against the nonspecific liver toxicity of immunotoxin anti-Tac(Fv)-PE38, LMB-2. J. Immunol. 2000, 165, 7150-7156.

183. Chakraborty, N.G.; Chattopadhyay, S.; Mehrotra, S.; Chhabra, A.; Mukherji, B. Regulatory T-cell response and tumor vaccine-induced cytotoxic $\mathrm{T}$ lymphocytes in human melanoma. Hum. Immunol. 2004, 65, 794-802.

184. Powell, D.J., Jr.; Felipe-Silva, A.; Merino, M.J.; Ahmadzadeh, M.; Allen, T.; Levy, C.; White, D.E.; Mavroukakis, S.; Kreitman, R.J.; Rosenberg, S.A.; Pastan, I. Administration of a CD25directed immunotoxin, LMB-2, to patients with metastatic melanoma induces a selective partial reduction in regulatory T cells in vivo. J. Immunol. 2007, 179, 4919-4928.

185. Clark, E.A. CD22, a B cell-specific receptor, mediates adhesion and signal transduction. J. Immunol. 1993, 150, 4715-4718.

186. Robbins, B.A.; Ellison, D.J.; Spinosa, J.C.; Carey, C.A.; Lukes, R.J.; Poppema, S.; Saven, A.; Piro, L.D. Diagnostic application of two-color flow cytometry in 161 cases of hairy cell leukemia. Blood 1993, 82, 1277-1287. 
187. Gudowius, S.; Recker, K.; Laws, H.J.; Dirksen, U.; Troger, A.; Wieczorek, U.; Furlan, S.; Gobel, U.; Hanenberg, H. Identification of candidate target antigens for antibody-based immunotherapy in childhood B-cell precursor ALL. Klin. Padiatr. 2006, 218, 327-333.

188. Olejniczak, S.H.; Stewart, C.C.; Donohue, K.; Czuczman, M.S. A quantitative exploration of surface antigen expression in common B-cell malignancies using flow cytometry. Immunol. Invest. 2006, 35, 93-114.

189. Rawstron, A.C.; de Tute, R.; Jack, A.S.; Hillmen, P. Flow cytometric protein expression profiling as a systematic approach for developing disease-specific assays: Identification of a chronic lymphocytic leukaemia-specific assay for use in rituximab-containing regimens. Leukemia 2006, 20, 2102-2110.

190. Campana, D.; Janossy, G.; Bofill, M.; Trejdosiewicz, L.K.; Ma, D.; Hoffbrand, A.V.; Mason, D.Y.; Lebacq, A.M.; Forster, H.K. Human B cell development. I. Phenotypic differences of B lymphocytes in the bone marrow and peripheral lymphoid tissue. J. Immunol. 1985, 134, $1524-1530$.

191. Mansfield, E.; Amlot, P.; Pastan, I.; FitzGerald, D.J. Recombinant RFB4 immunotoxins exhibit potent cytotoxic activity for CD22-bearing cells and tumors. Blood 1997, 90, 2020-2026.

192. Robak T. Current treatment options in hairy cell leukemia and hairy cell leukemia variant. Canc. Treat. Rev. 2006, 32, 365-376.

193. Kreitman, R.J.; Pastan, I. Immunotoxins in the treatment of hematologic malignancies. Curr. Drug Targets. 2006, 7, 1301-1311.

194. Kreitman, R.J. Recombinant immunotoxins for the treatment of chemoresistant hematologic malignancies. Curr. Pharm. Des. 2009, 15, 2652-2664.

195. Sakamoto, J.; Furukawa, K.; Cordon-Cardo, C.; Yin, B.W.; Rettig, W.J.; Oettgen, H.F.; Old, L.J.; Lloyd, K.O. Expression of Lewisa, Lewisb, X, and Y blood group antigens in human colonic tumors and normal tissue and in human tumor-derived cell lines. Canc. Res. 1986, 46, $1553-1561$.

196. Miyake, M.; Taki, T.; Hitomi, S.; Hakomori, S. Correlation of expression of H/Le(y)/Le(b) antigens with survival in patients with carcinoma of the lung. N. Engl. J. Med. 1992, 327, 14-18.

197. Yin, B.W.; Finstad, C.L.; Kitamura, K.; Federici, M.G.; Welshinger, M.; Kudryashov, V.; Hoskins, W.J.; Welt, S.; Lloyd, K.O. Serological and immunochemical analysis of Lewis y (Ley) blood group antigen expression in epithelial ovarian cancer. Int. J. Cancer. 1996, 65, 406-412.

198. Pastan, I.; Lovelace, E.T.; Gallo, M.G.; Rutherford, A.V.; Magnani, J.L.; Willingham, M.C. Characterization of monoclonal antibodies $\mathrm{B} 1$ and $\mathrm{B} 3$ that react with mucinous adenocarcinomas. Canc. Res. 1991, 51, 3781-3787.

199. Kuan, C.T.; Pai, L.H.; Pastan, I. Immunotoxins containing Pseudomonas exotoxin that target LeY damage human endothelial cells in an antibody-specific mode: Relevance to vascular leak syndrome. Clin. Canc. Res. 1995, 1, 1589-1594.

200. Posey, J.A.; Khazaeli, M.B.; Bookman, M.A.; Nowrouzi, A.; Grizzle, W.E.; Thornton, J.; Carey, D.E.; Lorenz, J.M.; Sing, A.P.; Siegall, C.B.; LoBuglio, A.F.; Saleh, M.N. A phase I trial of the single-chain immunotoxin SGN-10 (BR96 sFv-PE40) in patients with advanced solid tumors. Clin. Canc. Res. 2002, 8, 3092-3099. 
201. Nielsen, K.; Boston, R.S. Ribosome-inactivating proteins: A plant perspective. Annu. Rev. Plant. Physiol. Plant. Mol. Biol. 2001, 52, 785-816.

202. Peumans, W.J.; Hao, Q.; Van Damme, E.J. Ribosome-inactivating proteins from plants: More than RNA N-glycosidases? FASEB J. 2001, 15, 1493-1506.

203. Van Damme, E.J.M.; Hao, Q.; Chen, Y.; Barre, A.; Vandenbussche, F.; Desmyter, S.; Rouge, P.; Peumans, W.J. Ribosome-inactivating proteins: A family of plant proteins that do more than inactivate ribosomes. Crit. Rev. Plant Sci. 2001, 20, 395-466.

204. Girbes, T.; Ferreras, J.M.; Arias, F.J.; Stirpe, F. Description, distribution, activity and phylogenetic relationship of ribosome-inactivating proteins in plants, fungi and bacteria. Mini Rev. Med. Chem. 2004, 4, 461-476.

205. Hartley, M.R.; Lord, J.M. Cytotoxic ribosome-inactivating lectins from plants. Biochim. Biophys. Acta 2004, 1701, 1-14.

206. Stirpe, F. Ribosome-inactivating proteins. Toxicon 2004, 44, 371-383.

207. Stirpe, F.; Battelli, M.G. Ribosome-inactivating proteins: Progress and problems. Cell Mol. Life Sci. 2006, 63, 1850-1866.

208. Reinbothe, S.; Reinbothe, C.; Lehmann, J.; Becker, W.; Apel, K.; Parthier, B. JIP60, a methyl jasmonate-induced ribosome-inactivating protein involved in plant stress reactions. Proc. Natl. Acad. Sci. USA 1994, 91, 7012-7016.

209. Stirpe, F.; Barbieri, L.; Gorini, P.; Valbonesi, P.; Bolognesi, A.; Polito, L. Activities associated with the presence of ribosome-inactivating proteins increase in senescent and stressed leaves. FEBS Lett. 1996, 382, 309-312.

210. Rippmann, J.F.; Michalowski, C.B.; Nelson, D.E.; Bohnert, H.J. Induction of a ribosomeinactivating protein upon environmental stress. Plant. Mol. Biol. 1997, 35, 701-709.

211. Cola, A.D.; Poma, A.; Spanò, L. Culture senescence and abscisic acid induce saporin production in cultured roots of Saponaria officinalis. New Phytol. 1999, 141, 381-386.

212. Song, S.K.; Choi, Y.; Moon, Y.H.; Kim, S.G.; Choi, Y.D.; Lee, J.S. Systemic induction of a Phytolacca insularis antiviral protein gene by mechanical wounding, jasmonic acid, and abscisic acid. Plant Mol. Biol. 2000, 43, 439-450.

213. Bass, H.W.; Krawetz, J.E.; GR, O.B.; Zinselmeier, C.; Habben, J.E.; Boston, R.S. Maize ribosome-inactivating proteins (RIPs) with distinct expression patterns have similar requirements for proenzyme activation. J. Exp. Bot. 2004, 55, 2219-2233.

214. Qin, W.; Ming-Xing, H.; Ying, X.; Xin-Shen, Z.; Fang, C. Expression of a ribosome inactivating protein (curcin 2) in Jatropha curcas is induced by stress. J. Biosci. 2005, 30, 351-357.

215. Girbes, T.; de Torre, C.; Iglesias, R.; Miguel Ferreras, J.; Mendez, E. RIP for viruses. Nature 1996, 379, 777-778.

216. Iglesias, R.; Perez, Y.; de Torre, C.; Ferreras, J.M.; Antolin, P.; Jimenez, P.; Rojo, M.A.; Mendez, E.; Girbes, T. Molecular characterization and systemic induction of single-chain ribosome-inactivating proteins (RIPs) in sugar beet (Beta vulgaris) leaves. J. Exp. Bot. 2005, 56, 1675-1684.

217. Xu, J.; Wang, H.; Fan, J. Expression of a ribosome-inactivating protein gene in bitter melon is induced by Sphaerotheca fuliginea and abiotic stimuli. Biotechnol. Lett. 2007, 29, 1605-1610. 
218. Walsh, T.A.; Morgan, A.E.; Hey, T.D. Characterization and molecular cloning of a proenzyme form of a ribosome-inactivating protein from maize. Novel mechanism of proenzyme activation by proteolytic removal of a 2.8-kilodalton internal peptide segment. J. Biol. Chem. 1991, 266, 23422-23427.

219. Bass, H.W.; Webster, C.; GR, O.B.; Roberts, J.K.; Boston, R.S. A maize ribosome-inactivating protein is controlled by the transcriptional activator Opaque-2. Plant Cell 1992, 4, 225-234.

220. Chaudhry, B.; Muller-Uri, F.; Cameron-Mills, V.; Gough, S.; Simpson, D.; Skriver, K.; Mundy, J. The barley $60 \mathrm{kDa}$ jasmonate-induced protein (JIP60) is a novel ribosome-inactivating protein. Plant J. 1994, 6, 815-824.

221. Nicolson, G.L.; Blaustein, J. The interaction of Ricinus communis agglutinin with normal and tumor cell surfaces. Biochim. Biophys. Acta. 1972, 266, 543-547.

222. Nicolson, G.L. The interactions of lectins with animal cell surfaces. Int. Rev. Cytol. 1974, 39, 89-190.

223. Nicolson, G.L. Ultrastructural analysis of toxin binding and entry into mammalian cells. Nature 1974, 251, 628-630.

224. Baenziger, J.U.; Fiete, D. Structural determinants of Ricinus communis agglutinin and toxin specificity for oligosaccharides. J. Biol. Chem. 1979, 254, 9795-9799.

225. Houston, L.L.; Dooley, T.P. Binding of two molecules of 4-methylumbelliferyl galactose or 4-methylumbelliferyl N-acetylgalactosamine to the B chains of ricin and Ricinus communis agglutinin and to purified ricin B chain. J. Biol. Chem. 1982, 257, 4147-4151.

226. Hughes, R.C.; Mills, G. Analysis by lectin affinity chromatography of N-linked glycans of BHK cells and ricin-resistant mutants. Biochem. J. 1983, 211, 575-587.

227. Skilleter, D.N.; Paine, A.J.; Stirpe, F. A comparison of the accumulation of ricin by hepatic parenchymal and non-parenchymal cells and its inhibition of protein synthesis. Biochim. Biophys. Acta 1981, 677, 495-500.

228. Simmons, B.M.; Stahl, P.D.; Russell, J.H. Mannose receptor-mediated uptake of ricin toxin and ricin A chain by macrophages. Multiple intracellular pathways for a chain translocation. J. Biol. Chem. 1986, 261, 7912-7920.

229. Magnusson, S.; Berg, T.; Turpin, E.; Frenoy, J.P. Interactions of ricin with sinusoidal endothelial rat liver cells. Different involvement of two distinct carbohydrate-specific mechanisms in surface binding and internalization. Biochem. J. 1991, 277, 855-861.

230. Magnusson, S.; Kjeken, R.; Berg, T. Characterization of two distinct pathways of endocytosis of ricin by rat liver endothelial cells. Exp. Cell. Res. 1993, 205, 118-125.

231. Riccobono, F.; Fiani, M.L. Mannose receptor dependent uptake of ricin A1 and A2 chains by macrophages. Carbohydr. Res. 1996, 282, 285-292.

232. Frankel, A.E.; Fu, T.; Burbage, C.; Tagge, E.; Harris, B.; Vesely, J.; Willingham, M.C. Lectindeficient ricin toxin intoxicates cells bearing the D-mannose receptor. Carbohydr. Res. 1997, 300, 251-258.

233. Rapak, A.; Falnes, P.O.; Olsnes, S. Retrograde transport of mutant ricin to the endoplasmic reticulum with subsequent translocation to cytosol. Proc. Natl. Acad. Sci. USA 1997, 94, 3783-3788. 
234. Sandvig, K.; van Deurs, B. Endocytosis and intracellular transport of ricin: Recent discoveries. FEBS Lett. 1999, 452, 67-70.

235. Simpson, J.C.; Roberts, L.M.; Romisch, K.; Davey, J.; Wolf, D.H.; Lord, J.M. Ricin A chain utilises the endoplasmic reticulum-associated protein degradation pathway to enter the cytosol of yeast. FEBS Lett. 1999, 459, 80-84.

236. Wesche, J.; Rapak, A.; Olsnes, S. Dependence of ricin toxicity on translocation of the toxin A-chain from the endoplasmic reticulum to the cytosol. J. Biol. Chem. 1999, 274, 34443-34449.

237. Deeks, E.D.; Cook, J.P.; Day, P.J.; Smith, D.C.; Roberts, L.M.; Lord, J.M. The low lysine content of ricin A chain reduces the risk of proteolytic degradation after translocation from the endoplasmic reticulum to the cytosol. Biochemistry 2002, 41, 3405-3413.

238. Wesche, J. Retrograde transport of ricin. Int. J. Med. Microbiol. 2002, 291, 517-521.

239. Lord, J.M.; Deeks, E.; Marsden, C.J.; Moore, K.; Pateman, C.; Smith, D.C.; Spooner, R.A.; Watson, P.; Roberts, L.M. Retrograde transport of toxins across the endoplasmic reticulum membrane. Biochem. Soc. Trans. 2003, 31, 1260-1262.

240. Roberts, L.M.; Lord, J.M. Ribosome-inactivating proteins: Entry into mammalian cells and intracellular routing. Mini Rev. Med. Chem. 2004, 4, 505-512.

241. Spooner, R.A.; Watson, P.D.; Marsden, C.J.; Smith, D.C.; Moore, K.A.; Cook, J.P.; Lord, J.M.; Roberts, L.M. Protein disulphide-isomerase reduces ricin to its $\mathrm{A}$ and $\mathrm{B}$ chains in the endoplasmic reticulum. Biochem. J. 2004, 383, 285-293.

242. Vago, R.; Marsden, C.J.; Lord, J.M.; Ippoliti, R.; Flavell, D.J.; Flavell, S.U.; Ceriotti, A.; Fabbrini, M.S. Saporin and ricin A chain follow different intracellular routes to enter the cytosol of intoxicated cells. FEBS J. 2005, 272, 4983-4995.

243. Cavallaro, U.; Nykjaer, A.; Nielsen, M.; Soria, M.R. Alpha 2-macroglobulin receptor mediates binding and cytotoxicity of plant ribosome-inactivating proteins. Eur. J. Biochem. 1995, 232, $165-171$.

244. Cavallaro, U.; Soria, M.R. Targeting plant toxins to the urokinase and alpha 2-macroglobulin receptors. Semin. Canc. Biol. 1995, 6, 269-278.

245. Chan, W.L.; Shaw, P.C.; Tam, S.C.; Jacobsen, C.; Gliemann, J.; Nielsen, M.S. Trichosanthin interacts with and enters cells via LDL receptor family members. Biochem. Biophys. Res. Commun. 2000, 270, 453-457.

246. Stirpe, F.; Olsnes, S.; Pihl, A. Gelonin, a new inhibitor of protein synthesis, nontoxic to intact cells. Isolation, characterization, and preparation of cytotoxic complexes with concanavalin A. J. Biol. Chem. 1980, 255, 6947-6953.

247. Bolognesi, A.; Tazzari, P.L.; Tassi, C.; Gromo, G.; Gobbi, M.; Stirpe, F. A comparison of anti-lymphocyte immunotoxins containing different ribosome-inactivating proteins and antibodies. Clin. Exp. Immunol. 1992, 89, 341-346.

248. Bolognesi, A.; Polito, L. Immunotoxins and other conjugates: Pre-clinical studies. Mini Rev. Med. Chem. 2004, 4, 563-583.

249. Fracasso, G.; Bellisola, G.; Castelletti, D.; Tridente, G.; Colombatti, M. Immunotoxins and other conjugates: Preparation and general characteristics. Mini Rev. Med. Chem. 2004, 4, 545-562. 
250. Geden, S.E.; Gardner, R.A.; Fabbrini, M.S.; Ohashi, M.; Phanstiel Iv, O.; Teter, K. Lipopolyamine treatment increases the efficacy of intoxication with saporin and anticancer saporin conjugate. FEBS J. 2007, 274, 4825-4836.

251. Endo, Y.; Tsurugi, K. The RNA N-glycosidase activity of ricin A-chain. The characteristics of the enzymatic activity of ricin A-chain with ribosomes and with rRNA. J. Biol. Chem. 1988, 263, $8735-8739$.

252. Endo, Y.; Tsurugi, K.; Lambert, J.M. The site of action of six different ribosome-inactivating proteins from plants on eukaryotic ribosomes: The RNA N-glycosidase activity of the proteins. Biochem. Biophys. Res. Commun. 1988, 150, 1032-1036.

253. Stirpe, F.; Bailey, S.; Miller, S.P.; Bodley, J.W. Modification of ribosomal RNA by ribosomeinactivating proteins from plants. Nucl. Acid. Res. 1988, 16, 1349-1357.

254. Montanaro, L.; Sperti, S.; Mattioli, A.; Testoni, G.; Stirpe, F. Inhibition by ricin of protein synthesis in vitro. Inhibition of the binding of elongation factor 2 and of adenosine diphosphateribosylated elongation factor 2 to ribosomes. Biochem. J. 1975, 146, 127-131.

255. Nilsson, L.; Asano, K.; Svensson, B.; Poulsen, F.M.; Nygard, O. Reduced turnover of the elongation factor EF-1 X ribosome complex after treatment with the protein synthesis inhibitor II from barley seeds. Biochim. Biophys. Acta 1986, 868, 62-70.

256. Griffiths, G.D.; Leek, M.D.; Gee, D.J. The toxic plant proteins ricin and abrin induce apoptotic changes in mammalian lymphoid tissues and intestine. J. Pathol. 1987, 151, 221-229.

257. Brigotti, M.; Rambelli, F.; Zamboni, M.; Montanaro, L.; Sperti, S. Effect of alpha-sarcin and ribosome-inactivating proteins on the interaction of elongation factors with ribosomes. Biochem. $J$. 1989, 257, 723-727.

258. Osborn, R.W.; Hartley, M.R. Dual effects of the ricin A chain on protein synthesis in rabbit reticulocyte lysate. Inhibition of initiation and translocation. Eur. J. Biochem. 1990, 193, 401-407.

259. Bergamaschi, G.; Perfetti, V.; Tonon, L.; Novella, A.; Lucotti, C.; Danova, M.; Glennie, M.J.; Merlini, G.; Cazzola, M. Saporin, a ribosome-inactivating protein used to prepare immunotoxins, induces cell death via apoptosis. Br. J. Haematol. 1996, 93, 789-794.

260. Bolognesi, A.; Tazzari, P.L.; Olivieri, F.; Polito, L.; Falini, B.; Stirpe, F. Induction of apoptosis by ribosome-inactivating proteins and related immunotoxins. Int. J. Canc. 1996, 68, 349-355.

261. Bantel, H.; Engels, I.H.; Voelter, W.; Schulze-Osthoff, K.; Wesselborg, S. Mistletoe lectin activates caspase-8/FLICE independently of death receptor signaling and enhances anticancer drug-induced apoptosis. Canc. Res. 1999, 59, 2083-2090.

262. Narayanan, S.; Surolia, A.; Karande, A.A. Ribosome-inactivating protein and apoptosis: Abrin causes cell death via mitochondrial pathway in Jurkat cells. Biochem. J. 2004, 377, 233-240.

263. Mi, S.L.; An, C.C.; Wang, Y.; Chen, J.Y.; Che, N.Y.; Gao, Y.; Chen, Z.L. Trichomislin, a novel ribosome-inactivating protein, induces apoptosis that involves mitochondria and caspase-3. Arch. Biochem. Biophys. 2005, 434, 258--265.

264. Rao, P.V.; Jayaraj, R.; Bhaskar, A.S.; Kumar, O.; Bhattacharya, R.; Saxena, P.; Dash, P.K.; Vijayaraghavan, R. Mechanism of ricin-induced apoptosis in human cervical cancer cells. Biochem. Pharmacol. 2005, 69, 855-865. 
265. Parikh, B.A.; Tumer, N.E. Antiviral activity of ribosome inactivating proteins in medicine. Mini Rev. Med. Chem. 2004, 4, 523-543.

266. Barbieri, L.; Valbonesi, P.; Bonora, E.; Gorini, P.; Bolognesi, A.; Stirpe, F. Polynucleotide: Adenosine glycosidase activity of ribosome-inactivating proteins: Effect on DNA, RNA and poly(A). Nucl. Acid. Res. 1997, 25, 518-522.

267. Barbieri, L.; Bolognesi, A.; Valbonesi, P.; Polito, L.; Olivieri, F.; Stirpe, F. Polynucleotide: Adenosine glycosidase activity of immunotoxins containing ribosome-inactivating proteins. J. Drug Target 2000, 8, 281-288.

268. Barbieri, L.; Valbonesi, P.; Govoni, M.; Pession, A.; Stirpe, F. Polynucleotide: Adenosine glycosidase activity of saporin-L1: Effect on various forms of mammalian DNA. Biochim. Biophys. Acta 2000, 1480, 258-266.

269. Barbieri, L.; Valbonesi, P.; Righi, F.; Zuccheri, G.; Monti, F.; Gorini, P.; Samori, B.; Stirpe, F. Polynucleotide: Adenosine glycosidase is the sole activity of ribosome-inactivating proteins on DNA. J. Biochem. 2000, 128, 883-889.

270. Nicolas, E.; Beggs, J.M.; Taraschi, T.F. Gelonin is an unusual DNA glycosylase that removes adenine from single-stranded DNA, normal base pairs and mismatches. J. Biol. Chem. 2000, 275, 31399-31406.

271. Li, M.X.; Yeung, H.W.; Pan, L.P.; Chan, S.I. Trichosanthin, a potent HIV-1 inhibitor, can cleave supercoiled DNA in vitro. Nucl. Acid. Res. 1991, 19, 6309-6312.

272. Ling, J.; Li, X.; Wu, X.; Liu, W. Topological requirements for recognition and cleavage of DNA by ribosome-inactivating proteins. Biol. Chem. Hoppe. Seyler 1995, 376, 637-641.

273. Roncuzzi, L.; Gasperi-Campani, A. DNA-nuclease activity of the single-chain ribosomeinactivating proteins dianthin 30, saporin 6 and gelonin. FEBS Lett. 1996, 392, 16-20.

274. Nicolas, E.; Beggs, J.M.; Haltiwanger, B.M.; Taraschi, T.F. Direct evidence for the deoxyribonuclease activity of the plant ribosome inactivating protein gelonin. FEBS Lett. 1997, 406, 162-164.

275. Wang, P.; Tumer, N.E. Pokeweed antiviral protein cleaves double-stranded supercoiled DNA using the same active site required to depurinate rRNA. Nucl. Acid. Res. 1999, 27, 1900-1905.

276. Bagga, S.; Seth, D.; Batra, J.K. The cytotoxic activity of ribosome-inactivating protein saporin-6 is attributed to its rRNA N-glycosidase and internucleosomal DNA fragmentation activities. J. Biol. Chem. 2003, 278, 4813-4820.

277. Gasperi-Campani, A.; Brognara, I.; Baiocchi, D.; Roncuzzi, L. Mitochondrial DNA D-loop as a new target of Saporin 6 nuclease activity. Toxicon 2005, 45, 475-480.

278. Choudhary, N.L.; Yadav, O.P.; Lodha, M.L. Ribonuclease, deoxyribonuclease, and antiviral activity of Escherichia coli-expressed Bougainvillea xbuttiana antiviral protein 1. Biochemistry (Mosc) 2008, 73, 273-277.

279. Mock, J.W.; Ng, T.B.; Wong, R.N.; Yao, Q.Z.; Yeung, H.W.; Fong, W.P. Demonstration of ribonuclease activity in the plant ribosome-inactivating proteins alpha- and beta-momorcharins. Life Sci. 1996, 59, 1853-1859.

280. Fong, W.P.; Mock, W.Y.; Ng, T.B. Intrinsic ribonuclease activities in ribonuclease and ribosome-inactivating proteins from the seeds of bitter gourd. Int. J. Biochem. Cell Biol. 2000, $32,571-577$. 
281. Herceg, Z.; Wang, Z.Q. Functions of poly(ADP-ribose) polymerase (PARP) in DNA repair, genomic integrity and cell death. Mutat. Res. 2001, 477, 97-110.

282. Barbieri, L.; Brigotti, M.; Perocco, P.; Carnicelli, D.; Ciani, M.; Mercatali, L.; Stirpe, F. Ribosome-inactivating proteins depurinate poly(ADP-ribosyl)ated poly(ADP-ribose) polymerase and have transforming activity for 3T3 fibroblasts. FEBS Lett. 2003, 538, 178-182.

283. Hudak, K.A.; Wang, P.; Tumer, N.E. A novel mechanism for inhibition of translation by pokeweed antiviral protein: Depurination of the capped RNA template. RNA 2000, 6, 369-380.

284. Vivanco, J.M.; Tumer, N.E. Translation Inhibition of Capped and Uncapped Viral RNAs Mediated by Ribosome-Inactivating Proteins. Phytopathology 2003, 93, 588-595.

285. Li, X.D.; Chen, W.F.; Liu, W.Y.; Wang, G.H. Large-scale preparation of two new ribosomeinactivating proteins - Cinnamomin and camphorin from the seeds of Cinnamomum camphora. Protein Expr. Purif. 1997, 10, 27-31.

286. Sharma, N.; Park, S.W.; Vepachedu, R.; Barbieri, L.; Ciani, M.; Stirpe, F.; Savary, B.J.; Vivanco, J.M. Isolation and characterization of an RIP (ribosome-inactivating protein)-like protein from tobacco with dual enzymatic activity. Plant Physiol. 2004, 134, 171-181.

287. Barbieri, L.; Polito, L.; Bolognesi, A.; Ciani, M.; Pelosi, E.; Farini, V.; Jha, A.K.; Sharma, N.; Vivanco, J.M.; Chambery, A.; Parente, A.; Stirpe, F. Ribosome-inactivating proteins in edible plants and purification and characterization of a new ribosome-inactivating protein from Cucurbita moschata. Biochim. Biophys. Acta 2006, 1760, 783-792.

288. Helmy, M.; Lombard, S.; Pieroni, G. Ricin RCA60: Evidence of its phospholipase activity. Biochem. Biophy.s Res. Commun. 1999, 258, 252-255.

289. Nicolas, E.; Goodyer, I.D.; Taraschi, T.F. An additional mechanism of ribosome-inactivating protein cytotoxicity: Degradation of extrachromosomal DNA. Biochem. J. 1997, 327, 413-417.

290. Brigotti, M.; Alfieri, R.; Sestili, P.; Bonelli, M.; Petronini, P.G.; Guidarelli, A.; Barbieri, L.; Stirpe, F.; Sperti, S. Damage to nuclear DNA induced by Shiga toxin 1 and ricin in human endothelial cells. FASEB J. 2002, 16, 365-372.

291. Sestili, P.; Alfieri, R.; Carnicelli, D.; Martinelli, C.; Barbieri, L.; Stirpe, F.; Bonelli, M.; Petronini, P.G.; Brigotti, M. Shiga toxin 1 and ricin inhibit the repair of H2O2-induced DNA single strand breaks in cultured mammalian cells. DNA Repair (Amst) 2005, 4, 271-277.

292. Brigotti, M.; Carnicelli, D.; Ravanelli, E.; Vara, A.G.; Martinelli, C.; Alfieri, R.R.; Petronini, P.G.; Sestili, P. Molecular damage and induction of proinflammatory cytokines in human endothelial cells exposed to Shiga toxin 1, Shiga toxin 2, and alpha-sarcin. Infect. Immun. 2007, 75, 2201-2207.

293. Li, X.P.; Baricevic, M.; Saidasan, H.; Tumer, N.E. Ribosome depurination is not sufficient for ricin-mediated cell death in Saccharomyces cerevisiae. Infect. Immun. 2007, 75, 417-428.

294. Sikriwal, D.; Ghosh, P.; Batra, J.K. Ribosome inactivating protein saporin induces apoptosis through mitochondrial cascade, independent of translation inhibition. Int. J. Biochem. Cell Biol. 2008, 40, 2880-2888.

295. Polito, L.; Bortolotti, M.; Farini, V.; Battelli, M.G.; Barbieri, L.; Bolognesi, A. Saporin induces multiple death pathways in lymphoma cells with different intensity and timing as compared to ricin. Int. J. Biochem. Cell Biol. 2009, 41, 1055-1061. 
296. Stein, H.; Mason, D.Y.; Gerdes, J.; O'Connor, N.; Wainscoat, J.; Pallesen, G.; Gatter, K.; Falini, B.; Delsol, G.; Lemke, H.; et al. The expression of the Hodgkin's disease associated antigen Ki-1 in reactive and neoplastic lymphoid tissue: Evidence that Reed-Sternberg cells and histiocytic malignancies are derived from activated lymphoid cells. Blood 1985, 66, 848-858.

297. Froese, P.; Lemke, H.; Gerdes, J.; Havsteen, B.; Schwarting, R.; Hansen, H.; Stein, H. Biochemical characterization and biosynthesis of the Ki-1 antigen in Hodgkin-derived and virustransformed human B and T lymphoid cell lines. J. Immunol. 1987, 139, 2081-2087.

298. Agnarsson, B.A.; Kadin, M.E. The immunophenotype of Reed-Sternberg cells. A study of 50 cases of Hodgkin's disease using fixed frozen tissues. Cancer 1989, 63, 2083-2087.

299. Foxwell, B.M.; Donovan, T.A.; Thorpe, P.E.; Wilson, G. The removal of carbohydrates from ricin with endoglycosidases H, F and D and alpha-mannosidase. Biochim. Biophys. Acta 1985, 840, 193-203.

300. Blakey, D.C.; Thorpe, P.E. Effect of chemical deglycosylation on the in vivo fate of ricin A-chain. Cancer Drug Deliv. 1986, 3, 189-196.

301. Bourrie, B.J.; Casellas, P.; Blythman, H.E.; Jansen, F.K. Study of the plasma clearance of antibody--ricin-A-chain immunotoxins. Evidence for specific recognition sites on the A chain that mediate rapid clearance of the immunotoxin. Eur. J. Biochem. 1986, 155, 1-10.

302. Skilleter, D.N.; Foxwell, B.M. Selective uptake of ricin A-chain by hepatic non-parenchymal cells in vitro. Importance of mannose oligosaccharides in the toxin. FEBS Lett. 1986, 196, 344-348.

303. Blakey, D.C.; Watson, G.J.; Knowles, P.P.; Thorpe, P.E. Effect of chemical deglycosylation of ricin A chain on the in vivo fate and cytotoxic activity of an immunotoxin composed of ricin $\mathrm{A}$ chain and anti-Thy 1.1 antibody. Canc. Res. 1987, 47, 947-952.

304. Fulton, R.J.; Tucker, T.F.; Vitetta, E.S.; Uhr, J.W. Pharmacokinetics of tumor-reactive immunotoxins in tumor-bearing mice: Effect of antibody valency and deglycosylation of the ricin A chain on clearance and tumor localization. Canc. Res. 1988, 48, 2618-2625.

305. Trown, P.W.; Reardan, D.T.; Carroll, S.F.; Stoudemire, J.B.; Kawahata, R.T. Improved pharmacokinetics and tumor localization of immunotoxins constructed with the $\mathrm{Mr} 30,000$ form of ricin A chain. Canc. Res. 1991, 51, 4219-4225.

306. Mason, D.Y.; Stein, H.; Gerdes, J.; Pulford, K.A.; Ralfkiaer, E.; Falini, B.; Erber, W.N.; Micklem, K.; Gatter, K.C. Value of monoclonal anti-CD22 (p135) antibodies for the detection of normal and neoplastic B lymphoid cells. Blood 1987, 69, 836-840.

307. Tedder, T.F.; Tuscano, J.; Sato, S.; Kehrl, J.H. CD22, a B lymphocyte-specific adhesion molecule that regulates antigen receptor signaling. Annu .Rev. Immunol. 1997, 15, 481-504.

308. Fujimoto, M.; Poe, J.C.; Inaoki, M.; Tedder, T.F. CD19 regulates B lymphocyte responses to transmembrane signals. Semin. Immunol. 1998, 10, 267-277.

309. Poe, J.C.; Hasegawa, M.; Tedder, T.F. CD19, CD21, and CD22: Multifaceted response regulators of B lymphocyte signal transduction. Int. Rev. Immunol. 2001, 20, 739-762.

310. Shen, G.L.; Li, J.L.; Ghetie, M.A.; Ghetie, V.; May, R.D.; Till, M.; Brown, A.N.; Relf, M.; Knowles, P.; Uhr, J.W.; et al. Evaluation of four CD22 antibodies as ricin A chain-containing immunotoxins for the in vivo therapy of human B-cell leukemias and lymphomas. Int. J. Canc. 1988, 42, 792-797. 
311. Pezzutto, A.; Dorken, B.; Rabinovitch, P.S.; Ledbetter, J.A.; Moldenhauer, G.; Clark, E.A. CD19 monoclonal antibody HD37 inhibits anti-immunoglobulin-induced B cell activation and proliferation. J. Immunol. 1987, 138, 2793-2799.

312. Amlot, P.L.; Stone, M.J.; Cunningham, D.; Fay, J.; Newman, J.; Collins, R.; May, R.; McCarthy, M.; Richardson, J.; Ghetie, V.; et al. A phase I study of an anti-CD22-deglycosylated ricin A chain immunotoxin in the treatment of B-cell lymphomas resistant to conventional therapy. Blood 1993, 82, 2624-2633.

313. Fathman, C.G.; Costa, G.L.; Seroogy, C.M. Gene therapy for autoimmune disease. Clin. Immunol. 2000, 95, S39-S43.

314. Kawashiri, M.-A.; Rader, D.J. Gene therapy for lipid disorders. Curr. Control Trials Cardiovasc. Med. 2000, 1, 120-127.

315. Kouraklis, G. Gene therapy for cancer: From the laboratory to the patient. Dig. Dis. Sci. 2000, $45,1045-1052$.

316. Lyngstadaas, A. Status and potential of gene therapy in clinical medicine. Assessment of an emerging health technology through systematic survey of clinical gene therapy protocols and published results. Int. J. Technol. Assess. Health. Care 2002, 18, 645-674.

317. Wadhwa, P.D.; Zielske, S.P.; Roth, J.C.; Ballas, C.B.; Bowman, J.E.; Gerson, S.L. Cancer gene therapy: Scientific basis. Annu. Rev. Med. 2002, 53, 437-452.

318. Dishart, K.L.; Work, L.M.; Denby, L.; Baker, A.H. Gene Therapy for Cardiovascular Disease. J. Biomed. Biotechnol. 2003, 2003, 138-148.

319. Selkirk, S.M. Gene therapy in clinical medicine. Postgrad. Med. J. 2004, 80, 560-570.

320. Cathomen, T.; Weitzman, M.D. Gene repair: Pointing the finger at genetic disease. Gene Ther. 2005, 12, 1415-1416.

321. Cross, D.; Burmester, J.K. Gene therapy for cancer treatment: Past, present and future. Clin. Med. Res. 2006, 4, 218-227.

322. Chuang, Y.H.; Yang, Y.H.; Wu, S.J.; Chiang, B.L. Gene therapy for allergic diseases. Curr. Gene Ther. 2009, 9, 185-191.

323. Cao, S.; Cripps, A.; Wei, M.Q. New strategies for cancer gene therapy: Progress and opportunities. Clin. Exp. Pharm. Physiol. 2010, 37, 108-114.

324. Itaka, K.; Kataoka, K. Recent development of nonviral gene delivery systems with virus-like structures and mechanisms. Eur. J. Pharm. Biopharm. 2009, 71, 475-483.

325. Pathak, A.; Patnaik, S.; Gupta, K.C. Recent trends in non-viral vector-mediated gene delivery. Biotechnol. J. 2009, 4, 1559-1572.

326. Heilbronn, R.; Weger, S. Viral vectors for gene transfer: Current status of gene therapeutics. Handbook Exp. Pharm. 2010, 197, 143-170.

327. Moolten, F.L. Drug sensitivity ("suicide") genes for selective cancer chemotherapy. Canc. Gene Ther. 1994, 1, 279-287.

328. Spencer, D.M. Developments in suicide genes for preclinical and clinical applications. Curr. Opin. Mol. Ther. 2000, 2, 433-440.

329. Ozawa, T.; Hu, J.L.; Hu, L.J.; Kong, E.L.; Bollen, A.W.; Lamborn, K.R.; Deen, D.F. Functionality of hypoxia-induced BAX expression in a human glioblastoma xenograft model. Canc. Gene Ther. 2005, 12, 449-455. 
330. Yang, W.S.; Park, S.O.; Yoon, A.R.; Yoo, J.Y.; Kim, M.K.; Yun, C.O.; Kim, C.W. Suicide cancer gene therapy using pore-forming toxin, streptolysin O. Mol. Canc. Ther. 2006, 5, 1610-1619.

331. Altaner, C. Prodrug cancer gene therapy. Canc. Lett 2008, 270, 191-201.

332. Maxwell, I.H.; Maxwell, F.O.; Glode, L.M. Regulated Expression of a Diphtheria Toxin A-Chain Gene Transfected into Human Cells: Possible Strategy for Inducing Cancer Cell Suicide. Canc. Res. 1986, 46, 4660-4664.

333. Walther, W.; Stein, U. Cell type specific and inducible promoters for vectors in gene therapy as an approach for cell targeting. J. Mol. Med. 1996, 74, 379-392.

334. Peng, K.W. Strategies for targeting therapeutic gene delivery. Mol. Med. Today 1999, 5, 448-453.

335. Nettelbeck, D.M.; Jerome, V.; Muller, R. Gene therapy: Designer promoters for tumour targeting. Trends Genet. 2000, 16, 174-181.

336. Haviv, Y.S.; Blackwell, J. Transcriptional regulation in cancer gene therapy. Isr. Med. Assoc. J. 2001, 3, 517-522.

337. Robson, T.; Hirst, D.G. Transcriptional Targeting in Cancer Gene Therapy. J. Biomed. Biotechnol. 2003, 2003, 110-137.

338. Dorer, D.E.; Nettelbeck, D.M. Targeting cancer by transcriptional control in cancer gene therapy and viral oncolysis. Adv .Drug. Deliv. Rev. 2009, 61, 554-571.

339. Li, Y.; McCadden, J.; Ferrer, F.; Kruszewski, M.; Carducci, M.; Simons, J.; Rodriguez, R. Prostate-specific expression of the diphtheria toxin A chain (DT-A): Studies of inducibility and specificity of expression of prostate-specific antigen promoter-driven DT-A adenoviral-mediated gene transfer. Canc. Res. 2002, 62, 2576-2582.

340. Peng, W.; Chen, J.; Huang, Y.H.; Sawicki, J.A. Tightly-regulated suicide gene expression kills PSA-expressing prostate tumor cells. Gene Ther. 2005, 12, 1573-1580.

341. Peng, W.; Anderson, D.G.; Bao, Y.; Padera, R.F., Jr.; Langer, R.; Sawicki, J.A. Nanoparticulate delivery of suicide DNA to murine prostate and prostate tumors. Prostate 2007, 67, 855-862.

342. Lidor, Y.J.; Lee, W.E.; Nilson, J.H.; Maxwell, I.H.; Su, L.J.; Brand, E.; Glode, L.M. In vitro expression of the diphtheria toxin A-chain gene under the control of human chorionic gonadotropin gene promoters as a means of directing toxicity to ovarian cancer cell lines. Am. J. Obstet. Gynecol. 1997, 177, 579-585.

343. Huang, Y.H.; Zugates, G.T.; Peng, W.; Holtz, D.; Dunton, C.; Green, J.J.; Hossain, N.; Chernick, M.R.; Padera, R.F., Jr.; Langer, R.; Anderson, D.G.; Sawicki, J.A. Nanoparticle-delivered suicide gene therapy effectively reduces ovarian tumor burden in mice. Canc. Res. 2009, 69, 6184-6191.

344. Sidi, A.A.; Ohana, P.; Benjamin, S.; Shalev, M.; Ransom, J.H.; Lamm, D.; Hochberg, A.; Leibovitch, I. Phase I/II marker lesion study of intravesical BC-819 DNA plasmid in H19 over expressing superficial bladder cancer refractory to bacillus Calmette-Guerin. J. Urol. 2008, 180, 2379-2383.

345. Mizrahi, A.; Czerniak, A.; Levy, T.; Amiur, S.; Gallula, J.; Matouk, I.; Abu-lail, R.; Sorin, V.; Birman, T.; de Groot, N.; Hochberg, A.; Ohana, P. Development of targeted therapy for ovarian cancer mediated by a plasmid expressing diphtheria toxin under the control of H19 regulatory sequences. J. Transl. Med. 2009, 7, 69. 
346. Mizrahi, A.; Czerniak, A.; Ohana, P.; Amiur, S.; Gallula, J.; Matouk, I.; Abu-Lail, R.; Birman, T.; Hochberg, A.; Levy, T. Treatment of ovarian cancer ascites by intra-peritoneal injection of diphtheria toxin A chain-H19 vector: A case report. J. Med. Case. Rep. 2010, 4, 228.

347. Abdul-Ghani, R.; Ohana, P.; Matouk, I.; Ayesh, S.; Ayesh, B.; Laster, M.; Bibi, O.; Giladi, H.; Molnar-Kimber, K.; Sughayer, M.A.; de Groot, N.; Hochberg, A. Use of Transcriptional Regulatory Sequences of Telomerase (hTER and hTERT) for Selective Killing of Cancer Cells. Mol. Ther. 2000, 2, 539-544.

348. Harrison, G.S.; Long, C.J.; Curiel, T.J.; Maxwell, F.; Maxwell, I.H. Inhibition of human immunodeficiency virus-1 production resulting from transduction with a retrovirus containing an HIV-regulated diphtheria toxin A chain gene. Hum. Gene. Ther. 1992, 3, 461-469.

349. Dinges, M.M.; Cook, D.R.; King, J.; Curiel, T.J.; Zhang, X.Q.; Harrison, G.S. HIV-regulated diphtheria toxin A chain gene confers long-term protection against HIV type 1 infection in the human promonocytic cell line U937. Hum. Gene. Ther. 1995, 6, 1437-1445.

350. Konopka, K.; Harrison, G.S.; Felgner, P.L.; Duzgunes, N. Cationic liposome-mediated expression of HIV-regulated luciferase and diphtheria toxin a genes in HeLa cells infected with or expressing HIV. Biochim. Biophys. Acta 1997, 1356, 185-197.

351. Wang, Z.; Tang, Z.; Zheng, Y.; Yu, D.; Spear, M.; Iyer, S.R.; Bishop, B.; Wu, Y. Development of a nonintegrating Rev-dependent lentiviral vector carrying diphtheria toxin A chain and human TRAF6 to target HIV reservoirs. Gene Ther. 2010, 17, 1063-1076.

352. Massuda, E.S.; Dunphy, E.J.; Redman, R.A.; Schreiber, J.J.; Nauta, L.E.; Barr, F.G.; Maxwell, I.H.; Cripe, T.P. Regulated expression of the diphtheria toxin A chain by a tumor-specific chimeric transcription factor results in selective toxicity for alveolar rhabdomyosarcoma cells. Proc. Natl. Acad. Sci. USA 1997, 94, 14701-14706.

353. Maxwell, I.H.; Kaletta, C.; Naujoks, K.; Maxwell, F. Targeting diphtheria toxin A-chain transcription to activated endothelial cells using an E-selectin promoter. Angiogenesis 2003, 6, 31-38.

354. Lee, E.J.; Jameson, J.L. Cell-specific Cre-mediated activation of the diphtheria toxin gene in pituitary tumor cells: Potential for cytotoxic gene therapy. Hum. Gene Ther. 2002, 13, 533-542.

355. Wang, C.Y.; Li, F.; Yang, Y.; Guo, H.Y.; Wu, C.X.; Wang, S. Recombinant baculovirus containing the diphtheria toxin A gene for malignant glioma therapy. Canc. Res. 2006, 66, 5798-5806.

356. Cao, G.W.; Qi, Z.T.; Pan, X.; Zhang, X.Q.; Miao, X.H.; Feng, Y.; Lu, X.H.; Kuriyama, S.; Du, P. Gene therapy for human colorectal carcinoma using human CEA promoter contro led bacterial ADP-ribosylating toxin genes human CEA: PEA \& DTA gene transfer. World J. Gastroenterol. 1998, 4, 388-391.

357. Hine, C.M.; Seluanov, A.; Gorbunova, V. Use of the Rad51 promoter for targeted anti-cancer therapy. Proc .Natl. Acad. Sci. USA 2008, 105, 20810-20815.

358. Murayama, Y.; Tadakuma, T.; Kunitomi, M.; Kumai, K.; Tsutsui, K.; Yasuda, T.; Kitajima, M. Cell-specific expression of the diphtheria toxin A-chain coding sequence under the control of the upstream region of the human alpha-fetoprotein gene. J. Surg. Oncol. 1999, 70, 145-149. 
359. Kunitomi, M.; Takayama, E.; Suzuki, S.; Yasuda, T.; Tsutsui, K.; Nagaike, K.; Hiroi, S.; Tadakuma, T. Selective inhibition of hepatoma cells using diphtheria toxin A under the control of the promoter/enhancer region of the human alpha-fetoprotein gene. Jpn. J. Canc. Res. 2000, 91, 343-350.

360. Maxwell, I.H.; Glode, L.M.; Maxwell, F. Expression of the diphtheria toxin A-chain coding sequence under the control of promoters and enhancers from immunoglobulin genes as a means of directing toxicity to B-lymphoid cells. Canc. Res. 1991, 51, 4299-4304.

361. Rothfels, H.; Paschen, A.; Schadendorf, D. Evaluation of combined gene regulatory elements for transcriptional targeting of suicide gene expression to malignant melanoma. Exp. Dermatol. 2003, 12, 799-810.

362. Martin, V.; Cortes, M.L.; de Felipe, P.; Farsetti, A.; Calcaterra, N.B.; Izquierdo, M. Cancer gene therapy by thyroid hormone-mediated expression of toxin genes. Canc. Res. 2000, 60, 3218-3224.

363. Showalter, S.L.; Huang, Y.H.; Witkiewicz, A.; Costantino, C.L.; Yeo, C.J.; Green, J.J.; Langer, R.; Anderson, D.G.; Sawicki, J.A.; Brody, J.R. Nanoparticulate delivery of diphtheria toxin DNA effectively kills Mesothelin expressing pancreatic cancer cells. Canc. Biol. Ther. 2008, 7, $1584-1590$.

364. Fogar, P.; Navaglia, F.; Basso, D.; Zambon, C.F.; Moserle, L.; Indraccolo, S.; Stranges, A.; Greco, E.; Fadi, E.; Padoan, A.; Pantano, G.; Sanzari, M.C.; Pedrazzoli, S.; Montecucco, C.; Plebani, M. Heat-induced transcription of diphtheria toxin A or its variants, CRM176 and CRM197: Implications for pancreatic cancer gene therapy. Canc. Gene Ther. 2010, 17, 58-68.

365. Lee, J.T.; Watarai, S.; Kakidani, H.; Onuma, M.; Zhao, D.D.; Yasuda, T. Evaluation of cationic liposomes for delivery of diphtheria toxin A-chain gene to cells infected with bovine leukemia virus. J. Vet. Med. Sci. 1997, 59, 169-174.

366. Tana; Watarai, S.; Lee, J.T.; Onuma, M.; Ochiai, K.; Kakidani, H.; Yasuda, T. In vivo antitumor effect of cationic liposomes containing diphtheria toxin A-chain gene on cells infected with bovine leukemia virus. J.Vet. Med. Sci. 1997, 59, 617-619.

367. Diaw, L.; Woodson, K.; Gillespie, J.W. Prostate cancer epigenetics: A review on gene regulation. Gene Regul. Syst. Bio. 2007, 1, 313-325.

368. Lilja, H. A kallikrein-like serine protease in prostatic fluid cleaves the predominant seminal vesicle protein. J. Clin. Invest. 1985, 76, 1899-1903.

369. Lilja, H. Structure, function, and regulation of the enzyme activity of prostate-specific antigen. World J. Urol. 1993, 11, 188-191.

370. Aumuller, G.; Seitz, J.; Lilja, H.; Abrahamsson, P.A.; von der Kammer, H.; Scheit, K.H. Speciesand organ-specificity of secretory proteins derived from human prostate and seminal vesicles. Prostate 1990, 17, 31-40.

371. Wu, L.; Matherly, J.; Smallwood, A.; Adams, J.Y.; Billick, E.; Belldegrun, A.; Carey, M. Chimeric PSA enhancers exhibit augmented activity in prostate cancer gene therapy vectors. Gene Ther. 2001, 8, 1416-1426.

372. Mabjeesh, N.J.; Zhong, H.; Simons, J.W. Gene therapy of prostate cancer: Current and future directions. Endocr. Relat. Canc. 2002, 9, 115-139. 
373. Makarov, D.V.; Loeb, S.; Getzenberg, R.H.; Partin, A.W. Biomarkers for prostate cancer. Annu. Rev. Med. 2009, 60, 139-151.

374. Zheng, J.Y.; Chen, D.; Chan, J.; Yu, D.; Ko, E.; Pang, S. Regression of prostate cancer xenografts by a lentiviral vector specifically expressing diphtheria toxin A. Canc. Gene Ther. 2003, 10, 764-770.

375. Anderson, D.G.; Peng, W.; Akinc, A.; Hossain, N.; Kohn, A.; Padera, R.; Langer, R.; Sawicki, J.A. A polymer library approach to suicide gene therapy for cancer. Proc. Natl. Acad. Sci. USA 2004, 101, 16028-16033.

376. Picard, D. Regulation of protein function through expression of chimaeric proteins. Curr. Opin. Biotechnol. 1994, 5, 511-515.

377. Logie, C.; Stewart, A.F. Ligand-regulated site-specific recombination. Proc. Natl. Acad. Sci USA 1995, 92, 5940-5944.

378. Peng, W.; Verbitsky, A.; Bao, Y.; Sawicki, J. Regulated expression of diphtheria toxin in prostate cancer cells. Mol. Ther. 2002, 6, 537-545.

379. Cho, K.R.; Shih Ie, M. Ovarian cancer. Annu Rev Pathol 2009, 4, 287-313.

380. Tsampalas, M.; Gridelet, V.; Berndt, S.; Foidart, J.M.; Geenen, V.; Perrier d'Hauterive, S. Human chorionic gonadotropin: A hormone with immunological and angiogenic properties. J. Reprod. Immunol. 2010, 85, 93-98.

381. Eagle, K.; Ledermann, J.A. Tumor Markers in Ovarian Malignancies. The Oncologist 1997, 2, 324-329.

382. Demirtas, E.; Krishnamurthy, S.; Tulandi, T. Elevated serum beta-human chorionic gonadotropin In nonpregnant conditions. Obstet. Gynecol. Surv. 2007, 62, 675-679.

383. Scholler, N.; Fu, N.; Yang, Y.; Ye, Z.; Goodman, G.E.; Hellstrom, K.E.; Hellstrom, I. Soluble member(s) of the mesothelin/megakaryocyte potentiating factor family are detectable in sera from patients with ovarian carcinoma. Proc. Natl. Acad. Sci. USA 1999, 96, 11531-11536.

384. Schummer, M.; Ng, W.V.; Bumgarner, R.E.; Nelson, P.S.; Schummer, B.; Bednarski, D.W.; Hassell, L.; Baldwin, R.L.; Karlan, B.Y.; Hood, L. Comparative hybridization of an array of 21 500 ovarian cDNAs for the discovery of genes overexpressed in ovarian carcinomas. Gene 1999, 238, 375-385.

385. Wang, K.; Gan, L.; Jeffery, E.; Gayle, M.; Gown, A.M.; Skelly, M.; Nelson, P.S.; Ng, W.V.; Schummer, M.; Hood, L.; Mulligan, J. Monitoring gene expression profile changes in ovarian carcinomas using cDNA microarray. Gene 1999, 229, 101-108.

386. Hough, C.D.; Sherman-Baust, C.A.; Pizer, E.S.; Montz, F.J.; Im, D.D.; Rosenshein, N.B.; Cho, K.R.; Riggins, G.J.; Morin, P.J. Large-scale serial analysis of gene expression reveals genes differentially expressed in ovarian cancer. Canc. Res. 2000, 60, 6281-6287.

387. Frierson, H.F., Jr.; Moskaluk, C.A.; Powell, S.M.; Zhang, H.; Cerilli, L.A.; Stoler, M.H.; Cathro, H.; Hampton, G.M. Large-scale molecular and tissue microarray analysis of mesothelin expression in common human carcinomas. Hum. Pathol. 2003, 34, 605-609.

388. Ordonez, N.G. Application of mesothelin immunostaining in tumor diagnosis. Am. J. Surg. Pathol. 2003, 27, 1418-1428.

389. Li, J.; Dowdy, S.; Tipton, T.; Podratz, K.; Lu, W.G.; Xie, X.; Jiang, S.W. HE4 as a biomarker for ovarian and endometrial cancer management. Expert Rev. Mol. Diagn. 2009, 9, 555-566. 
390. Tanos, V.; Prus, D.; Ayesh, S.; Weinstein, D.; Tykocinski, M.L.; De-Groot, N.; Hochberg, A.; Ariel, I. Expression of the imprinted H19 oncofetal RNA in epithelial ovarian cancer. Eur. J. Obstet. Gynecol. Reprod. Biol. 1999, 85, 7-11.

391. Steenman, M.J.; Rainier, S.; Dobry, C.J.; Grundy, P.; Horon, I.L.; Feinberg, A.P. Loss of imprinting of IGF2 is linked to reduced expression and abnormal methylation of H19 in Wilms' tumour. Nat. Genet. 1994, 7, 433-439.

392. Ilana, A.; Orit, L.; Tamar, S.; Galina, P.; Mally, S.; Nathan, D.-G.; Abraham, H. The imprinted H19 gene as a tumor marker in bladder carcinoma. Urology 1995, 45, 335-338.

393. Kondo, M.; Suzuki, H.; Ueda, R.; Osada, H.; Takagi, K.; Takahashi, T. Frequent loss of imprinting of the $\mathrm{H} 19$ gene is often associated with its overexpression in human lung cancers. Oncogene 1995, 10, 1193-1198.

394. Douc-Rasy, S.; Barrois, M.; Fogel, S.; Ahomadegbe, J.C.; Stehelin, D.; Coll, J.; Riou, G. High incidence of loss of heterozygosity and abnormal imprinting of H19 and IGF2 genes in invasive cervical carcinomas. Uncoupling of H19 and IGF2 expression and biallelic hypomethylation of H19. Oncogene 1996, 12, 423-430.

395. Hibi, K.; Nakamura, H.; Hirai, A.; Fujikake, Y.; Kasai, Y.; Akiyama, S.; Ito, K.; Takagi, H. Loss of H19 imprinting in esophageal cancer. Canc. Res. 1996, 56, 480-482.

396. Ariel, I.; Ayesh, S.; Perlman, E.J.; Pizov, G.; Tanos, V.; Schneider, T.; Erdmann, V.A.; Podeh, D.; Komitowski, D.; Quasem, A.S.; de Groot, N.; Hochberg, A. The product of the imprinted H19 gene is an oncofetal RNA. Mol. Pathol. 1997, 50, 34-44.

397. Ariel, I.; Miao, H.Q.; Ji, X.R.; Schneider, T.; Roll, D.; de Groot, N.; Hochberg, A.; Ayesh, S. Imprinted H19 oncofetal RNA is a candidate tumour marker for hepatocellular carcinoma. Mol. Pathol. 1998, 51, 21-25.

398. Jirtle, R.L. Genomic imprinting and cancer. Exp. Cell. Res. 1999, 248, 18-24.

399. Erdmann, V.A.; Barciszewska, M.Z.; Szymanski, M.; Hochberg, A.; Groot, N.d.; Barciszewski, J. The non-coding RNAs as riboregulators. Nucl. Acid. Res. 2001, 29, 189-193.

400. Pow-Sang, J.M.; Seigne, J.D. Contemporary management of superficial bladder cancer. Canc. Control 2000, 7, 335-339.

401. Jacobs, B.L.; Lee, C.T.; Montie, J.E. Bladder cancer in 2010: How far have we come? CA Canc. J. Clin. 2010, 60, 244-272.

402. Shay, J.W.; Zou, Y.; Hiyama, E.; Wright, W.E. Telomerase and cancer. Hum. Mol. Genet. 2001, 10, 677-685.

403. Blackburn, E.H. Switching and Signaling at the Telomere. Cell 2001, 106, 661-673.

404. Mark, J.C.; Martin, F.; Dymitr, K.; Alexander, S.; Ekkehard, S.; Ilana, A.; Mark, L.T.; Stela, M.; Joseph, I.; Nathan De, G.; Abraham, H. Developmentally Imprinted Genes as Markers for Bladder Tumor Progression. J. Urol. 1996, 155, 2120-2127.

405. Ohana, P.; Bibi, O.; Matouk, I.; Levy, C.; Birman, T.; Ariel, I.; Schneider, T.; Ayesh, S.; Giladi, H.; Laster, M.; Groot, N.d.; Hochberg, A. Use of H19 regulatory sequences for targeted gene therapy in cancer. Int. J. Canc. 2002, 98, 645-650.

406. Ohana, P.; Gofrit, O.; Ayesh, S.; Al-Sharef, W.; Mizrahi, A.; Birman, T.; Schneider, T.; Matouk, I.; Groot, N.d.; Tavdy, E.; Sidi, A.A.; Hochberg, A. Regulatory sequences of the H19 gene in DNA based therapy of bladder cancer. Gene Ther. Mol. Biol. 2004, 8, 181-192. 
407. Freed, E.O. HIV-1 replication. Somat. Cell. Mol. Genet. 2001, 26, 13-33.

408. Liang, C.; Wainberg, M.A. The role of Tat in HIV-1 replication: An activator and/or a suppressor? AIDS Rev. 2002, 4, 41-49.

409. Wu, Y.; Marsh, J.W. Gene transcription in HIV infection. Microb. Infect. 2003, 5, 1023-1027.

410. Pugliese, A.; Vidotto, V.; Beltramo, T.; Petrini, S.; Torre, D. A review of HIV-1 Tat protein biological effects. Cell Biochem. Funct. 2005, 23, 223-227.

411. Suhasini, M.; Reddy, T.R. Cellular proteins and HIV-1 Rev function. Curr. HIV Res. 2009, 7, 91-100.

412. Fanales-Belasio, E.; Raimondo, M.; Suligoi, B.; Butto, S. HIV virology and pathogenetic mechanisms of infection: A brief overview. Ann. Ist. Super. Sanita 2010, 46, 5-14.

413. Harrison, G.S.; Maxwell, F.; Long, C.J.; Rosen, C.A.; Glode, L.M.; Maxwell, I.H. Activation of a diphtheria toxin A gene by expression of human immunodeficiency virus-1 Tat and Rev proteins in transfected cells. Hum. Gene. Ther. 1991, 2, 53-60.

414. Harrison, G.S.; Long, C.J.; Maxwell, F.; Glode, L.M.; Maxwell, I.H. Inhibition of HIV production in cells containing an integrated, HIV-regulated diphtheria toxin A chain gene. AIDS Res. Hum. Retroviruses 1992, 8, 39-45.

415. Curiel, T.J.; Cook, D.R.; Wang, Y.; Hahn, B.H.; Ghosh, S.K.; Harrison, G.S. Long-term inhibition of clinical and laboratory human immunodeficiency virus strains in human T-cell lines containing an HIV-regulated diphtheria toxin A chain gene. Hum. Gene Ther. 1993, 4, 741-747.

416. Kedzierska, K.; Crowe, S.M. The role of monocytes and macrophages in the pathogenesis of HIV-1 infection. Curr. Med. Chem. 2002, 9, 1893-1903.

417. Williams, D.P.; Wen, Z.; Watson, R.S.; Boyd, J.; Strom, T.B.; Murphy, J.R. Cellular processing of the interleukin-2 fusion toxin DAB486-IL-2 and efficient delivery of diphtheria fragment A to the cytosol of target cells requires Arg194. J. Biol. Chem. 1990, 265, 20673-20677.

418. Klimpel, K.R.; Molloy, S.S.; Thomas, G.; Leppla, S.H. Anthrax toxin protective antigen is activated by a cell surface protease with the sequence specificity and catalytic properties of furin. Proc. Natl. Acad .Sci. USA 1992, 89, 10277-10281.

419. Gordon, V.M.; Leppla, S.H. Proteolytic activation of bacterial toxins: Role of bacterial and host cell proteases. Infect. Immun. 1994, 62, 333-340.

420. Beauregard, K.E.; Collier, R.J.; Swanson, J.A. Proteolytic activation of receptor-bound anthrax protective antigen on macrophages promotes its internalization. Cell. Microbiol. 2000, 2, 251-258.

421. Liu, S.; Netzel-Arnett, S.; Birkedal-Hansen, H.; Leppla, S.H. Tumor cell-selective cytotoxicity of matrix metalloproteinase-activated anthrax toxin. Canc. Res. 2000, 60, 6061-6067.

422. Liu, S.; Wang, H.; Currie, B.M.; Molinolo, A.; Leung, H.J.; Moayeri, M.; Basile, J.R.; Alfano, R.W.; Gutkind, J.S.; Frankel, A.E.; Bugge, T.H.; Leppla, S.H. Matrix metalloproteinaseactivated anthrax lethal toxin demonstrates high potency in targeting tumor vasculature. J. Biol. Chem. 2008, 283, 529-540.

423. Alfano, R.W.; Leppla, S.H.; Liu, S.; Bugge, T.H.; Meininger, C.J.; Lairmore, T.C.; Mulne, A.F.; Davis, S.H.; Duesbery, N.S.; Frankel, A.E. Matrix metalloproteinase-activated anthrax lethal toxin inhibits endothelial invasion and neovasculature formation during in vitro morphogenesis. Mol. Canc. Res. 2009, 7, 452-461. 
424. Alfano, R.W.; Leppla, S.H.; Liu, S.; Bugge, T.H.; Ortiz, J.M.; Lairmore, T.C.; Duesbery, N.S.; Mitchell, I.C.; Nwariaku, F.; Frankel, A.E. Inhibition of tumor angiogenesis by the matrix metalloproteinase-activated anthrax lethal toxin in an orthotopic model of anaplastic thyroid carcinoma. Mol. Canc. Ther. 2010, 9, 190-201.

425. Liu, S.; Bugge, T.H.; Leppla, S.H. Targeting of tumor cells by cell surface urokinase plasminogen activator-dependent anthrax toxin. J. Biol. Chem. 2001, 276, 17976-17984.

426. Liu, S.; Aaronson, H.; Mitola, D.J.; Leppla, S.H.; Bugge, T.H. Potent antitumor activity of a urokinase-activated engineered anthrax toxin. Proc. Natl. Acad. Sci. USA 2003, 100, 657-662.

427. Abi-Habib, R.J.; Singh, R.; Liu, S.; Bugge, T.H.; Leppla, S.H.; Frankel, A.E. A urokinaseactivated recombinant anthrax toxin is selectively cytotoxic to many human tumor cell types. Mol. Canc. Ther. 2006, 5, 2556-2562.

428. Rono, B.; Romer, J.; Liu, S.; Bugge, T.H.; Leppla, S.H.; Kristjansen, P.E. Antitumor efficacy of a urokinase activation-dependent anthrax toxin. Mol. Canc. Ther. 2006, 5, 89-96.

429. Su, Y.; Ortiz, J.; Liu, S.; Bugge, T.H.; Singh, R.; Leppla, S.H.; Frankel, A.E. Systematic urokinase-activated anthrax toxin therapy produces regressions of subcutaneous human non-small cell lung tumor in athymic nude mice. Canc. Res. 2007, 67, 3329-3336.

430. Liu, S.; Redeye, V.; Kuremsky, J.G.; Kuhnen, M.; Molinolo, A.; Bugge, T.H.; Leppla, S.H. Intermolecular complementation achieves high-specificity tumor targeting by anthrax toxin. Nat. Biotechnol. 2005, 23, 725-730.

431. Tcherniuk, S.O.; Chroboczek, J.; Balakirev, M.Y. Construction of tumor-specific toxins using ubiquitin fusion technique. Mol. Ther. 2005, 11, 196-204.

432. Abi-Habib, R.J.; Liu, S.; Bugge, T.H.; Leppla, S.H.; Frankel, A.E. A urokinase-activated recombinant diphtheria toxin targeting the granulocyte-macrophage colony-stimulating factor receptor is selectively cytotoxic to human acute myeloid leukemia blasts. Blood 2004, 104, 2143-2148.

433. Falnes, P.O.; Welker, R.; Krausslich, H.G.; Olsnes, S. Toxins that are activated by HIV type-1 protease through removal of a signal for degradation by the N-end-rule pathway. Biochem. J. 1999, 343, 199-207.

434. Law, S.K.; Wang, R.R.; Mak, A.N.; Wong, K.B.; Zheng, Y.T.; Shaw, P.C. A switch-on mechanism to activate maize ribosome-inactivating protein for targeting HIV-infected cells. Nucl. Acid. Res. 2010, doi: 10.1093/nar/gkq551.

435. Westermarck, J.; Kahari, V.-M. Regulation of matrix metalloproteinase expression in tumor invasion. FASEB J. 1999, 13, 781-792.

436. Stamenkovic, I. Matrix metalloproteinases in tumor invasion and metastasis. Semin. Canc. Biol. 2000, 10, 415-433.

437. Konjević, G.; Stanković, S. - Matrix metalloproteinases in the process of invasion and metastasis of breast cancer. Arch. Oncol. 2006, 14, 136-140.

438. Fingleton, B. Matrix metalloproteinases as valid clinical targets. Curr. Pharm. Des. 2007, 13, 333-346.

439. Roy, R.; Yang, J.; Moses, M.A. Matrix Metalloproteinases As Novel Biomarkers and Potential Therapeutic Targets in Human Cancer. J. Clin. Oncol. 2009, 27, 5287-5297. 
440. Ascenzi, P.; Visca, P.; Ippolito, G.; Spallarossa, A.; Bolognesi, M.; Montecucco, C. Anthrax toxin: A tripartite lethal combination. FEBS Lett. 2002, 531, 384-388.

441. Collier, R.J.; Young, J.A. Anthrax toxin. Annu. Rev. Cell Dev. Biol. 2003, 19, 45-70.

442. Young, J.A.; Collier, R.J. Anthrax toxin: Receptor binding, internalization, pore formation, and translocation. Annu. Rev. Biochem. 2007, 76, 243-265.

443. Bradley, K.A.; Mogridge, J.; Mourez, M.; Collier, R.J.; Young, J.A. Identification of the cellular receptor for anthrax toxin. Nature 2001, 414, 225-229.

444. Scobie, H.M.; Rainey, G.J.; Bradley, K.A.; Young, J.A. Human capillary morphogenesis protein 2 functions as an anthrax toxin receptor. Proc. Natl. Acad. Sci. USA 2003, 100, 5170-5174.

445. Milne, J.C.; Furlong, D.; Hanna, P.C.; Wall, J.S.; Collier, R.J. Anthrax protective antigen forms oligomers during intoxication of mammalian cells. J. Biol. Chem. 1994, 269, 20607-20612.

446. Abrami, L.; Liu, S.; Cosson, P.; Leppla, S.H.; van der Goot, F.G. Anthrax toxin triggers endocytosis of its receptor via a lipid raft-mediated clathrin-dependent process. J. Cell. Biol. 2003, 160, 321-328.

447. Abrami, L.; Bischofberger, M.; Kunz, B.; Groux, R.; Van der Goot, F. Endocytosis of the Anthrax Toxin Is Mediated by Clathrin, Actin and Unconventional Adaptors. PLoS Pathog. 2010, 6, e1000792.

448. Abrami, L.; Lindsay, M.; Parton, R.G.; Leppla, S.H.; van der Goot, F.G. Membrane insertion of anthrax protective antigen and cytoplasmic delivery of lethal factor occur at different stages of the endocytic pathway. J. Cell. Biol. 2004, 166, 645-651.

449. Blaustein, R.O.; Koehler, T.M.; Collier, R.J.; Finkelstein, A. Anthrax toxin: Channel-forming activity of protective antigen in planar phospholipid bilayers. Proc. Natl. Acad. Sci. USA 1989, 86, 2209-2213.

450. Milne, J.C.; Collier, R.J. pH-dependent permeabilization of the plasma membrane of mammalian cells by anthrax protective antigen. Mol. Microbiol. 1993, 10, 647-653.

451. Finkelstein, A. The channel formed in planar lipid bilayers by the protective antigen component of anthrax toxin. Toxicology 1994, 87, 29-41.

452. Krantz, B.A.; Melnyk, R.A.; Zhang, S.; Juris, S.J.; Lacy, D.B.; Wu, Z.; Finkelstein, A.; Collier, R.J. A phenylalanine clamp catalyzes protein translocation through the anthrax toxin pore. Science 2005, 309, 777-781.

453. Krantz, B.A.; Finkelstein, A.; Collier, R.J. Protein Translocation through the Anthrax Toxin Transmembrane Pore is Driven by a Proton Gradient. J. Mol. Biol. 2006, 355, 968-979.

454. Tamayo, A.G.; Bharti, A.; Trujillo, C.; Harrison, R.; Murphy, J.R. COPI coatomer complex proteins facilitate the translocation of anthrax lethal factor across vesicular membranes in vitro. Proc. Natl. Acad .Sci. USA 2008, 105, 5254-5259.

455. Collier, R.J. Membrane translocation by anthrax toxin. Mol. Aspects Med. 2009, 30, 413-422.

456. Finkelstein, A. Proton-coupled protein transport through the anthrax toxin channel. Philos. Trans. R. Soc. Lond. B. Biol. Sci. 2009, 364, 209-215.

457. Van der Goot, G.; Young, J.A. Receptors of anthrax toxin and cell entry. Mol. Aspects Med. 2009, 30, 406-412. 
458. Duesbery, N.S.; Webb, C.P.; Leppla, S.H.; Gordon, V.M.; Klimpel, K.R.; Copeland, T.D.; Ahn, N.G.; Oskarsson, M.K.; Fukasawa, K.; Paull, K.D.; Vande Woude, G.F. Proteolytic inactivation of MAP-kinase-kinase by anthrax lethal factor. Science 1998, 280, 734-737.

459. Duesbery, N.S.; Vande Woude, G.F. Anthrax lethal factor causes proteolytic inactivation of mitogen-activated protein kinase kinase. J. Appl. Microbiol. 1999, 87, 289-293.

460. Pellizzari, R.; Guidi-Rontani, C.; Vitale, G.; Mock, M.; Montecucco, C. Anthrax lethal factor cleaves MKK3 in macrophages and inhibits the LPS/IFNgamma-induced release of NO and TNFalpha. FEBS Lett. 1999, 462, 199-204.

461. Vitale, G.; Pellizzari, R.; Recchi, C.; Napolitani, G.; Mock, M.; Montecucco, C. Anthrax lethal factor cleaves the N-terminus of MAPKKS and induces tyrosine/threonine phosphorylation of MAPKS in cultured macrophages. J. Appl. Microbiol. 1999, 87, 288.

462. Vitale, G.; Bernardi, L.; Napolitani, G.; Mock, M.; Montecucco, C. Susceptibility of mitogenactivated protein kinase kinase family members to proteolysis by anthrax lethal factor. Biochem. J. 2000, 352, 739-745.

463. Park, J.M.; Greten, F.R.; Li, Z.W.; Karin, M. Macrophage apoptosis by anthrax lethal factor through p38 MAP kinase inhibition. Science 2002, 297, 2048-2051.

464. Agrawal, A.; Lingappa, J.; Leppla, S.H.; Agrawal, S.; Jabbar, A.; Quinn, C.; Pulendran, B. Impairment of dendritic cells and adaptive immunity by anthrax lethal toxin. Nature 2003, 424, 329-334.

465. Chopra, A.P.; Boone, S.A.; Liang, X.; Duesbery, N.S. Anthrax lethal factor proteolysis and inactivation of MAPK kinase. J. Biol. Chem. 2003, 278, 9402-9406.

466. Tonello, F.; Montecucco, C. The anthrax lethal factor and its MAPK kinase-specific metalloprotease activity. Mol. Aspects Med. 2009, 30, 431-438.

467. Leppla, S.H. Anthrax toxin edema factor: A bacterial adenylate cyclase that increases cyclic AMP concentrations of eukaryotic cells. Proc. Natl. Acad. Sci. USA 1982, 79, 3162-3166.

468. Leppla, S.H. Bacillus anthracis calmodulin-dependent adenylate cyclase: Chemical and enzymatic properties and interactions with eucaryotic cells. Adv. Cyclic Nucl. Protein Phosph. Res. 1984, 17, 189-198.

469. Drum, C.L.; Yan, S.Z.; Sarac, R.; Mabuchi, Y.; Beckingham, K.; Bohm, A.; Grabarek, Z.; Tang, W.J. An extended conformation of calmodulin induces interactions between the structural domains of adenylyl cyclase from Bacillus anthracis to promote catalysis. J. Biol. Chem. 2000, 275, 36334-36340.

470. Drum, C.L.; Yan, S.Z.; Bard, J.; Shen, Y.Q.; Lu, D.; Soelaiman, S.; Grabarek, Z.; Bohm, A.; Tang, W.J. Structural basis for the activation of anthrax adenylyl cyclase exotoxin by calmodulin. Nature 2002, 415, 396-402.

471. Ulmer, T.S.; Soelaiman, S.; Li, S.; Klee, C.B.; Tang, W.J.; Bax, A. Calcium dependence of the interaction between calmodulin and anthrax edema factor. J. Biol. Chem. 2003, 278, 29261-29266.

472. Shen, Y.; Zhukovskaya, N.L.; Guo, Q.; Florian, J.; Tang, W.J. Calcium-independent calmodulin binding and two-metal-ion catalytic mechanism of anthrax edema factor. EMBO J. 2005, 24, 929-941. 
473. Di Nezza, L.A.; Misajon, A.; Zhang, J.; Jobling, T.; Quinn, M.A.; Ostor, A.G.; Nie, G.; Lopata, A.; Salamonsen, L.A. Presence of active gelatinases in endometrial carcinoma and correlation of matrix metalloproteinase expression with increasing tumor grade and invasion. Cancer 2002, 94 , $1466-1475$.

474. Sato, T.; Sakai, T.; Noguchi, Y.; Takita, M.; Hirakawa, S.; Ito, A. Tumor-stromal cell contact promotes invasion of human uterine cervical carcinoma cells by augmenting the expression and activation of stromal matrix metalloproteinases. Gynecol. Oncol. 2004, 92, 47-56.

475. Berube, M.; Deschambeault, A.; Boucher, M.; Germain, L.; Petitclerc, E.; Guerin, S.L. MMP-2 expression in uveal melanoma: Differential activation status dictated by the cellular environment. Mol. Vis. 2005, 11, 1101-1111.

476. Roomi, M.W.; Monterrey, J.C.; Kalinovsky, T.; Rath, M.; Niedzwiecki, A. Patterns of MMP-2 and MMP-9 expression in human cancer cell lines. Oncol. Rep. 2009, 21, 1323-1333.

477. Arora, N.; Klimpel, K.R.; Singh, Y.; Leppla, S.H. Fusions of anthrax toxin lethal factor to the ADP-ribosylation domain of Pseudomonas exotoxin A are potent cytotoxins which are translocated to the cytosol of mammalian cells. J. Biol. Chem. 1992, 267, 15542-15548.

478. Arora, N.; Leppla, S.H. Residues 1-254 of anthrax toxin lethal factor are sufficient to cause cellular uptake of fused polypeptides. J. Biol. Chem. 1993, 268, 3334-3341.

479. Milne, J.C.; Blanke, S.R.; Hanna, P.C.; Collier, R.J. Protective antigen-binding domain of anthrax lethal factor mediates translocation of a heterologous protein fused to its amino- or carboxy-terminus. Mol. Microbiol. 1995, 15, 661-666.

480. Davies, H.; Bignell, G.R.; Cox, C.; Stephens, P.; Edkins, S.; Clegg, S.; Teague, J.; Woffendin, H.; Garnett, M.J.; Bottomley, W.; Davis, N.; Dicks, E.; Ewing, R.; Floyd, Y.; Gray, K.; Hall, S.; Hawes, R.; Hughes, J.; Kosmidou, V.; Menzies, A.; Mould, C.; Parker, A.; Stevens, C.; Watt, S.; Hooper, S.; Wilson, R.; Jayatilake, H.; Gusterson, B.A.; Cooper, C.; Shipley, J.; Hargrave, D.; Pritchard-Jones, K.; Maitland, N.; Chenevix-Trench, G.; Riggins, G.J.; Bigner, D.D.; Palmieri, G.; Cossu, A.; Flanagan, A.; Nicholson, A.; Ho, J.W.C.; Leung, S.Y.; Yuen, S.T.; Weber, B.L.; Seigler, H.F.; Darrow, T.L.; Paterson, H.; Marais, R.; Marshall, C.J.; Wooster, R.; Stratton, M.R.; Futreal, P.A. Mutations of the BRAF gene in human cancer. Nature 2002, 417, 949-954.

481. Koo, H.M.; VanBrocklin, M.; McWilliams, M.J.; Leppla, S.H.; Duesbery, N.S.; Woude, G.F. Apoptosis and melanogenesis in human melanoma cells induced by anthrax lethal factor inactivation of mitogen-activated protein kinase kinase. Proc. Natl. Acad. Sci. USA 2002, 99, 3052-3057.

482. Sebolt-Leopold, J.S.; Herrera, R. Targeting the mitogen-activated protein kinase cascade to treat cancer. Nat. Rev. Canc. 2004, 4, 937-947.

483. Abi-Habib, R.J.; Urieto, J.O.; Liu, S.; Leppla, S.H.; Duesbery, N.S.; Frankel, A.E. BRAF status and mitogen-activated protein/extracellular signal-regulated kinase kinase $1 / 2$ activity indicate sensitivity of melanoma cells to anthrax lethal toxin. Mol. Canc. Ther. 2005, 4, 1303-1310.

484. Abi-Habib, R.J.; Singh, R.; Leppla, S.H.; Greene, J.J.; Ding, Y.; Berghuis, B.; Duesbery, N.S.; Frankel, A.E. Systemic anthrax lethal toxin therapy produces regressions of subcutaneous human melanoma tumors in athymic nude mice. Clin. Canc. Res. 2006, 12, 7437-7443.

485. Moayeri, M.; Haines, D.; Young, H.A.; Leppla, S.H. Bacillus anthracis lethal toxin induces TNF-alpha-independent hypoxia-mediated toxicity in mice. J. Clin. Invest. 2003, 112, 670-682. 
486. Turpeenniemi-Hujanen, T. Gelatinases (MMP-2 and -9) and their natural inhibitors as prognostic indicators in solid cancers. Biochimie 2010, 87, 287-297.

487. Kurizaki, T.; Toi, M.; Tominaga, T. Relationship between matrix metalloproteinase expression and tumor angiogenesis in human breast carcinoma. Oncol. Rep. 1998, 5, 673-677.

488. Rundhaug, J.E. Matrix Metalloproteinases, Angiogenesis, and Cancer. Clin. Canc. Res. 2003, 9 , 551-554.

489. Rundhaug, J.E. Matrix metalloproteinases and angiogenesis. J. Cell. Mol. Med. 2005, 9, 267-285.

490. Alfano, R.W.; Leppla, S.H.; Liu, S.; Bugge, T.H.; Duesbery, N.S.; Frankel, A.E. Potent inhibition of tumor angiogenesis by the matrix metalloproteinase-activated anthrax lethal toxin: Implications for broad anti-tumor efficacy. Cell Cycle 2008, 7, 745-749.

491. Syrovets, T.; Simmet, T. Novel aspects and new roles for the serine protease plasmin. Cell. Mol. Life Sci. 2004, 61, 873-885.

492. Petersen, L.C. Kinetics of reciprocal pro-urokinase/plasminogen activation-Stimulation by a template formed by the urokinase receptor bound to poly(D-lysine). Eur. J. Biochem. 1997, 245, 316-323.

493. Duffy, M.J.; Duggan, C. The urokinase plasminogen activator system: A rich source of tumour markers for the individualised management of patients with cancer. Clin. Biochem. 2004, 37, 541-548.

494. Kilpatrick, L.M.; Harris, R.L.; Owen, K.A.; Bass, R.; Ghorayeb, C.; Bar-Or, A.; Ellis, V. Initiation of plasminogen activation on the surface of monocytes expressing the type II transmembrane serine protease matriptase. Blood 2006, 108, 2616-2623.

495. Moran, P.; Li, W.; Fan, B.; Vij, R.; Eigenbrot, C.; Kirchhofer, D. Pro-urokinase-type plasminogen activator is a substrate for hepsin. J. Biol. Chem. 2006, 281, 30439-30446.

496. McMahon, B.; Kwaan, H.C. The plasminogen activator system and cancer. Pathophysiol. Haemost. Thromb. 2008, 36, 184-194.

497. Andronicos, N.M.; Chen, E.I.; Baik, N.; Bai, H.; Parmer, C.M.; Kiosses, W.B.; Kamps, M.P.; Yates, J.R.; III; Parmer, R.J.; Miles, L.A. Proteomics-based discovery of a novel, structurally unique, and developmentally regulated plasminogen receptor, Plg-RKT, a major regulator of cell surface plasminogen activation. Blood 2010, 115, 1319-1330.

498. Strickland, D.K. A new plasminogen receptor. Blood 2010, 115, 1315-1316.

499. Andreasen, P.A.; Egelund, R.; Petersen, H.H. The plasminogen activation system in tumor growth, invasion, and metastasis. Cell. Mol. Life. Sci. 2000, 57, 25-40.

500. Dass, K.; Ahmad, A.; Azmi, A.S.; Sarkar, S.H.; Sarkar, F.H. Evolving role of uPA/uPAR system in human cancers. Canc. Treat. Rev. 2008, 34, 122-136.

501. Cunningham, K.; Lacy, D.B.; Mogridge, J.; Collier, R.J. Mapping the lethal factor and edema factor binding sites on oligomeric anthrax protective antigen. Proc. Nat.l Acad. Sci. USA 2002, 99, 7049-7053.

502. Mogridge, J.; Cunningham, K.; Lacy, D.B.; Mourez, M.; Collier, R.J. The lethal and edema factors of anthrax toxin bind only to oligomeric forms of the protective antigen. Proc. Natl. Acad. Sci. USA 2002, 99, 7045-7048. 
503. Patick, A.K.; Potts, K.E. Protease inhibitors as antiviral agents. Clin. Microbiol. Rev. 1998, 11, $614-627$.

504. Tong, L. Viral proteases. Chem. Rev. 2002, 102, 4609-4626.

505. Hsu, J.T.; Wang, H.C.; Chen, G.W.; Shih, S.R. Antiviral drug discovery targeting to viral proteases. Curr. pharm. Des. 2006, 12, 1301-1314.

506. Varshavsky, A. The N-end rule. Cold Spring Harb. Symp. Quant. Biol. 1995, 60, 461-478.

507. Varshavsky, A. The N-end rule: Functions, mysteries, uses. Proc. Natl. Acad. Sci. USA 1996, 93 , 12142-12149.

508. Varshavsky, A. The N-end rule pathway of protein degradation. Genes Cells 1997, 2, 13-28.

509. Varshavsky, A. The N-end rule and regulation of apoptosis. Nat. Cell Biol. 2003, 5, 373-376.

510. Mogk, A.; Schmidt, R.; Bukau, B. The N-end rule pathway for regulated proteolysis: Prokaryotic and eukaryotic strategies. Trends Cell Biol. 2007, 17, 165-172.

511. Ravid, T.; Hochstrasser, M. Diversity of degradation signals in the ubiquitin-proteasome system. Nat. Rev. Mol. Cell. Biol. 2008, 9, 679-689.

512. Falnes, P.O.; Olsnes, S. Modulation of the intracellular stability and toxicity of diphtheria toxin through degradation by the N-end rule pathway. EMBO J. 1998, 17, 615-625.

513. Wesche, J.; Elliott, J.L.; Falnes, P.O.; Olsnes, S.; Collier, R.J. Characterization of Membrane Translocation by Anthrax Protective Antigen. Biochemistry 1998, 37, 15737-15746.

514. Kaplan, A.H.; Swanstrom, R. Human immunodeficiency virus type 1 Gag proteins are processed in two cellular compartments. Proc. Natl .Acad. Sci. USA 1991, 88, 4528-4532.

515. Riviere, Y.; Blank, V.; Kourilsky, P.; Israel, A. Processing of the precursor of NF-kappa B by the HIV-1 protease during acute infection. Nature 1991, 350, 625-626.

516. Adams, L.D.; Tomasselli, A.G.; Robbins, P.; Moss, B.; Heinrikson, R.L. HIV-1 protease cleaves actin during acute infection of human T-lymphocytes. AIDS Res. Hum. Retroviruses 1992, 8, 291-295.

517. Konvalinka, J.; Litterst, M.A.; Welker, R.; Kottler, H.; Rippmann, F.; Heuser, A.M.; Krausslich, H.G. An active-site mutation in the human immunodeficiency virus type 1 proteinase (PR) causes reduced PR activity and loss of PR-mediated cytotoxicity without apparent effect on virus maturation and infectivity. J. Virol. 1995, 69, 7180-7186.

518. Nie, Z.; Bren, G.D.; Vlahakis, S.R.; Schimnich, A.A.; Brenchley, J.M.; Trushin, S.A.; Warren, S.; Schnepple, D.J.; Kovacs, C.M.; Loutfy, M.R.; Douek, D.C.; Badley, A.D. Human immunodeficiency virus type 1 protease cleaves procaspase 8 in vivo. J. Virol. 2007, 81, 6947-6956.

519. Gump, J.M.; Dowdy, S.F. TAT transduction: The molecular mechanism and therapeutic prospects. Trends Mol. Med. 2007, 13, 443-448.

520. Frankel, A.E.; Tagge, E.P.; Willingham, M.C. Clinical trials of targeted toxins. Semin. Canc. Biol. 1995, 6, 307-317.

521. Baluna, R.; Vitetta, E.S. Vascular leak syndrome: A side effect of immunotherapy. Immunopharmacology 1997, 37, 117-132.

522. Baluna, R.; Rizo, J.; Gordon, B.E.; Ghetie, V.; Vitetta, E.S. Evidence for a structural motif in toxins and interleukin-2 that may be responsible for binding to endothelial cells and initiating vascular leak syndrome. Proc. Natl. Acad. Sci. USA 1999, 96, 3957-3962. 
523. Kreitman, R.J. Taming ricin toxin. Nat. Biotech. 2003, 21, 372-374.

524. Smallshaw, J.E.; Ghetie, V.; Rizo, J.; Fulmer, J.R.; Trahan, L.L.; Ghetie, M.-A.; Vitetta, E.S. Genetic engineering of an immunotoxin to eliminate pulmonary vascular leak in mice. Nat. Biotech. 2003, 21, 387-391.

525. Zhang, Q.; Chen, G.; Liu, X.; Qian, Q. Monoclonal antibodies as therapeutic agents in oncology and antibody gene therapy. Cell Res. 2007, 17, 89-99.

526. da Silva, F.A.; Corte-Real, S.; Goncalves, J., Recombinant Antibodies as Therapeutic Agents: Pathways for Modeling New Biodrugs. BioDrugs 2008, 22, 301-314.

527. Tsutsumi, Y.; Onda, M.; Nagata, S.; Lee, B.; Kreitman, R.J.; Pastan, I. Site-specific chemical modification with polyethylene glycol of recombinant immunotoxin anti-Tac(Fv)-PE38 (LMB-2) improves antitumor activity and reduces animal toxicity and immunogenicity. Proc. Natl. Acad. Sci. USA 2000, 97, 8548-8553.

528. Hu, R.-G.; Zhai, Q.-W.; He, W.-J.; Mei, L.; Liu, W.-Y. Bioactivities of ricin retained and its immunoreactivity to anti-ricin polyclonal antibodies alleviated through pegylation. Int. J. Biochem. Cell Biol. 2002, 34, 396-402.

529. Filpula, D.; Yang, K.; Basu, A.; Hassan, R.; Xiang, L.; Zhang, Z.; Wang, M.; Wang, Q.-c.; Ho, M.; Beers, R.; Zhao, H.; Peng, P.; Zhou, J.; Li, X.; Petti, G.; Janjua, A.; Liu, J.; Wu, D.; Yu, D.; Zhang, Z.; Longley, C.; FitzGerald, D.; Kreitman, R.J.; Pastan, I. Releasable PEGylation of Mesothelin Targeted Immunotoxin SS1P Achieves Single Dosage Complete Regression of a Human Carcinoma in Mice. Bioconjug. Chem. 2007, 18, 773-784.

530. Pai, L.H.; FitzGerald, D.J.; Tepper, M.; Schacter, B.; Spitalny, G.; Pastan, I. Inhibition of Antibody Response to Pseudomonas Exotoxin and an Immunotoxin Containing Pseudomonas Exotoxin by 15-Deoxyspergualin in Mice. Canc. Res. 1990, 50, 7750-7753.

531. Siegall, C.B.; Haggerty, H.G.; Warner, G.L.; Chace, D.; Mixan, B.; Linsley, P.S.; Davidson, T. Prevention of immunotoxin-induced immunogenicity by coadministration with CTLA4Ig enhances antitumor efficacy. J. Immunol. 1997, 159, 5168-5173.

532. Gelber, E.E.; Vitetta, E.S. Effect of immunosuppressive agents on the immunogenicity and efficacy of an immunotoxin in mice. Clin. Canc. Res. 1998, 4, 1297-1304.

533. Onda, M.; Nagata, S.; FitzGerald, D.J.; Beers, R.; Fisher, R.J.; Vincent, J.J.; Lee, B.; Nakamura, M.; Hwang, J.; Kreitman, R.J.; Hassan, R.; Pastan, I. Characterization of the B cell epitopes associated with a truncated form of Pseudomonas exotoxin (PE38) used to make immunotoxins for the treatment of cancer patients. J. Immunol. 2006, 177, 8822-8834.

534. Onda, M.; Beers, R.; Xiang, L.; Nagata, S.; Wang, Q.C.; Pastan, I. An immunotoxin with greatly reduced immunogenicity by identification and removal of B cell epitopes. Proc. Natl. Acad. Sci. USA 2008, 105, 11311-11316.

535. Stish, B.J.; Oh, S.; Chen, H.; Dudek, A.Z.; Kratzke, R.A.; Vallera, D.A. Design and modification of EGF4KDEL 7Mut, a novel bispecific ligand-directed toxin, with decreased immunogenicity and potent anti-mesothelioma activity. Br. J. Canc. 2009, 101, 1114-1123.

(C) 2010 by the authors; licensee MDPI, Basel, Switzerland. This article is an open access article distributed under the terms and conditions of the Creative Commons Attribution license (http://creativecommons.org/licenses/by/3.0/). 